\title{
Primates in Peril: The World's 25 Most Endangered Primates, 2006-2008
}

Russell A. Mittermeier ${ }^{1}$, Jonah Ratsimbazafy ${ }^{2}$, Anthony B. Rylands ${ }^{3}$, Liz Williamson ${ }^{4}$, John F. Oates ${ }^{5}$, David Mbora $^{6}$, Jörg U. Ganzhorn ${ }^{7}$, Ernesto Rodríguez-Luna ${ }^{8}$, Erwin Palacios ${ }^{9}$, Eckhard W. Heymann ${ }^{10}$, M. Cecília M. Kierulff ${ }^{11}$, Long Yongcheng ${ }^{12}$, Jatna Supriatna ${ }^{13}$, Christian Roos ${ }^{14}$, Sally Walker ${ }^{15}$, and John M. Aguiar ${ }^{3}$

\author{
${ }^{1}$ Conservation International, Arlington, VA, USA \\ ${ }^{2}$ Durrell Wildife Conservation Trust - Madagascar Programme, Antananarivo, Madagascar \\ ${ }^{3}$ Center for Applied Biodiversity Science, Conservation International, Arlington, VA, USA \\ ${ }^{4}$ Department of Psychology, University of Stirling, Stirling, Scotland, UK \\ ${ }^{5}$ Department of Anthropology, Hunter College, City University of New York (CUNY), New York, USA \\ ${ }^{6}$ Department of Biological Sciences, Dartmouth College, Hanover, NH, USA \\ ${ }^{7}$ Institute of Zoology, Ecology and Conservation, Hamburg, Germany \\ ${ }^{8}$ Instituto de Neuroetología, Universidad Veracruzana, Veracruz, México \\ ${ }^{9}$ Conservation International Colombia, Bogotá, DC, Colombia \\ ${ }^{10}$ Abteilung Verhaltensforschung \& Ökologie, Deutsches Primatenzentrum, Göttingen, Germany \\ ${ }^{11}$ Fundação Parque Zoológico de São Paulo, São Paulo, Brazil \\ ${ }^{12}$ The Nature Conservancy, China Program, Kunming, Yunnan, China \\ ${ }^{13}$ Conservation International Indonesia, Jakarta, Indonesia \\ ${ }^{14}$ Gene Bank of Primates, Deutsches Primatenzentrum, Göttingen, Germany \\ ${ }^{15}$ Zoo Outreach Organisation, Coimbatore, Tamil Nadu, India
}

\section{Introduction}

Here we report on the fourth iteration of the biennial listing of a consensus of 25 primate species considered to be amongst the most endangered worldwide and the most in need of urgent conservation measures. The first was drawn up in 2000 by the IUCN/SSC Primate Specialist Group, together with Conservation International (Mittermeier et al. 2000). The list was subsequently reviewed and updated in 2002 during an open meeting held during the 19th Congress of the International Primatological Society (IPS) in Beijing, China (Mittermeier et al. 2002). That occasion provided for debate

With contributions from: Simon K. Bearder, Warren Y. Brockelman, Thomas M. Butynski, Bosco P. L. Chan, Mathias Craul, Tim R. B. Davenport, Jinie Dela, Anneke M. DeLuycker, Carolyn L. Ehardt, Susie Ellis, John R. Fellowes, Jörg U. Ganzhorn, Ha Thang Long, Frank Hawkins, Eckhard W. Heymann, Paul E. Honess, Steig Johnson, William R. Konstant, Mark Leighton, Le Khac Quyet, David N. M. Mbora, W. Scott McGraw, David Meyers, Pierre Moisson, Sanjay Molur, Alan R. Mootnick, Alba Lucia Morales-Jiménez, Bethan Morgan, Tilo Nadler, K. Anna I. Nekaris, John F. Oates, Gillian L. Olivieri, Lisa M. Paciulli, Erwin Palacios, Erik R. Patel, Andrew Perkin, Phan Duy Thuc, Guy H. Randriatahina, Noel Rowe, Agus Salim, Christoph Schwitzer, Nora Schwitzer, Myron Shekelle, Ian Singleton, Roswitha Stenke, Jacqui L. Sunderland-Groves, Thomas T. Struhsaker, Diego Tirira, Sally Walker, and Xiaoming Wang. among primatologists working in the field who had first-hand knowledge of the causes of threats to primates, both in general and in particular with the species or communities they study. The meeting and the review of the list of the World's 25 Most Endangered Primates resulted in its official endorsement by the IPS, and became as such a combined endeavor of the Primate Specialist Group, the IPS, and Conservation International. A third revision was carried out at a meeting in August 2004, at the 20th Congress of the IPS in Torino, Italy (Mittermeier et al. 2006). The list presented here, covering the biennium 2006-2008, is the result of a meeting held during the 21st Congress of the International Primatological Society (IPS), in Entebbe, Uganda, 26-30 June 2006. Our sincere thanks to William Olupot, the organizer of the congress, for making the arrangements.

As was the case for the 2004-2006 report, the texts for each species - reporting on their conservation status and threats - have counted on the extraordinary collaboration and expertise of those who know most about them. We are most grateful indeed for their time and dedication. Their contributions guarantee the authority of this report in describing the reasons why these primates are in such danger, and we hope it will be effective in drawing attention to the plight of each and in garnering support for the appropriate concern and action by those who can contribute to saving them, besides those whose moral obligation it is to do so. 
Mittermeier, R. A., W. R. Konstant and A. B. Rylands. 2000. The world's top 25 most endangered primates. Neotropical Primates 8(1): 49.

Mittermeier, R. A., W. R. Konstant, A. B. Rylands, T. M. Butynski, A. A. Eudey, J. U. Ganzhorn and R. Kormos. 2002. The world's top 25 most endangered primates 2002. Neotropical Primates 10(3): 128-131. Reprinted in Lemur News (8): 6-9.

Mittermeier, R. A., C. Valladares-Pádua, A. B. Rylands, A. A. Eudey, T. M. Butynski, J. U. Ganzhorn, R. Kormos, J. M. Aguiar and S. Walker. (eds.). 2006. Primates in Peril: The World's 25 Most Endangered Primates 2004-2006. Primate Conservation (20): 1-28.

\section{The World's 25 Most Endangered Primates: 2006-2008}

The 2006-2008 list of the World's 25 Most Endangered Primates has four species from Madagascar, seven from Africa, 11 from Asia, and three from the Neotropics - four lemurs, a galago and the kipunji from Tanzania, three red colobus monkeys, the roloway monkey, a tarsier and the pig-tailed langur from Indonesia, a slow loris from Sri Lanka, three langurs (two from Vietnam and one from Sri Lanka), two snub-nosed langurs (both from Vietnam), two spider monkeys from Colombia and Ecuador, the Peruvian yellow-tailed woolly monkey, two gibbons (China and India) and two of the great apes (the Sumatran orangutan and the Cross River gorilla from Nigeria and Cameroon) (Table 1).
Three species were returned to the list: The roloway guenon (Cercopithecus diana roloway) and Miss Waldron's red colobus (Procolobus badius waldroni), both previously on the 2002 list, and the Peruvian yellow-tailed woolly monkey (Oreonax flavicauda), which was on the first list in 2000.

The World's 25 Most Endangered Primates 2006-2008 are spread through 18 countries (Table 2). Those which stand out are: Madagascar (four species), Vietnam (four species), and Indonesia (three species). In the Neotropical Region, the three species are all Andean.

Four of the World's 25 Most Endangered Primates are species only recently described: The Sahamalaza Peninsula sportive lemur (Lepilemur sahamalazensis) was first described by Andriaholinirina and colleagues in 2006; the Rondo dwarf galago (Galagoides rondoensis) by Paul Honess in Kingdon (1997); the kipunji, a mangabey (Rungwecebus kipunji) by Ehardt and colleagues in 2005; and the grey-shanked douc (Pygathrix cinerea) by Nadler in 1997. A fifth, the tarsier of the Island of Siau, Indonesia, has yet to be described by Myron Shekelle and colleagues. Seventy-one primates have been described for the first time since 1990; 42 of them in Madagascar, another 14 from Africa and Asia, and 15 from the Neotropics. Many of these new primates have very restricted distributions (the reason they were not discovered before) and, some are known only from their type localities. With more information becoming available it is possible to predict that many will be future candidates for this list.

Table 1. The World's 25 Most Endangered Primates 2006-2008.

\begin{tabular}{|c|c|c|c|}
\hline \multirow[b]{2}{*}{1} & \multicolumn{3}{|l|}{ Madagascar } \\
\hline & Prolemur simus & Greater bamboo lemur & Madagascar \\
\hline 2 & Eulemur albocollaris & White-collared lemur & Madagascar \\
\hline 3 & Propithecus candidus & Silky sifaka & Madagascar \\
\hline \multirow[t]{2}{*}{4} & Lepilemur sahamalazensis & Sahamalaza Peninsula sportive lemur & Madagascar \\
\hline & \multicolumn{3}{|l|}{ Africa } \\
\hline 1 & Galagoides rondoensis & Rondo dwarf galago & Tanzania \\
\hline 2 & Cercopithecus diana roloway & Roloway monkey & Côte d'Ivoire, Ghana \\
\hline 3 & Procolobus pennantii pennantii & Pennant's red colobus & Equatorial Guinea (Bioko Is.) \\
\hline 4 & Procolobus rufomitratus & Tana River red colobus & Kenya \\
\hline 5 & Procolobus badius waldroni & Miss Waldron's red colobus & Côte d'Ivoire, Ghana \\
\hline 6 & Rungwecebus kipunji & Kipunji & Tanzania \\
\hline \multirow[t]{2}{*}{7} & Gorilla gorilla diehli & Cross River gorilla & Cameroon, Nigeria \\
\hline & \multicolumn{3}{|l|}{ Asia } \\
\hline 1 & Tarsius sp. & Siau Island tarsier & Indonesia (Siau Is.) \\
\hline 2 & Loris tardigradus nycticeboides & Horton Plains slender loris & Sri Lanka \\
\hline 3 & Simias concolor & Pig-tailed langur & Indonesia (Mentawai Is.) \\
\hline 4 & Trachypithecus delacouri & Delacour's langur & Vietnam \\
\hline 5 & Trachypithecus p. poliocephalus & Golden-headed langur or Cat Ba langur & Vietnam \\
\hline 6 & Semnopithecus vetulus nestor & Western purple-faced langur & Sri Lanka \\
\hline 7 & Pygathrix cinerea & Grey-shanked douc & Vietnam \\
\hline 8 & Rhinopithecus avunculus & Tonkin snub-nosed monkey & Vietnam \\
\hline 9 & Nomascus hainanus & Hainan black-crested gibbon & China (Hainan Is.) \\
\hline 10 & Hoolock hoolock & Western Hoolock gibbon & Bangladesh, India, Myanmar \\
\hline \multirow[t]{2}{*}{11} & Pongo abelii & Sumatran orangutan & Indonesia (Sumatra) \\
\hline & \multicolumn{3}{|l|}{ Neotropics } \\
\hline 1 & Ateles hybridus & Variegated spider monkey & Colombia, Venezuela \\
\hline 2 & Ateles fusciceps & Brown-headed spider monkey & Colombia, Ecuador \\
\hline 3 & Oreonax flavicauda & Peruvian yellow-tailed woolly monkey & Peru \\
\hline
\end{tabular}




\section{Changes in the List}

The nine primates lost from the 2004-2006 list, were substituted by six which had never before been include amongst the World's 25 Most Endangered, and three which had been listed in previous years. The reasons why species were removed from the list differ. In the case of the Eastern gorillas and the Neotropical species considerable attention is being given to their plight and conservation measures - research, distribution and status surveys, evaluation and mitigation measures for threats, creation and management of protected areas, environmental awareness and community programs - are underway to the extent that some guarantees are evident for their survival in the short- to midterm. There are three species which have coincident ranges in West Africa (Côte d'Ivoire and Ghana), and each jockeys for the position of the flagship-Miss Waldron's red colobus, the white-naped mangabey and the roloway guenon. In 2004-2006, the white-naped managabey was the one, in $2006-2008$ it was the turn of the roloway guenon. They both call for urgent measures to protect their remaining forests and populations. Miss Waldron's red colobus was brought back onto the list (previously 2002-2004). Its extinction was even reported in 2000, but hope lingers on with rare signs and reports that there are some still living. Repeated efforts since 2000 , however, have still failed to find any in the wild. It is significant that there are three red colobus monkeys on the 2006-2008 list - there could (should) undoubtedly be more. Distribution and population surveys and genetic studies are providing new information to help us clarify the complex taxonomy and poorly known ranges of the red colobus monkeys, and it is becoming increasingly evident that many are in very serious difficulties. The red colobus monkeys are uncommonly susceptible to hunting and forest loss, and listing three

Table 2. The distribution by country of the the World's 25 Most Endangered Primates 2006-2008.

\begin{tabular}{|c|c|}
\hline \multicolumn{2}{|l|}{ Madagascar } \\
\hline Madagascar & Prolemur simus, Eulemur albocollaris, Propithecus candidus, Lepilemur sahamalazensis \\
\hline \multicolumn{2}{|l|}{ Africa } \\
\hline Cameroon & Gorilla gorilla diehli \\
\hline Côte d'Ivoire & Cercopithecus diana roloway, Procolobus badius waldroni \\
\hline Equatorial Guinea & Procolobus pennantii pennantii \\
\hline Ghana & Cercopithecus diana roloway, Procolobus badius waldroni \\
\hline Kenya & Procolobus rufomitratus \\
\hline Nigeria & Gorilla gorilla diehli \\
\hline Tanzania & Galagoides rondoensis, Rungwecebus kipunji \\
\hline \multicolumn{2}{|r|}{ ( } \\
\hline Bangladesh & Hoolock hoolock \\
\hline China & Nomascus hainanus \\
\hline India & Hoolock hoolock \\
\hline Indonesia & Tarsius sp. (Siau Island), Simias concolor, Pongo abelii \\
\hline Myanmar & Hoolock hoolock \\
\hline Sri Lanka & Loris tardigradus nycticeboides, Semnopithecus vetulus nestor \\
\hline Vietnam & Trachypithecus delacouri, Trachypithecus p .poliocephalus, Pygathrix cinerea, Rhinopithecus avunculus \\
\hline \multicolumn{2}{|l|}{ Neotropical Region } \\
\hline Colombia & Ateles fusciceps, Ateles hybridus \\
\hline Venezuela & Ateles hybridus \\
\hline Ecuador & Ateles fusciceps \\
\hline
\end{tabular}

Table 3. Primates on the 2004-2006 list of the world's 25 most endangered primates that were removed from the 2006-2008 list.

\begin{tabular}{l|l}
\hline Madagascar & \\
\hline Propithecus perrieri & Perrier's sifaka \\
\hline Galagoides sp. & Mt. Rungwe galago \\
\hline Africa & \\
\hline Cercocebus atys lunulatus & White-naped mangabey \\
\hline Cercocebus sanjei & Sanje mangabey \\
\hline Gorilla beringei & Eastern gorillas \\
\hline Asia & \\
\hline Presbytis hosei canicrus & Miller's grizzled surili \\
\hline Neotropics & \\
\hline Leontopithecus caissara & Black-faced lion tamarin \\
\hline Cebus xanthosternos & Buffy-headed tufted capuchin \\
\hline Brachyteles hypoxanthus & Northern muriqui \\
\hline
\end{tabular}

Table 4. The six primates appearing on the list of the world's 25 most endangered primates for the first time, 2006-2008.

\begin{tabular}{l|l}
\hline Madagascar & \\
\hline Lepilemur sahamalazensis & Sahamalaza Peninsula sportive lemur \\
\hline Africa & \\
\hline Galagoides rondoensis & Rondo dwarf galago \\
\hline Rungwecebus kipunji & Kipunji \\
\hline Asia & \\
\hline Tarsius sp. & Siau Island tarsier \\
\hline Hoolock hoolock & Western Hoolock gibbon \\
\hline Neotropical Region & \\
\hline Ateles fusciceps & Brown-headed spider monkey \\
\hline
\end{tabular}


of them here signals the need for further research and urgent conservation measures for the entire genus.

In the case of the Mt. Rungwe galago, its listing in 2004 resulted in distribution and status surveys that have indicated that it is less threatened than the Rondo dwarf galago to which its place was given. The listing of Perrier's sifaka was given over to the Sahamalaza Peninsula sportive lemur, serving as a representative of the possible and usually probable plight of many of the numerous lemurs described for the first time over the last two years - known only from single localities or desperately small forest patches. The kipunji, a dramatic find in Tanzania in 2003, is known from just two localities. Their populations are small and fragmented, and the place of this mangabey on the 2006 list was ceded by the Sanje River mangabey, which has been receiving increasing and promising attention for the protection of its populations and forests.

Many of the Asian langurs are now severely threatened, not only from subsistence hunting and habitat loss, but also from hunting for body parts and tissues to satisfy the insatiable demands of the Asian peoples for exotic dishes and concoctions of wild animals, for amulets, remedies and aphrodisiacs. Six of the Asian colobines are on this 2006-2008 list, and Miller's grizzled surili was an ephemeral representative of so many others which should also be highlighted. It is significant that 11 of the 25 Most Endangered Primates are from Asia. A list of the most threatened primates in Asia could easily reach 50, all as threatened as any on this list of the World's 25 Most Endangered.

Table 5 shows the four lists produced to date. Eight species have remained on the list since 2000: the silky sifaka (Propithecus candidus), four Asian colobines - Delacour's langur (Trachypithecus delacouri), the golden-headed or Cat Ba langur (T. p. poliocephalus), the grey-shanked douc (Pygathrix cinerea), and the Tonkin snub-nosed monkey (Rhinopithecus avunculus) - the Hainan gibbon (Nomascus hainanus), the Cross River gorilla (Gorilla gorilla diehli), and the Sumatran orangutan (Pongo abelii).

\section{Madagascar}

\section{Greater Bamboo Lemur}

Prolemur simus (Gray, 1871)

Madagascar

(2002, 2004, 2006)

Formerly in the genus Hapalemur, Groves (2001) placed the greater bamboo lemur in the genus Prolemur based on a suite of distinctive dental and chromosomal characteristics (Vuillaume-Randriamanantena et al. 1985; Macedonia and Stanger 1994; Stanger-Hall 1997). As its common name implies, the greater bamboo lemur is the largest of Madagascar's bamboo-eating lemurs (Albrecht et al. 1990). Genetic studies further support its separation from the other bamboo lemurs and suggest that Hapalemur may, in fact, be more closely related to the genus Lemur (Rumpler et al. 1989; Macedonia and Stanger 1994; Stanger-Hall 1997). Historical records (Schwarz 1931) and sub-fossil remains confirm that it was once widespread throughout the island (Godfrey and Vuillaume-Randriamanantena 1986; Wilson et al. 1988; Godfrey et al. 1999). Documented populations are very patchily distributed and restricted to the south-central portion of the country's eastern rain forests, including those of Kianjavato, Ranomafana and Andringitra National Parks (and the corridor between them), Evendra (near Ivato, southeast of Andringitra), Karianga (near Vondrozo), and possibly the forest fragments south of Ifanadiana (Meier and Rumpler 1987; Wright et al. 1987; Sterling and Ramaroson 1996; Goodman et al. 2001b; Irwin et al. 2005). Recent unpublished reports also indicate its presence in the forests of Karianga, northwest of Manombo (E. E. Louis Jr. pers. comm.) and north up to the region of Moramanga (Dolch et al. 2004; Rakotosamimanana et al. 2004). Shoots, young and mature leaves, and pith of the bamboo Cathariostachys madagascariensis can account for as much as $95 \%$ of the diet (Tan 1999, 2000). Other food items include flowers of the traveler's palm (Ravenala madagascariensis), and fruits of Artocarpus integrifolia, Ficus spp. and Dypsis spp., and leaves of Pennisetum clandestinum (Meier and Rumpler 1987). Observations of animals in the wild and captivity suggest that $P$. simus is cathemeral (Santini-Palka 1994; Tan 1999, 2000). They live in polygynous groups of seven to 11 animals occupying home ranges of 60 ha or more (Sterling and Ramaroson 1996; Tan 1999, 2000). The greater bamboo lemur is threatened by slash-and-burn agriculture, illegal logging, the cutting of bamboo, and hunting with slingshots (Meier 1987; Meier and Rumpler 1987). It has vanished from most of its former range and only a few relatively small populations have been documented thus far in the southeast. Hunting and habitat destruction are the presumed causes. It occurs in the national parks of Ranomafana and Andringitra (although limited by suitable microhabitat within these protected areas). The population in Ranomafana National Park is estimated at no more than 250 adult individuals (P. C. Wright pers. comm.). Opportunities exist to extend protection to lemur populations in neighboring forests, as well as to develop a fairly long corridor of protected forests between Ranomafana and Andringitra, within which it is presumed other greater bamboo lemur populations will be found.

Jörg U. Ganzhorn \& Steig Johnson

\section{White-collared Lemur}

Eulemur albocollaris (Rumpler, 1975)

Madagascar

(2004, 2006)

The white-collared lemur was formerly classed as a subspecies of Eulemur fulvus (Tattersall 1982; Mittermeier et al. 1994; Pastorini et al. 2000). Recent cytogenetic and molecular genetic analyses support full species status for Eulemur albocollaris (Djletati et al. 1997; Wyner et al. 1999), despite natural hybridization between this taxon and Eulemur f. rufus (Sterling and Ramarason 1996; Johnson and Wyner 2000; Wyner et al. 2002). The white-collared lemur has one of the most restricted ranges of any Eulemur species, occurring only in southeastern Madagascar in a thin strip of rain forest that 
The world's 25 most endangered primates

Table 5. The four lists of the World's 25 Most Endangered Primates produced to date. The eight species shaded are those which have remained on the list since 2000.

\begin{tabular}{|c|c|c|c|}
\hline 2000 & 2002 & 2004 & 2006 \\
\hline \multicolumn{4}{|l|}{ Madagascar } \\
\hline \multicolumn{4}{|l|}{ Hapalemur griseus alaotrensis } \\
\hline & & Eulemur albocollaris & Eulemur albocollaris \\
\hline & & & Lepilemur sahamalazensis \\
\hline Propithecus perrieri & Propithecus perrieri & Propithecus perrieri & \\
\hline \multicolumn{4}{|l|}{ Propithecus tattersalli } \\
\hline \multicolumn{4}{|l|}{ Africa } \\
\hline & & $\begin{array}{l}\text { Galagoides sp. } \\
\text { Mt. Rungwe galago }\end{array}$ & \\
\hline & & & Galagoides rondoensis \\
\hline & Cercopithecus diana roloway & & Cercopithecus diana roloway \\
\hline \multirow[t]{2}{*}{ Cercocebus atys lunulatus } & Cercocebus atys lunulatus & Cercocebus atys lunulatus & \\
\hline & & & Rungwecebus kipunji \\
\hline \multirow[t]{3}{*}{ Procolobus badius waldroni } & Procolobus badius waldroni & & Procolobus badius waldroni \\
\hline & & Procolobus pennantii pennantii & Procolobus pennantii pennantii \\
\hline & Procolobus rufomitratus & Procolobus rufomitratus & Procolobus rufomitratus \\
\hline Gorilla gorilla beringei & Gorilla beringei beringei & Gorilla beringei & \\
\hline Gorilla gorilla diehli & Gorilla gorilla diehli & Gorilla gorilla diehli & Gorilla gorilla diehli \\
\hline \multicolumn{4}{|l|}{ Asia } \\
\hline & & & Tarsius sp. (Siau Is.) \\
\hline & & Loris tardigradus nycticeboides & Loris tardigradus nycticeboides \\
\hline \multirow[t]{4}{*}{ Rhinopithecus avunculus } & Rhinopithecus avunculus & Rhinopithecus avunculus & Rhinopithecus avunculus \\
\hline & Rhinopithecus bieti & & \\
\hline & Rhinopithecus brelichi & & \\
\hline & & Semnopithecus vetulus nestor & Semnopithecus vetulus nestor \\
\hline \multicolumn{4}{|l|}{ Hylobates moloch } \\
\hline \multirow[t]{2}{*}{ Hylobates concolor hainanus } & Nomascus nasutus & Nomascus hainanus & Nomascus hainanus \\
\hline & & & Hoolock hoolock \\
\hline Pongo abelii & Pongo abelii & Pongo abelii & Pongo abelii \\
\hline \multicolumn{4}{|l|}{ Neotropics } \\
\hline \multicolumn{4}{|l|}{ Leontopithecus rosalia } \\
\hline \multicolumn{4}{|l|}{ Leontopithecus chrysopygus } \\
\hline Leontopithecus caissara & Leontopithecus caissara & Leontopithecus caissara & \\
\hline \multirow[t]{4}{*}{ Cebus xanthosternos } & Cebus xanthosternos & Cebus xanthosternos & \\
\hline & & & Ateles hybridus \\
\hline & & Ateles hybridus brunneus & \\
\hline & & & Ateles fusciceps \\
\hline Lagothrix flavicauda & & & Oreonax flavicauda \\
\hline Brachyteles hypoxanthus & Brachyteles hypoxanthus & Brachyteles hypoxanthus & \\
\hline
\end{tabular}


runs from just north of the Manampatrana River south to the Mananara River (Petter and Petter-Rousseaux 1979; Tattersall 1982; Irwin et al. 2005). The hybrid zone with E. f. rufus is centered on the headwaters region of the Manampatrana River in Andringitra National Park, extending south to the vicinity of Karianga and north to near Ankarimbelo (Irwin et al. 2005; S. Johnson unpublished data), and encompassing an area of up to $50 \%$ of the range of "pure" E. albocollaris. Two isolated populations also occur in the coastal fragments of Manombo Special Reserve and Mahabo Forest near Farafangana. Recent analyses combining ground surveys and Landsat imagery indicate that the total habitat remaining within this species' range is approximately $700 \mathrm{~km}^{2}$, with an estimated remaining population of 7,265 $\pm 2,268$ individuals (Irwin et al. 2005). Information regarding the natural history of this lemur comes largely from recent studies conducted at Vevembe Forest, with new long-term studies underway at Manombo and Mahabo.

The white-collared lemur has a largely frugivorous diet, supplemented with flowers, leaves, and fungi; Pandanus spp. flowers are an especially important food late in the dry season (Johnson 2002). The species is cathemeral (active both day and night) throughout the year. Social groups tend to be multi-male/multi-female and regularly exhibit fission-fusion. Selective logging, hunting and the conversion of its habitat to agricultural land are the greatest threats to the survival of the white-collared lemur. It is found in only two protected areas, the Andringitra National Park and Manombo Special Reserve, but the Andringitra population appears to be largely composed of hybrids (CBSG 2002; Wyner et al. 2002). Recent research has identified populations in unprotected forests (Vevembe, for example) that could be added to existing parks and reserves (Johnson and Overdorff 1999). The Missouri Botanical Garden is also presently active in managing and upgrading the protected status of the littoral forest of Mahabo. It should be noted that a possible third Eulemur species, E. cinereiceps, has been suggested to occur within or near the coastal portion of the range of E. albocollaris based on variant museum specimens and captive individuals (Groves 2001; Mittermeier et al. 2006). However, the weight of current evidence suggests this taxon is either synonymous with E. albocollaris or extinct. All surveyed remaining habitats appear to contain either E. albocollaris (Manombo and Mahabo, south of Farafangana) or are too small and/or disturbed to support Eulemur (for example, Analalava and Sakanany, north of Farafangana); however, exhaustive ground surveys and genetic sampling should be conducted in the region to confirm these findings.

Steig Johnson \& William R. Konstant

\section{Silky Sifaka}

Propithecus candidus Grandidier, 1871

Madagascar

(2000, 2002, 2004, 2006)

Propithecus candidus is a large, white, rainforest sifaka found only within a small section of northeastern Madagascar. Surveys for these highly social diurnal indriids suggest that they are patchily distributed and occur at low densities within just a few protected areas: Marojejy National Park, Anjanaharibe-Sud Special Reserve, and (very rarely) the Anjanaharibe and Manandriana portions of Makira Protected Area north of the Antainambalana River. They have been observed primarily in undisturbed forest (except for the Betaolana Corridor) between $700 \mathrm{~m}$ and 1,875 m above sea level (Tattersall 1982; Duckworth et al. 1995; Schmid and Smolker 1998; Sterling and McFadden 2000; Goodman et al. 2003; Rakotondratsimba et al. 2007). The behavior and ecology of this species is known mainly from a short study (Kelley and Mayor 2002) and a 14.5-month study at Marojejy National Park (Patel et al. 2005; Patel 2005, 2006, 2007, submitted).

The silky sifaka's diet is highly folivorous, including mature and young leaves. They also eat fruit, flowers, seeds, bark, soil, and roots. Silky sifakas are the flagship species of a newly proposed World Heritage Site (Marojejy National Park) and are the species that most tourists come to view. Their social structure appears variable (pair-living and polygynandrous), with group sizes ranging from 2 to 9 individuals. Home ranges can exceed 40 ha (Patel 2006). They inhabit several types of elevation-specific habitats including primary montane rainforest, sclerophyllous forest, and even low ericoid bush at their highest elevations (Goodman 2000). Their primary conservation threat appears to be hunting (Patel et al. 2005). Habitat disturbance, such as slash-and-burn agriculture ('tavy'), logging of precious woods (for example, rosewood) and fuel-wood, also occurs within and adjacent to the protected areas where they are found (Patel submitted). The remaining population may be as low as a few hundred individuals and is unlikely to be larger than a few thousand (Mittermeier et al. 2006).

Erik R. Patel, David Meyers \& Frank Hawkins

\section{Sahamalaza Sportive Lemur}

Lepilemur sahamalazensis Andriaholinirina et al., 2006 Madagascar

(2006)

The Sahamalaza sportive lemur (Lepilemur sahamalazensis) is one of the numerous lemurs recently described based on genetic and morphometric data (Andriaholinirina et al. 2006). Although the range of this medium-sized, nocturnal primate is not precisely known, it is thought to be strictly limited to the Sahamalaza Peninsula in northwestern Madagascar. The peninsula is part of a transition zone between the Sambirano region in the north and the western dry deciduous forest region in the south. The forests in this area contain a mixture of plant species typical of dry forest and some typical of the Sambirano domain (Birkinshaw 2004). Lepilemur sahamalazensis depends on these semi-humid forests, of which only a few fragments now remain. Very little is known about the ecology and behavior of the Sahamalaza sportive lemur. During preliminary night observations, individuals were mostly encountered alone or in groups of two. During the daytime, they were found sleeping in tree holes. This suggests that they have a social structure typical for the Lepilemur genus, i.e., pair-living animals defending exclusive territories. Encounter rate is high in the forest of Ankarafa (Olivieri et al. 2005). 
This could be due to recent loss of habitat, forcing all animals to concentrate in the few remaining forest fragments.

Total numbers are unknown but, taking into account the limited distribution of $L$. sahamalazensis and the small extent of remaining forest cover, they are probably in their low thousands. The species is present in the recently established Parc National de Sahamalaza - Iles Radama (Aire Protégée Terrestre, Marine et Côtière) which is part of the Malagasy protected area network managed through the Association Nationale pour la Gestion des Aires Protégées (ANGAP). The Sahamalaza Peninsula is also a UNESCO Biosphere Reserve (declared in 2001). Although the protected area probably covers the entire distribution of $L$. sahamalazensis, forest-clearing for agriculture, and timber-cutting for charcoal and construction continue at an alarming rate. Additionally, as is true for all sportive lemurs, it suffers from a high hunting pressure. These animals are easy and defenceless prey for hunters that find their sleeping sites during the day and cut the tree down or climb it to fetch them. Furthermore, traps are laid, harming not only L. sahamalazensis but also the Critically Endangered blue-eyed black lemur (Eulemur macaco flavifrons), which has a similar distribution.

The combination of a very limited range containing only little and rapidly decreasing suitable habitat with a high hunting pressure makes this species especially vulnerable. A consortium of the Association Européenne pour l'Etude et la Conservation des Lémuriens (AEECL), the Wildlife Conservation Society (WCS), ANGAP, and the local communities is currently establishing structures to ensure better protection of the few remaining forest fragments in the park (Schwitzer et al. 2006). Simultaneously, studies are under way to determine the exact distribution of $L$. sahamalazensis as well as the density and size of the remaining population.

Gillian L. Olivieri, Christoph Schwitzer, Nora Schwitzer, Mathias Craul \& Guy H. Randriatahina

\section{Africa}

\section{Rondo Dwarf Galago \\ Galagoides rondoensis (Honess in Kingdon, 1997) Tanzania \\ (2006)}

Weighing approximately $60 \mathrm{~g}$, this is the smallest of all galago species (Honess 1996b). It is distinct from other dwarf galagos in its diminutive size, a bottle-brush-shaped tail, its reproductive anatomy, and its distinctive "double unit rolling call" (Bearder et al. 1995; Honess 1996a, 1996b). Current knowledge indicates that this species occurs in two distinct areas, one in southwest Tanzania near the coastal towns of Lindi and Mtwara, the other approximately $400 \mathrm{~km}$ further north, above the Rufiji River, in pockets of forest around Dar es Salaam. One further population occurs in Sadaani National Park, approximately $100 \mathrm{~km}$ north of Dar es Salaam. Rondo dwarf galagos have a mixed diet of insects and fruit, often feed close to the ground, and move by vertical clinging and leaping in the shrubby understorey. They build daytime sleeping nests, which are often in the canopy (Bearder et al. 2003). As with many small primates, $G$. rondoensis is probably subject to predation from owls and other nocturnal predators. Among these, genets, palm civets and snakes are known to invoke intense episodes of alarm calling (Honess 1996b).

The IUCN Red List gives G. rondoensis as Endangered B2ab(i-v) (IUCN 2006). It has an extremely limited and fragmented range in a number of remnant patches of Eastern African Coastal Dry Forest (sensu Burgess and Clarke 2000 , p.18) in Tanzania, namely those at Zaraninge forest $\left(06^{\circ} 08^{\prime} \mathrm{S}, 38^{\circ} 38^{\prime} \mathrm{E}\right)$ in Sadaani National Park (Perkin 2000), Pande Game Reserve (GR) $\left(06^{\circ} 42^{\prime} \mathrm{S}, 39^{\circ} 05^{\prime} \mathrm{E}\right)$, Pugu/Kazimzumbwi $\left(06^{\circ} 54^{\prime} \mathrm{S}, 3^{\circ} 05^{\prime} \mathrm{E}\right)$ (Perkin 2003, 2004), Rondo $\left(10^{\circ} 08^{\prime} \mathrm{S}, 39^{\circ} 12^{\prime} \mathrm{E}\right)$, Litipo $\left(10^{\circ} 02^{\prime} \mathrm{S}, 39^{\circ} 29^{\prime} \mathrm{E}\right)$ and Ziwani $\left(10^{\circ} 20^{\prime} \mathrm{S}, 40^{\circ} 18^{\prime} \mathrm{E}\right)$ forest reserves (FR) (Honess 1996b; Honess and Bearder 1996). Specimens of G. rondoensis, originally described as Galagoides demidovii phasma, were collected by Ionides from Rondo Plateau in 1955, and Lumsden from Nambunga, near Kitangari, (approximately $10^{\circ} 40^{\prime} \mathrm{S}, 39^{\circ} 25^{\prime} \mathrm{E}$ ) on the Makonde Plateau in Newala District in 1953. Doubts surround the persistence of this species on the Makonde Plateau, which has been extensively cleared for agriculture. Surveys there in 1992 failed to detect any extant populations (Honess 1996b).

No detailed surveys have been conducted to assess population sizes of G. rondoensis. Limited distribution surveys have been conducted, however, in the southern (Honess 1996b) and northern coastal forests (27 surveyed) of Tanzania and coastal Kenya (seven surveyed) (Perkin 2000, 2003, 2004). Absolute population sizes remain undetermined but recent surveys have provided estimates of density (3-6/ha at Pande Game Reserve [Perkin 2003] and 8/ha at Pugu Forest Reserve [Perkin 2004]) and relative abundance from encounter rate $(3-10 / \mathrm{hr}$ at Pande Game Reserve and Pugu/Kazimzumbwi Forest Reserve [Perkin 2003, 2004] and 3.94/hr at Rondo Forest Reserve [Honess 1996b]). There is a clear and urgent need for further surveys to determine population sizes in these dwindling forest patches. The total area of forest in which G. rondoensis is currently known to occur does not exceed $92.6 \mathrm{~km}^{2}$ (Pande GR: $2.4 \mathrm{~km}^{2}$, Rondo FR: $25 \mathrm{~km}^{2}$, Ziwani FR: $7.7 \mathrm{~km}^{2}$, Pugu/Kazimzumbwi FR: $33.5 \mathrm{~km}^{2}$, Litipo FR: $4 \mathrm{~km}^{2}$ and Zaraninge forest: $20 \mathrm{~km}^{2}$ [Minimum area data source: Burgess and Clarke 2000; Doggart 2003]). The major threat facing this species is loss of habitat. All sites are subject to some level of agricultural encroachment, charcoal manufacture and/or logging. All sites, except Pande GR and Zaraninge forest, are national or local authority forest reserves and as such nominally, but in practice minimally, protected. Given current trends in charcoal production for nearby Dar es Salaam, the forest reserves of Pugu and Kazimzumbwi will disappear over the next $10-15$ years (Ahrends 2005). Pande, as a Game Reserve, is perhaps more secure, and Zareninge forest, being in a National Park, is the most protected part of the range of $G$. rondoensis. Conservation action is urgently needed, and more research is required to determine the continuing rate of habitat loss at these sites and to survey new areas for remnant populations. 
Across its known range, the Rondo galago can be found sympatric with a number of other galagos, including two much larger species in the genus Otolemur: Garnett's galago, $O$. garnettii, and the thick-tailed galago, $O$. crassicaudatus. The Rondo galago is sympatric with the Zanzibar galago, Galagoides zanzibaricus, in the northern parts of its range (for example, in Zaraninge forest, Pugu/Kazimzumbwi FR and Pande GR). G. zanzibaricus is classified as Lower Risk (Near Threatened) in the 2006 IUCN Red List (IUCN 2006) due to threats to its habitat. In the southern parts of its range (for example, at Rondo, Litipo and Ziwani FRs), the Rondo galago is sympatric with Grant's galago, Galagoides granti, which is listed as Data Deficient (IUCN 2006). The Mountain dwarf galago, Galagoides orinus, ranked as Data Deficient (IUCN 2006), is restricted to areas of sub-montane and montane forest in the Eastern Arc Mountains further inland in Tanzania. As such G. orinus also has a very restricted range, although areas of its preferred habitat are believed to be at less risk of degradation because they are relatively inaccessible.

\section{Paul E. Honess, Andrew Perkin \& Simon K. Bearder}

\section{Roloway Guenon}

Cercopithecus diana roloway (Schreber, 1774)

Ghana and Côte d'Ivoire

$(2002,2006)$

There are two subspecies of Cercopithecus diana, both highly attractive, arboreal monkeys that inhabit the Upper Guinean forests of West Africa (Grubb et al. 2003). The Roloway subspecies is distinguished by its broad white brow line, long white beard and yellow thighs. Groves (2001) considers the two subspecies to be sufficiently distinct to be regarded as full species. Of the two forms, the Roloway, which is known from Ghana and eastern Côte d'Ivoire, is more seriously threatened with extinction. In fact, along with the white-naped mangabey (Cercocebus atys lunulatus) and Miss Waldron's red colobus (Procolobus badius waldroni), it is among the three most endangered monkeys of the Upper Guinea forest block and a target species of the relentless bushmeat trade (Oates 1996).

As primatologists search the tropical forests of Ghana and Côte d'Ivoire for evidence of living red colobus, they are also documenting the continued decline of both the Roloway guenon and white-naped mangabey, which seem to be found in and to be absent from many of the same forests (Struhsaker and Oates 1995; Oates et al. 1996/1997; McGraw 1998a; Kone 2004; Oates 2006). In Ghana, Roloway guenons have been steadily extirpated from both unprotected and protected areas (for example, Bia National Park) and the monkey is nearing extinction in that country if it has not disappeared already. Very recent surveys failed to confirm the presence of Roloways in four reserves in western Ghana including one-Krokosua Hills Forest Reserve-believed to harbor the monkey only several years earlier (Magnuson 2003; Oates 2006). It is possible that Ankasa Resource Reserve still contains a few Roloway individuals (Magnuson 2003), but in 2006 a wildlife guard reported to J. Oates (unpublished) that he had not seen the monkey for several years. A thorough new survey of Ankasa, and of the Dadieso Forest Reserve (where the monkey was also reported in the recent past) should be a high priority.

In neighboring Côte d'Ivoire, the Roloway guenon is not known from any protected areas and the monkey's status is equally dire. Surveys made ten years ago documented Roloways in two forests: the Yaya Forest Reserve and wet forest adjacent to the Ehy Lagoon (McGraw 1998b, 2005). Field surveys made in 2004 failed to document Roloways at additional sites in southern Côte d'Ivoire (Kone and Akpatou 2005) although hunters indicate that Roloways are present in small numbers in the Parc National des Iles Ehotilé (Kone and Akpatou 2005). Intensive and systematic primate inventories must be carried out at both Ehotilé and Ehy.

W. Scott McGraw \& John F. Oates

\section{Pennant's Red Colobus}

Procolobus pennantii pennantii (Waterhouse, 1838)

Bioko Island, Equatorial Guinea

(2004, 2006)

The endangered Pennant's red colobus monkey Procolobus pennantii (Waterhouse, 1838) is presently regarded by the IUCN/SSC Primate Specialist Group as comprised of four subspecies, but their relationships within $P$. pennantii, and with other taxa of red colobus, need clarification (Groves 2001; Grubb et al. 2003). Future research may reveal that these four "subspecies" are better referred to as full species. $P$. pennantii takes its name from the form restricted to Bioko Island, Equatorial Guinea, P. pennantii pennantii. This endangered subspecies probably has the most restricted range of all of Bioko's 11 primates, and is now found only in a small part of the southwest of the island, within the Gran Caldera and Southern Highlands Scientific Reserve (51,000 ha). P. $p$. pennantii is threatened by bushmeat hunting, most notably since the early 1980's when a commercial bushmeat market appeared in the town of Malabo (Butynski and Koster 1994). Hearn et al. (2006) estimated numbers killed for bushmeat at 550 and 350 in the years 2004 and 2005, respectively, and a decline of more than $40 \%$ in the population over the 20 years from 1986 to 2006. The average price paid in the Malabo market for an adult $P$. pennantii in 2006 was about US $\$ 42$. This is well over twice as much as the cost of the readily available, high quality, whole chicken and beef at the same market. Similar high prices are paid on Bioko for all seven species of monkeys and for both species of duikers. Bushmeat on Bioko is, obviously, now a 'luxury food' (Hearn et al. 2006). Probably all of the P. pennantii killed on Bioko at this time are coming from within the Gran Caldera and Southern Highlands Scientific Reserve, but small numbers may persist in the most remote and rugged parts of Bioko's other protected area, the Pico Basile National Park $\left(330 \mathrm{~km}^{2}\right)$. The continued high flow of primates, duikers and other wildlife into 
the Malabo bushmeat market indicates that neither 'protected area' is receiving adequate protection from the government of Equatorial Guinea.

The other three subspecies are: the critically endangered Bouvier's red colobus P. p. bouvieri (Rochebrune, 1887) of east-central Republic of Congo; the endangered Niger Delta red colobus P. p. epieni Grubb and Powell, 1999, of Nigeria; and the endangered Preuss's red colobus $P$. $p$. preussi (Matschie, 1900) of southeastern Nigeria and western Cameroon (Oates 1994, 2000; Struhsaker 2005). P. p. pennantii and $P$. p. preussi are particularly distinct taxa in terms of their vocalizations, while the vocal repertoire of $P$. $p$. epieni most closely resembles those of the red colobus in central and eastern Africa (T. T. Struhsaker unpublished data).

To the northwest of the $P$. pennantii complex of subspecies occurs the critically endangered Miss Waldron's red colobus P. badius waldroni (Hayman, 1936) of southwestern Ghana and southeastern Côte d'Ivoire (Struhsaker 1999; Oates et al. 2000; Groves 2001; Grubb et al. 2003). All five of these subspecies are today close to extinction, with very restricted ranges and small numbers as a result of intensive hunting and extensive habitat degradation and loss (Wolfheim 1983; Oates 1994, 1996; Oates et al. 2000; Struhsaker 2005; Hearn et al. 2006). Neither P. p. bouvieri nor P. b. waldroni have been observed alive by scientists for at least 25 years, raising concerns that they may be extinct (see profile for Miss Waldron's red colobus in this report).

The red colobus monkeys of West Africa and west Central Africa are probably more threatened than any other taxonomic group of primates in Africa. This is partly due to the fact that red colobus are especially sensitive to habitat degradation and vulnerable to hunters (Oates 1996; Oates et al. 2000; Waltert et al. 2002; Struhsaker 2005). None of the few protected areas in which any of these five subspecies of red colobus occur is well protected (e.g., McGraw 1998). Of very high priority for the conservation of primate biodiversity in Africa is the need to (1) immediately undertake field surveys to determine the current distributions and abundance of these five subspecies of red colobus, and, at the same time, (2) rigorously protect all of those populations that are known to exist.

Providing adequate protection to viable populations of these five subspecies of red colobus would greatly assist the conservation of numerous sympatric threatened taxa. Among primates, these include: the mainland Preuss's monkey Cercopithecus preussi preussi; Bioko Preuss's monkey C. p. insularis; Bioko red-eared monkey C. erythrotis erythrotis; golden-bellied crowned monkey C. pogonias pogonias; Roloway monkey $C$. diana roloway; Bioko greater white-nosed monkey C. nictitans martini; Bioko black colobus Colobus satanas satanas; white-naped mangabey Cercocebus atys lunulatus; mainland drill Mandrillus leucophaeus leucophaeus; Bioko drill M. l. poensis; western chimpanzee Pan troglodytes verus; and Nigeria chimpanzee $P$. $t$. vellerosus.

If a concerted effort is to be made to save all of the diversity present within the red colobus, then the major international conservation NGOs will need to focus their efforts on this taxonomic group and work closely with national conservation NGOs and national protected area authorities. For P. p. bouvieri and $P$. b. waldroni, however, it may already be too late.

Thomas M. Butynski, John F. Oates, W. Scott McGraw \& Thomas T. Struhsaker

\section{Tana River Red Colobus}

Procolobus rufomitratus Peters, 1879

Kenya

(2002, 2004, 2006)

The gallery forests of the lower Tana River, Kenya, are home to two Critically Endangered primates, the Tana River red colobus and the Tana River mangabey, Cercocebus galeritus Peters, 1879. Along with six other primates, they inhabit small patches of forest along a $60-\mathrm{km}$ stretch of river, from Nkanjonja to Mitapani $\left(01^{\circ} 55^{\prime} \mathrm{S}, 40^{\circ} 05^{\prime} \mathrm{E}\right)$. While the other species of monkeys have larger geographic distributions, the red colobus and mangabey are restricted to these forests.

The two species receive some protection in approximately $13 \mathrm{~km}^{2}$ of forest within the $169-\mathrm{km}^{2}$ Tana River Primate National Reserve (TRPNR). Forest loss to agriculture, however, has increased greatly over the last 15 years or so, and it is estimated that about $50 \%$ of the original vegetation has been lost. In addition, local people continue to depend on the remaining forest for materials to build homes and canoes, for the collection of wild honey and other non-timber products. Further losses of habitat have occurred due to the failure of the Tana Delta Irrigation Project's (TDIP) rice-growing scheme (under the administration of the Tana and Athi Rivers Development Authority and financing from Japan International Cooperation Agency) to protect forest patches on their land. A consequence of this continuing loss and degradation of forest is that the populations of the red colobus and the mangabey are believed to have each declined to fewer than 1,000 individuals. Ominously, new threats are now on the horizon with a proposal to establish a large sugar cane plantation in the TDIP area. This new plantation is likely to result in a large influx of people and an increase in the demand for forest resources.

A 5-year World Bank/GEF project begun in 1996 to enhance conservation and protection of the primates and forests was terminated prematurely due to poor project management. This left responsibility for the conservation and protection of the Tana River's remaining forests and primates entirely to the Kenya Wildlife Service (KWS). Nevertheless, there are some positive developments. In 2005, more than 250 families who farmed within the TRPNR were voluntarily relocated to Kipini (about $90 \mathrm{~km}$ away) by the KWS. In addition, there appears to be an increasing concern for forest and biodiversity conservation among the people of the area and a major focus of action among community-based organizations is likely to be reforestation and ecotourism activities over the next few decades. However, given the current level of threat for these primates, it will take many years before there is sufficient change on the ground to reverse the long-standing decline of the populations of the Tana River red colobus and the Tana River mangabey.

David N. M. Mbora \& Thomas M. Butynski 


\section{Miss Waldron's Red Colobus}

Procolobus badius waldroni (Hayman, 1936)

Ghana and Côte d'Ivoire

(2000, 2002, 2006)

Miss Waldron's red colobus, P. badius waldroni, of western Ghana and eastern Côte d'Ivoire is teetering on the very brink of extinction (Struhsaker 1999; Oates et al. 2000; Groves 2001; Grubb et al. 2003). Primatologists have searched its known range since 1993, but have failed to see a living animal (Oates et al. 1996/1997; McGraw 1998, 2005; McGraw and Oates 2002). A single skin found in the possession of a hunter near the Ehy Lagoon in southeastern Côte d'Ivoire in early 2002 raised hopes that at least one population of Miss Waldron's red colobus still hangs on, but subsequent fieldwork in this region, including several forest reserves and nearby Isles Ehotiles National Park, has yielded no evidence of living individuals (Kone 2004; Kone and Akpatou 2005; McGraw 2005; Kone et al. 2007).

Through a partnership of Conservation des Espèces et des Populations Animales (CEPA) and the Centre Suisse de Recherches Scientifiques en Côte d'Ivoire (CSRS), Kone et al. (2007) surveyed 14 forest reserves in Côte d'Ivoire between 2004 and 2006, including Isles Ehotiles National Park. These surveys failed to provide any sightings of Miss Waldron's red colobus, only a claim of a single vocalization in Ehotiles in 2006. The forest adjacent to the Ehy Lagoon has not been surveyed since 2002, when no red colobus were found. However, the Ehy forest seems to be the only place in Côte d'Ivoire where a small population of Miss Waldron's red colobus might hang on. The forest is under heavy poaching pressure from Ivorian and Ghanaian hunters, and it is being logged, but Kone et al. (2007) have begun an awareness and education campaign in the villages there. Their plans are to build a community-based conservation system centered on the eight villages surrounding the lagoon. A thorough survey of the forest is needed as a matter of urgency.

In Ghana, very recent surveys (Oates 2006) support earlier suspicions that this monkey is almost certainly extinct in that country (Oates et al. 1996/1997; Struhsaker and Oates 1995). If any animals have managed to survive, the numbers must be very small and it will take heroic efforts to preserve them. Many forms of red colobus are endangered, including three other forms in West Africa: Pennant's red colobus (Procolobus pennantii pennantii) of Bioko Island (see profile in this report), Preuss's red colobus (P. p. preussi) of Cameroon, and the Niger River Delta red colobus (P. p. epieni). In addition, Bouvier's red colobus (P. p. bouvieri) from the Congo Republic has not been seen by scientists for at least 30 years. The plight of these monkeys highlights threats faced by red colobus generally; they have patchy distributions, have suffered extensive habitat degradation and are particularly vulnerable to hunters (Wolfheim 1983; Oates 1996; Grubb and Powell 1999; Oates et al. 2000; Struhsaker 2005). Implementation of a red colobus action plan should be a high conservation priority in Africa.

W. Scott McGraw \& John F. Oates
Kipunji (formerly the highland mangabey)

Rungwecebus kipunji (Ehardt, Butynski, Jones \& Davenport in Jones et al. 2005)

(formerly Lophocebus kipunji Ehardt, Butynski, Jones \& Davenport in Jones et al. 2005)

Tanzania

(2006)

The discovery of this new species of monkey in 2003 was the first in Africa in 20 years (Jones et al. 2005). First classified as Lophocebus kipunji, the highland mangabey, it has since been placed in a new genus Rungwecebus Davenport et al., 2006, on the basis of molecular data from an immature male specimen found in a trap in a farmer's field near Mt. Rungwe, Tanzania. While concerns have been expressed with respect to the designation of this new genus (Ehardt and Butynski 2006b), there is growing molecular (Olson et al. submitted) and also morphological evidence that Rungwecebus is valid. Taxonomic debates aside, this monkey is, without doubt, one of the world's most threatened primates (Davenport 2005; Davenport et al. 2006, submitted; Ehardt and Butynski 2006b). It has been assessed as Critically Endangered, following the IUCN Red List categories and criteria (Ehardt and Butynski 2006b; Hoffmann 2006).

The kipunji is believed to be endemic to two areas in Tanzania that are separated by $c .350 \mathrm{~km}$. The Ndundulu population lives at $1,300-1,750 \mathrm{~m}$ asl in an area of $<700$ ha of submontane forest in the Ndundulu Forest Reserve (about 18,000 ha of closed forest) in the Udzungwa Mountains of south-central Tanzania. Only three groups have been confirmed in this population, which is probably no more than 200 individuals in all (C. L. Ehardt unpublished; Ehardt and Butynski 2006b). The Mt. Rungwe-Livingstone population occupies $<7,000$ ha of degraded submontane and montane forest at 1,750-2,450 $\mathrm{m}$ asl in the Mt. Rungwe-Livingstone Mountains (about $562 \mathrm{~km}^{2}$, including the Kitulo National Park) of Tanzania's Southern Highlands (Davenport et al. 2006; Davenport et al. submitted). The Rungwe-Livingstone population has received more research attention than the Ndundulu population (Davenport 2005; Davenport et al. 2006, submitted, in prep.; De Luca et al. submitted), although a complete census of both populations has been completed recently (Davenport et al. submitted).

The most serious threat to the Mt. Rungwe-Livingstone population is the destruction of its forest habitat, a process which has proceeded unabated in this area for many years. The Livingstone Forest has been incorporated into Kitulo National Park, which should significantly improve protection for the kipunji groups in this area. Mt. Rungwe, however, remains a Catchment Forest Reserve and the level of protection there continues to be inadequate (Davenport 2006). There is already evidence that the Mt. Rungwe-Kitulo portion of the population consists of a number of isolated sub-populations (Davenport et al. submitted). The situation is compounded by the imminent loss of the narrow $(<2 \mathrm{~km}$ wide) Bujingijila Forest Corridor that joins Mt. Rungwe and Livingstone (Davenport 2005). With the loss of this corridor, the Mt. Rungwe- 
Livingstone population will be further fragmented. In addition to the continuing loss of habitat, this population continues to be hunted (Davenport 2005, 2006; Davenport et al. 2005, in prep.). Current rates of forest degradation and loss, especially through logging and charcoal production, could soon lead to the extirpation of the Mt. Rungwe-Livingstone population. What remains of the Mt. Rungwe-Livingstone forests requires immediate and sustained protection (Davenport and Jones 2005; Davenport 2006).

Of particular concern for the Ndundulu population is its extremely small size and the fact that poachers operate in this area (Ehardt and Butynski 2006b). Although local people have historically hunted in other parts of Ndundulu, there is no evidence that kipunji have been hunted here, and human disturbance in this part of the forest is minimal (Davenport and Jones 2005). The Ndundulu population is very small (Jones et al. 2005; Ehardt and Butynski 2006b; Davenport et al. submitted) however, and sizes of the groups thought to comprise this population appear to be smaller than those in the Mt. Rungwe-Livingstone population (Davenport et al. 2006, submitted; Ehardt and Butynski 2006b). These facts, alone, call into question the viability of this population of kipunji (Ehardt and Butynski 2006b; Davenport et al. submitted). Ndundulu Forest Reserve is currently subject to community-based management; however, with sanction from Tanzania's Ministry of Natural Resources and Tourism, Division of Forestry and Beekeeping, Tanzania National Parks is providing rangers to patrol the Ndundulu Forest Reserve, and a ranger post has been established at the edge of Ndundulu Forest.

Found in other forests of the Udzungwa Mountains is another of Tanzania's endemic monkeys, the Sanje mangabey Cercocebus sanjei Mittermeier, 1986, known to science only since 1979 (Homewood and Rodgers 1981). This mangabey is currently listed as Endangered (IUCN 2006), but was included in the 2004-2006 list of the World's 25 Most Endangered Primates (Ehardt and Butynski 2006a). Like the kipunji, it occurs in two populations (separated by $c .100 \mathrm{~km}$ ) and probably numbers fewer than 1,300 animals (Ehardt et al. 2005). The Mwanihana population occurs entirely within the Udzungwa Mountains National Park, where there is adequate protection and management based on continuing ecological research (Ehardt et al. 2005; Ehardt and Butynski 2006a). The Udzungwa Scarp population is found within the Udzungwa Scarp Forest Reserve, and is under severe threat as a result of habitat degradation and hunting. Thus far, efforts to extend the Udzungwa Mountains National Park to include the Udzungwa Scarp Forest have been unsuccessful. As such, at least $40 \%$ of the world's population of the Sanje mangabey remains at substantial risk of decline and eventual extirpation.

These two of Tanzania's endemic species of monkey, both recently discovered, are threatened with extinction due to habitat loss and hunting. Without significant improvement in the protection of the Mt. Rungwe-Livingstone Forest, where roughly $85 \%$ of the kipunji monkeys are found, and of the Udzungwa Scarp Forest, where nearly half of the Sanje mangabeys live, these two flagship species will have been part of Africa's known primate diversity for only a brief period in history.

Carolyn L. Ehardt, Thomas M. Butynski \& Tim R. B. Davenport

\section{Cross River Gorilla}

Gorilla gorilla diehli Matschie, 1904

Nigeria and Cameroon

(2000, 2002, 2004, 2006)

The Cross River gorilla (Gorilla gorilla diehli) is the most western and northern form of gorilla, and is restricted to the forested hills and mountains of the Cameroon-Nigeria border region at the headwaters of the Cross River. It is separated by about $300 \mathrm{~km}$ from the nearest population of western lowland gorillas (Gorilla gorilla gorilla), and by around $200 \mathrm{~km}$ from the recently-discovered gorilla population in the Ebo Forest of Cameroon. The most recent surveys suggest that between 200 and 300 Cross River gorillas remain. Groups of the gorillas concentrate their activities in eleven localities across a $12,000 \mathrm{~km}^{2}$ range, but genetic research has found evidence that despite their scattered distribution these subpopulations continue to maintain contact through the occasional migration of individuals.

There are currently two protected areas within the Cross River gorillas' range in Nigeria: the Afi Mountain Wildlife Sanctuary and the Okwangwo Division of Cross River National Park. In Cameroon, the Kagwene Gorilla Sanctuary is in the process of gazettement, and planning has begun for the creation of a Takamanda National Park. Beyond those protected areas, about half of the remaining Cross River gorillas occur in community-managed forests and a forest reserve (Mone River in Cameroon). There are many human settlements around the forests where the gorillas occur, and some villages are even enclaved within Okwangwo and Takamanda. The encroachment of farms, dry-season fires set to clear forest or improve pasture, and development activities, such as roads, are continuing threats to the integrity of gorilla habitat. However, large tracts of lower elevation forest remain between the localities where the gorillas are presently concentrated and if these areas can be protected, the animals could expand their range and their population. Genetic evidence suggests that the population of Cross River gorillas was much larger in the past, and that a dramatic decline has occurred over the last 200 years, almost certainly due to the introduction of hunting with firearms. After several years of awareness-raising by conservationists and researchers, hunting of Cross River gorillas for bushmeat has been reduced to a low level but it is still a potential threat, as are wire-snare traps set for other animals.

A conservation action plan for Cross River gorillas has been prepared, based on the deliberations of a workshop held in Calabar, Nigeria, in April 2006, organized by the Wildlife Conservation Society and funded by WWF's African Great Ape Programme and the U.S. Fish and Wildlife Service's Great Ape Conservation Fund (Oates et al. 2007). Among some of the key recommendations made by this workshop are for education and awareness efforts to be expanded, a transboundary 
conservation committee to be created, and new surveys to be launched in areas that are predicted by remote-sensing image analysis to support gorillas. The workshop recommended completion of the process to create protected areas at Kagwene and Takamanda, as well as the establishment of conservation systems at Mbe (Nigeria) and at Mone River, Mbulu and Bechati-Fossimondi (Cameroon). All these areas require management plans to be developed and implemented.

About $250 \mathrm{~km}$ south from the Cross River population, a small isolated population of gorillas occurs in a small portion of the $1,500 \mathrm{~km}^{2}$ forest straddling the Ebo River in southwestern Cameroon, approximately $50 \mathrm{~km}$ north of the Sanaga River. Field research undertaken by the Zoological Society of San Diego suggests that five or fewer gorilla groups survive in Ebo, which is also inhabited by ten other diurnal primates, including highly threatened forms such as the drill (Mandrillus leucophaeus), Preuss's red colobus (Procolobus pennantii preussi), and the Gulf of Guinea chimpanzee (Pan troglodytes vellerosus). The taxonomic affinities of the Ebo gorillas are still unclear. Based on measurements of a single skull, they may be most closely related to the gorillas of the inland plateau of Cameroon (south of the Sanaga River), rather than to Cross River gorillas. The Ebo gorilla population only became known to the outside world in 2001; they have been afforded little protection in the past, and the forest's primates are under extreme pressure from bushmeat hunting, given the proximity of the forest to the main urban centers in Cameroon. The Zoological Society of San Diego established a research station there in 2005, and with the full-time presence of researchers, along with technical assistance from WWF's Cameroon Coastal Forests Program, the conservation status of the Ebo Forest has improved and the area is currently being gazetted as a national park.

\section{Jacqui Sunderland-Groves, John F. Oates \& Bethan Morgan}

\section{Asia}

\section{Siau Island Tarsier}

Tarsius sp. Shekelle et al., in prep.

Indonesia

(2006)

The Siau Island tarsier is a new, undescribed species that is Critically Endangered (A1 acd) and faces an imminent threat of extinction. Shekelle and Salim (in press) used GIS data and field surveys to list specific threats. They include: a very small geographic range, of $125 \mathrm{~km}^{2}$, and an even smaller area of occupancy, perhaps as little as $19.4 \mathrm{~km}^{2}$; a high density of humans (311 people per $\mathrm{km}^{2}$ ) that habitually hunt and eat tarsiers for snack food; and an extent of occurrence that is entirely volcanic in its geological composition, with Mount Karengetang, a massive and highly active volcano, dominating more than $50 \%$ of the geographic range of this species. Furthermore, there are no protected areas within its range (Riley 2002; Shekelle and Salim in press; Shekelle et al. 2007), and all captive breeding programs for tarsiers, including several by leading zoos and primate centers, have been dismal failures, leaving no ex situ conservation options for any tarsier species anywhere (Fitch-Snyder 2003). The most reasonable interpretation of the scant data is that population size is very small, in the low thousands at best, and declining (Shekelle and Salim in press). Despite the fact that Sangihe Island is renowned for its Critically Endangered avifauna (Whitten et al. 1987; Whitten 2006), Shekelle and Salim (in press) found that the conservation threat for the tarsier on Siau Island was greater, for every variable measured, than that faced by T. sangirensis on Sangihe Island, which nevertheless is Endangered (B1 2ab). Thus, in spite of the fact that this species has yet to be described and is almost unknown, sufficient available evidence indicates that it teeters on the brink of extinction on an island where the entire endemic fauna and flora are at risk (Shekelle et al. 2007).

In Meyer's (1897) description of T. sangirensis, from Sangihe Island, he included a single skull from Siau Island (in the Dresden Museum, B321, from "Siao"). Sangihe and Siau Islands are part of a volcanic arc and are separated by approximately $60 \mathrm{~km}$ of deep ocean, greater than 1,000 $\mathrm{m}$ in depth. There is no feasible means for recurrent gene flow between these islands today, nor is there any historical indication of a land connection between these islands. Accordingly, Brandon-Jones et al. (2004) suggested that the Siau Island population is taxonomically distinct. Shekelle visited the island in March 2005 and found acoustic and morphologic evidence that supported taxonomic separation of the Siau Island population. Aside from the skull in Dresden, there is no evidence in the literature of research on this species. Shekelle's surveys found evidence of tarsiers in only two places, on the shores of a small fresh water pond at the extreme southern end of the island, and on a steep cliff face along the east coast road where it runs next to the ocean. Numerous other sites that looked promising, based upon experience with $T$. sangirensis, turned up no evidence of tarsiers. Interviews with several locals indicated that tarsiers had formerly been common at these sites as recently as 10 years ago, but were now rare or non-existent. They also added that tarsiers were a popular snack food called "tola-tola", and that it had formerly been common to eat 5 to 10 at a single sitting after hunting them with air rifles. It is unsurprising that tarsiers are no longer found in these areas.

Myron Shekelle \& Agus Salim

\section{Horton Plains Slender Loris, Ceylon Mountain Slender Loris}

Loris tardigradus nycticeboides Hill, 1942

Sri Lanka

(2004, 2006)

Slender lorises are small, nocturnal primates occurring in southern India and Sri Lanka. The two recognized species, comprised of six subspecies, are readily distinguished from all other primate taxa by large, close-set eyes, pencil-thin limbs, and a long body with only a hint of a tail. Unable to leap, these ninjas of the night move with a fluid and noiseless locomotion. Though they may be slow when startled, all of the slender 
lorises studied so far can move several kilometers per night, and have home ranges of 1.5 to $10 \mathrm{ha}$ - not small, considering that the various subspecies range in size from $110-350 \mathrm{~g}$.

The smaller of the two species, Loris tardigradus (Linnaeus, 1758), is found only in Sri Lanka's diminishing rainforests. In the 1960s, W. C. Osman Hill used the loris as the symbol of the Wildlife and Nature Protection Society of Sri Lanka, stating that it, being the most mysterious and rarely seen creature of Sri Lanka's jungles, was the most apt symbol for a society dedicated to revealing the unknown in nature. Two subspecies of this taxon, $L$. $t$. tardigradus and $L$. $t$. nycticeboides, are little better known today. The first long-term study of the red slender loris, L. t. tardigradus, was recently completed by Lilia Bernede of Oxford Brookes University, Oxford, UK. Continuing surveys of this subspecies by Nekaris and field assistants from the University of Ruhuna reveal that it is highly threatened, clinging to Sri Lanka's small remaining rain forest patches, which average only 1,300 ha in size.

The situation for the latter subspecies, L. t. nycticeboides, is no brighter. This rare little loris is found only in Sri Lanka's chilly highlands (where temperatures may drop to $-4^{\circ} \mathrm{C}$ ). To cope with these extremes, the Horton Plains slender loris has evolved a thick, woolly coat, which swathes its limbs, giving it the superficial appearance of its Southeast Asian counterpart, the greater slow loris, Nycticebus coucang. Even in 1942, Osman Hill wrote "That the animal is rare in the Horton Plains is evidenced by the fact that Mr. Tunein-Nolthenius has been on the look out for it for the previous twenty years without success." In 1980, this statement was further qualified by W. W. Phillips who stated that it "would appear to be the rarest of all mammals in Sri Lanka." This mysterious loris first appeared on this list of the World's 25 Most Endangered Primates in 2004, after Nekaris and Perera had carried out surveys for it at its type locality, the Horton Plains. They found only two animals after $60 \mathrm{~km}$ of surveys. This yielded an abundance estimate of $0.08-0.16$ animals $/ \mathrm{km}$. A return visit in 2004 by Nekaris and colleagues from the Wildlife Heritage Trust yielded only one observation, giving an abundance estimate of $0.02 \mathrm{animals} / \mathrm{km}$. These exceedingly low density estimates spurred Saman Gamage of the University of Ruhuna to lead a team in search of this most elusive of the lorises. Interestingly, after 21 nights of targeted efforts, abundance estimates generated in 2006 were the same: 0.02 animals $/ \mathrm{km}$.

On the brighter side, Gamage's team have found this loris in two new localities, Haggala Strict Natural Reserve, and Bomburella forest. An unusual museum specimen uncovered in the Natural History Museum of Colombo examined by Colin Groves also suggests that the range of this species may extend as far as Sri Lanka's Knuckles Range, expanding its known area of extent from $30 \mathrm{~km}^{2}$ to $250 \mathrm{~km}^{2}$. A search to identify the lorises in this region will be instigated in 2007 by Sandun Perera of Sabaragamuwa University of Sri Lanka.

Although still imperilled by continued habitat loss, gem mining, agricultural encroachment, as well as being hunted and captured for medicines, as pets, and uses resulting from local folklore, there is a glimmer of hope for this small nocturnal primate. Virtually ignored since its discovery in the 1940s, media exposure from this list has now spurred two studies of this primate by local researchers. It is our hope that in 2008, more populations will be discovered, and that the Horton Plains slender loris can sink back into that dubious comfort of being 'only Endangered.'

K. Anna I. Nekaris

\section{Simakobu or Pig-Tailed Snub-Nose Langur}

Simias concolor Miller, 1903

Indonesia (Mentawai Islands)

(2002, 2004, 2006)

The simakobu monkey is serving as the flagship species for a group of endangered primates endemic to the remnants of forest on the $7,000-\mathrm{km}^{2}$ Mentawai Islands. The four main islands are located $85-135 \mathrm{~km}$ off of the west coast of Sumatra and are home to three other primate species - Kloss's gibbon (Hylobates klossii), the Mentawai pig-tailed macaque (Macaca pagensis), and the Mentawai Island leaf langur (Presbytis potenziani). Simias concolor concolor Miller, 1903 inhabits the islands of Sipora, North Pagai, and South Pagai along with several small islets off southern South Pagai. Simias c. siberu Chasen and Kloss, 1927 occurs only on Siberut Island. Where Simias still occurs on the Pagai Islands, it exists at lower densities than on Siberut.

Although the first simakobu specimens were collected in 1902, researchers did not begin studying the Mentawai primates until the 1970s. In 1996, two simakobu groups were habituated to the presence of humans and studied in Betumonga, in the southwestern region of North Pagai Island. Researchers with the Siberut Conservation Project in the Peleonan Forest in northern Siberut are in the process of habituating more simakobu and other primate groups. Simakobus are arboreal quadrupeds that eat leaves, fruits, and flowers, and exhibit a variable social organization.

All four of the Mentawai primates are affected by habitat disturbance and hunting (Whittaker 2006). Although hunting appears to be declining and opportunistic, human encroachment and timber removal are increasing. Of the four Mentawai primates, simakobus seem to be the most sensitive to logging. On the Pagais, density estimates range from a high of 5.17 simakobus per $\mathrm{km}^{2}$ in unlogged forests to a significantly lower density of $2.54 \mathrm{ind} / \mathrm{km}^{2}$ in forests that were logged in the 1980s (Paciulli 2004). Twenty-five years ago, simakobus were found in areas of mixed primary and secondary forests on Siberut at densities as high as $220 \mathrm{ind} / \mathrm{km}^{2}$ (Watanabe 1981). In 1990, however, no evidence could be found of Simias inhabiting several areas on Siberut and the Pagais (Tenaza and Fuentes 1995).

Today, the Mentawai primates continue to exist in some residual forest patches on the Pagais and Sipora, and parts of the 190,500-ha (470,735 acres) Siberut National Park (also a UNESCO Biosphere Reserve) that covers $47 \%$ of the island. Thus, while Simias and the other Mentawai primates still survive in spite of human encroachment, hunting, and timber removal, the vast majority of the remaining natural habitat 
lies outside of officially protected areas. Most of these areas are in logging concessions and could very well be lost in the near future as there is talk of clear cutting in 2008 for oil palm plantations.

Lisa M. Paciulli

\section{Delacour's Langur}

Trachypithecus delacouri (Osgood, 1932)

Vietnam

(2000, 2002, 2004, 2006)

Delacour's langur is endemic to Vietnam and occurs in a very restricted area of northern Vietnam which comprises about $5,000 \mathrm{~km}^{2}$ between $20^{\circ}-21^{\circ} \mathrm{N}$ and $105^{\circ}-106^{\circ} \mathrm{E}$. The distribution is closely linked to the limestone mountain ranges in the provinces of Ninh Binh, Thanh Hoa, Hoa Binh and Ha Nam. Currently there are 19 locations where Delacour's langur is or was known to occur. They are isolated populations and when combined total at most only 400 to $450 \mathrm{~km}^{2}$. The extirpation of Delacour's langurs has been reported by local people in three localities that we know of. There is a smaller limestone mountain ridge to the west extending to a large limestone region north of Son $\mathrm{La}$, but there is no evidence of Delacour's langurs in this area. The northwestern border of the distribution is Mai Chau between the Da River in the north and the Ma River in the south. The Da River appears to form the northern border of the species' range. The exact southern boundary is unclear. There are some smaller isolated limestone areas south of the Ma River. The only area south of the Ma River where Delacour's langurs have been confirmed is the limestone complex between Lang Chan and Ngoc Lan, but this population is now most probably extirpated. It seems that this species never occurred south of the Chu River.

During the decades following the discovery of Delacour's langur in 1930 there was only scanty information on its existence and distribution. The first sightings of live animals were reported in 1987 from Cuc Phuong National Park. The most important, and for some subpopulations the only factor for the decline in numbers is poaching, which is not primarily for meat, but for bones, organs and tissues that are used in the preparation of traditional medicines. The 19 isolated wild populations of Delacour's langur have been confirmed over 10 years of surveys and monitoring by the Frankfurt Zoological Society. The total population counted in 1999/2000 was about 280 to 320 individuals. The recorded numbers of animals hunted over the 10 years totaled 320 , an annual loss of more than 30 individuals, but the real number is undoubtedly higher. Sixty percent of all existing Delacour's langurs occur in isolated populations with less than twenty animals. The loss of these subpopulations, and consequently sixty percent of the entire population, is foreseeable without management, strict regulations and law enforcement. Surveys in 2004 in two protected areas with important subpopulations, Cuc Phuong National Park and Pu Luong Nature Reserve, showed a decline in numbers of $20 \%$ in the last 5 years. It is to be expected that the population in unprotected areas which have yet to be surveyed will show a similar tendency. A reasonable estimate of the current population indicates numbers no higher than 200 to 250 individuals.

Four areas where Delacour's langurs occur are protected: Cuc Phuong National Park, Pu Luong Nature Reserve, Hoa $\mathrm{Lu}$ Cultural and Historical Site, and the Van Long Nature Reserve (established in 2001). Van Long Nature Reserve is believed to harbor the largest remaining population of about 60 to 80 animals. They are well protected there due to patrols and close cooperation between the provincial forest protection authorities and Frankfurt Zoological Society. Currently two doctoral students are working in the area, studying the biology and population dynamics of the subpopulation. Efforts to save this species are being led by Tilo Nadler, manager of the Vietnam Primate Conservation Program of Frankfurt Zoological Society and director of the Endangered Primate Rescue Center at Cuc Phuong National Park, established in 1993 primarily to safeguard the future of this and other endangered Vietnamese primates. The Endangered Primate Rescue Center is the only facility which keeps this species. The center started a breeding program with five confiscated animals, and 12 individuals have been born since 1996. The aim is to reintroduce the langurs into well-protected areas to establish additional free ranging populations.

Tilo Nadler \& William R. Konstant

\section{Golden-headed Langur or Cat Ba Langur}

Trachypithecus poliocephalus poliocephalus (Trouessart, 1911)

Vietnam

(2000, 2002, 2004, 2006)

The golden-headed langur, Trachypithecus p. poliocephalus, is probably the most endangered of the Asian colobines. This species only occurs on the Island of Cat Ba in the Gulf of Tonkin, northeastern Vietnam. The Cat Ba Archipelago is in the world-famous Ha Long Bay, a spectacular karst formation that was invaded by the sea. The golden-headed langur inhabits tropical moist forest on limestone karst hills, and shares this habitat preference with the six to seven taxa of the T. francoisi group. Among these so called karst langurs, the Cat Ba langur and its closest relatives, the white-headed langur, T. $p$. leucocephalus Tan, 1955, in southern China, and the wideranging Francois' langur, T. francoisi (Pousargues, 1898), the northernmost representative of the genus, display the strictest behavioral adaptations to their karst habitat.

There are no systematic and reliable data available on the historic density of the langur population on Cat Ba Island. According to reports of indigenous people the entire island of Cat $\mathrm{Ba}\left(140 \mathrm{~km}^{2}\right)$ and some smaller offshore islands were previously densely populated by langurs. Hunting has been the sole cause for the dramatic and rapid population decline from an estimated 2,400-2,700 in the 1960s to only 53 individuals by 2000 . The langurs were poached mainly for trade in traditional medicines. Since the implementation of strict protection measures towards the end of 2000, the langur population on $\mathrm{Cat} \mathrm{Ba}$ Island increased to a current 65 individuals $(+22.5 \%)$. 
Although the growth of the population is encouraging, the overall status of the species is most critical. As a result of habitat fragmentation, the remaining population is now divided into seven isolated sub-populations, five of which include or consist of all-female groups, thus non-reproducing social units. The estimated effective population size is 29 individuals at most. Only three groups are currently reproducing, and the total reproductive output in this species is accordingly low. Since a peak in births in 2003, the reproductive output of the $\mathrm{Cat} \mathrm{Ba}$ Langur has stagnated at 1-2 offspring per year.

$\mathrm{Cat} \mathrm{Ba}$ Island and the surrounding area are nationally and internationally recognized for their importance to biodiversity conservation. Cat Ba National Park was established in 1986. It presently covers more than half of the main island. The Cat Ba Archipelago (some 1,500-2,000 large and small islands, cliffs and rocks) was designated a UNESCO Man and Biosphere Reserve in 2004. Despite this, nature and wildlife protection on Cat Ba Island is deficient. Efforts to effectively conserve the langurs and their habitat face major obstacles because of the lack of partnership and commitment with the local communities and the need to better address their aspirations for development, and due to the steadily increasing human population, besides persistent, severe deficiencies in law enforcement. As elsewhere in the region, poaching is driven by increasingly attractive commercial gains in satisfying the immense local and regional demand for wildlife. The strictest protection regime possible is necessary for the survival of all the mammals and other species on Cat $\mathrm{Ba}$ that are, like the langurs, targeted by the Asian wildlife trade.

A conservation program for the golden-headed langur on Cat Ba was initiated in November 2000 by the Zoologische Gesellschaft für Arten- und Populationsschutz (ZGAP), München, in cooperation with Allwetterzoo, Münster, Germany. The aim is to provide for their protection, reduce population fragmentation, and contribute to the conservation of the biodiversity on Cat Ba Island in collaboration with Vietnamese authorities.

\section{Roswitha Stenke, Phan Duy Thuc \& Tilo Nadler}

\section{Western Purple-faced Langur}

Semnopithecus vetulus nestor Bennett, 1833

Sri Lanka

(2004, 2006)

Endemic to Sri Lanka, this langur is restricted to a small area of the wet zone in the west of the country, most of which is threatened due to human activities (crops, infrastructure and industry, settlements, deforestation and forest fragmentation, and hunting). Colombo, the capital city of Sri Lanka, is in the center of its very limited range. Hill (1934) indicated that it was common around the capital, but this is no longer the case. Forest cover in Sri Lanka has declined drastically since the late 1950s, and the area of occupancy of this langur has been reduced to a highly fragmented $1,900 \mathrm{~km}^{2}$ (Molur et al. 2003). Although still quite numerous $(>10,000)$, the declines in numbers are expected to have been precipitous - estimated at more $80 \%$ in three generations due to urbanization and development.
Western purple-faced langurs are highly arboreal and need good canopy cover, and there are possibly less than three forests that can support viable populations, none of which are protected areas set aside for conservation. The human-modified areas that sustain much of the langur population, such as gardens and rubber plantations, are under private ownership and changing rapidly due to human population expansion and development; large trees are cut down and entire forest patches are destroyed for housing and development. This severely restricts home ranges, isolating the groups, and resulting in escalated conflict with humans and low juvenile recruitment rates (Dela 1998). Long-term studies by Dela (1998) have shown that this taxon is unique in having subpopulations adapted to a diet high in mature/ripe fruit, a feature as yet unrecorded for any other colobine, and are dependent on fruits cultivated by humans.

The geographical range of the species has a very high human population density, and home ranges are being compressed due to loss of tree cover. Censuses are urgently needed to identify forest areas for conservation and to better quantify the decline of subpopulations in space and time, and to provide a better understanding of their demographics (especially reproductive rates, population turnover and dispersal) in the extremely disturbed habitats where they survive today.

Jinie Dela \& Noel Rowe

\section{Grey-shanked Douc}

Pygathrix cinerea Nadler, 1997

Vietnam

(2000, 2002, 2004, 2006)

The colobine monkeys of the genus Pygathrix are native to Indochina. Until only ten years ago, just two distinct taxa were recognized: the red-shanked douc, Pygathrix nemaeus, named by Linnaeus in 1771, in the northern part of Central Vietnam and Central Laos; and the black-shanked douc, P. nigripes, from South Vietnam and east Cambodia, described exactly a century later by Milne-Edwards. The grey-shanked douc was first described as a subspecies of the red-shanked douc, but genetic studies have since demonstrated a divergence at species level. It occurs in Central Vietnam between $13^{\circ} 30^{\prime}$ and $16^{\circ} \mathrm{N}$, and has been recorded in five provinces: Quang Nam, Quang Ngai, Kon Tum, Gia Lai and Binh Dinh. Currently grey-shanked doucs are known only from Vietnam, but records exist close to the border to Laos, and there are photos of hunted animals from southeast Laos and far northeast Cambodia that suggest that the species occurs in small neighboring areas in both countries. Surveys and research on this recently discovered primate have been conducted by the Frankfurt Zoological Society, led by Tilo Nadler, manager of the Vietnam Primate Conservation Program of Frankfurt Zoological Society and director of the Endangered Primate Rescue Center at Cuc Phuong National Park, and Ha Thang Long, biologist at the Rescue Center.

Grey-shanked douc populations are fragmented and estimated to total $600-700$ individuals. Their occurrence has 
been confirmed in eight protected areas: Song Thanh Nature Reserve, Ngoc Linh Nature Reserve, Ba To Cultural and Historical Site, An Toan Nature Reserve, Kon Cha Rang Nature Reserve, Kon Ka Kinh National Park, Mom Ray National Park and A Yun Pa Nature Reserve. However, hunting, the principal threat to the species, is still a problem inside these parks and reserves. Snares are the most commonly used method since gun confiscation programs were carried out in a number of the areas. Often hundreds of traps are installed in trees frequently used by the langur groups, as well as on the ground where they are seen crossing between small forest patches. Trapped animals are often severely injured and mutilated. Forest loss within at least part of the species' range is attributable to the expansion of agriculture, illegal logging and firewood collection. Almost 10,000 ha of forest are destroyed every year in the Central Highlands.

The Endangered Primate Rescue Center has received 37 confiscated grey-shanked douc langurs since 1995, and has begun a breeding program to provide stock for reintroduction in protected forests. Based on information from villagers and forest protection authorities, less than one-quarter of the hunted animals are confiscated alive. Ha Thang Long, the biologist of the Endangered Primate Rescue Center, is studying the species in Central Vietnam specifically to provide recommendations for the establishment of special "Species Protection Areas," which will promote connectivity between the currently isolated populations in the established parks and reserves.

\section{Ha Thang Long \& Tilo Nadler}

\section{Tonkin Snub-nosed Monkey}

Rhinopithecus avunculus Dollman, 1912

Vietnam

(2000, 2002, 2004, 2006)

The Tonkin snub-nosed monkey is one of four unusual, large Asian colobine monkeys of the genus Rhinopithecus, all of which possess a characteristic turned-up nose. The three other species are endemic to China, while the Tonkin snubnosed monkey is found only in northern Vietnam. This species was discovered in 1911, collected on perhaps no more than two occasions over the course of the next 50 to 60 years, and subsequently presumed to be extinct by a number of primatologists until it was rediscovered in 1989. Historically the species occurs only east of the Red River between about $21^{\circ} 09^{\prime}-23^{\circ} \mathrm{N}$. Due to massive deforestation and intensive hunting in recent decades, its distribution has become dramatically restricted.

Currently, there are only four known locations with recent evidence where Tonkin snub-nosed monkeys occur, and these are completely isolated. In 1992, a population was found in $\mathrm{Na}$ Hang District, Tuyen Quang Province. As a result of the discovery, a nature reserve was established in 1994. The nature reserve comprises two separate areas: the Ban Bung and Tat Ke sectors. A study in 1993 estimated a population of between 95 and 130 individuals in each sector, respectively, which was probably overestimated. A later study, in 2004-2005, found far lower densities, and estimated only 17-22 individuals in the Tat Ke sector. For the subpopulation of Na Hang Nature Reserve, the most serious threat was a hydropower and flood prevention dam project. Construction began in 2002. Some 10,000 workers moved into the area for dam construction, which has increased the demand for wildlife products and firewood. Conservation activities carried out by several organizations have been unsuccessful, and resulted in a reduction of this subpopulation.

A population of about 70 individuals was estimated for Cham Chu Nature Reserve, also in Tuyen Quang Province. Based on local interviews during a survey reported in 1992 the population was believed to have dropped to only $20-40$ individuals. A survey in 2006 provided no sightings and no reliable evidence of the survival of the population. Local reports indicate, however, a small group of 8-12 individuals still in the area. A population of about 60-90 Tonkin snub-nosed monkeys was discovered 2001 in Khau Ca, close to Du Gia Nature Reserve, Ha Giang Province. This is the only population which is not immediately threatened. There, public awareness and community participatory activities are being linked to increased protection efforts under the supervision of Fauna \& Flora International (FFI). The total population of the Tonkin snub-nosed monkey is believed to be less than 150 individuals.

\section{Le Khac Quyet, Tilo Nadler \& William R. Konstant}

\section{Hainan Gibbon}

Nomascus hainanus (Thomas, 1892)

China (Island of Hainan)

(2000, 2002, 2004, 2006)

The taxonomy of the crested black gibbons, genus Nomascus is still in debate, but experts now believe there are three species: the Hainan gibbon, Nomascus hainanus, the most endangered of any of the gibbons and restricted to the island of Hainan (Geissmann 2003; Geissmann and Chan 2004; Wu et al. 2004; Zhou et al. 2004); the eastern black gibbon, Nomascus nasutus, occurring in northeast Vietnam (Nadler 2003), and adjoining Guangxi Zhuang Autonomous Region, China (Chan et al. in prep.); and the western black gibbon, Nomascus concolor, occurring in central Yunnan, China, and Indochina. A recent study found no molecular differences between the putative subspecies of $N$. concolor, but significant genetic differences between the forms hainanus and nasutus (Roos et al. 2007). The Hainan gibbon and eastern black gibbon differ in their hair coloration (Geissmann et al. 2000; Mootnick 2006) and territorial calls (La Q. Trung and Trinh D. Hoang 2004). These characteristics, in association with the newly discovered genetic differences, suggest that the Hainan gibbon and eastern black gibbon be considered distinct species (Roos and Nadler 2005; Roos et al. 2007).

Adult male eastern black gibbons are black and can have a slight tinge of brown hair on the chest. Adult male Hainan gibbons are entirely black (Geissmann et al. 2000; Mootnick 2006). Adult female Hainan gibbons and eastern black gibbons vary from a buffish to a beige brown and 
have a black cap (Geissmann et al. 2000; Mootnick 2006). The adult female Hainan gibbon has a thin, white face ring that is thicker above the mouth and below the orbital ridge. The hair surrounding the face of the female Hainan gibbon creates a rounded appearance encircling the face. The hair grows outwards on the side of the face and in a more downward direction as it gets closer to the chin. This contrasts with the female northern white-cheeked gibbon (Nomascus l. leucogenys), whose facial appearance is slightly similar to the female Hainan gibbon. The hair on the outer sides of the face of the female white-cheeked gibbon grows in a more upward direction giving the face a more triangular appearance. Depending on the amount of humidity, female Nomascus can acquire a more orangey color resulting from their sweat (Mootnick 2006). The only account of a live female eastern black gibbon in close proximity was of a female "Patzi" in the Berlin Zoo whose vocalizations were similar to that of the eastern black gibbon, but her pelage differed in that she had a very long and broad black crown streak that went past the nape, and extended to the brow, tapering to a thin face ring and becoming thicker at the chin (Geissmann et al. 2000; Mootnick 2006). This female had a narrow blackish-brown chest plate slightly wider than the face, beginning at the throat and tapering at the top of the abdomen. At this time Patzi had more black than what has been observed in the wild or in museum specimens of female eastern black gibbons.

The eastern black gibbon was thought to be extinct in southwestern provinces of China in the 1950s. In the 1960s, it was also feared extinct in Vietnam, but was rediscovered after intensive searches in January 2002 by Fauna and Flora International (FFI) biologists La Q. Trung and Trinh D. Hoang (2004). They found five groups totaling 26 individuals in the remaining 3,000 ha of limestone forest of Phong Nam-Ngoc Khe Mountains, Trung Khanh District, northern Cao Bang Province bordering Guangxi in China. Further surveys by the Vietnam Primate Conservation Programme of FFI and Trung Khanh District rangers in November 2004 located 37 individuals (VNA 2004). Recently, a team of researchers from Kadoorie Farm \& Botanic Garden (KFBG) and China confirmed 17 eastern black gibbons in three groups in the Bangliang limestone forest of Jingxi County in Guangxi, neighboring the Phong Nam-Ngoc Khe Mountains of Vietnam. Some of the gibbons observed in Bangliang may be the same individuals counted by Vietnamese counterparts as gibbon groups were seen traveling between the two countries (People's Daily Online 2006; Chan et al. in prep.). There is rumor that there might be some eastern black gibbons in Kim Hy Nature Reserve, Bac Kan Province, Vietnam, as well as other border areas in Guangxi, China.

In the 1950s there were estimates of $>2,000$ Hainan gibbons on the island of Hainan in 866,000 ha of forests across 12 counties (Wang and Quan 1986). By 1989, the Hainan gibbon population was reduced to only 21 gibbons in four groups restricted to Bawangling Nature Reserve (Liu et al. 1989). In 1998 the population was said to be 17 (Kadoorie Farm
\& Botanic Garden 2001). A gibbon survey in October 2003 found two groups, and two lone males, comprising a total of 13 individuals (Fellowes and Chan 2004; Geissmann and Chan 2004; Chan et al. 2005; Zhou et al. 2005); another survey in 2001-2002 estimated 12-19 individuals in four groups (Wu et al. 2004). In recent months three newborns and at least one lone female have been observed, bringing the world total to 17 individuals (Hainan Daily Online 2007a).

Gibbons generally establish long-term pair bonds, but in Bawangling National Nature Reserve (BNNR) there have been repeated observations of two females in the same group both carrying offspring (Liu et al. 1989; Bleisch and Chen 1991; Hainan Daily Online 2007a). This "non-traditional" group could be the result of older offspring being unable to locate appropriate mates (Wu et al. 2004), limited space to establish new groups (Liu et al. 1989), or could reflect habitual bigyny as in the crested black gibbons of Yunnan (Bleisch and Chen 1991; Fan et al. 2006). If fresh feces could be collected from these individuals, it is possible that nuclear DNA sequencing could determine the relationships and confirm if observations are being conducted on the same group in different locations.

Since 2003, when the first Hainan Gibbon Action Plan was launched (Chan et al. 2005), several teams have continued to work roughly in line with the Plan, though with limited coordination. Conservation actions include surveying the distribution of the Hainan gibbon, providing training of staff to monitor the gibbons, restoring the forest, and community conservation work. One team consists of the KFBG, the Hainan Wildlife Conservation Centre of the Hainan Provincial Forestry Department (HWCC), and BNNR. The second (FrancoChinese) team consists of East China Normal University of Shanghai (ECNU), the Zoological Society of Paris (PZS), and BNNR. A third team from Fauna and Flora International (FFI) China has also conducted monitoring, training and community work in the recent past.

With only 17 Hainan gibbons and 54 eastern black gibbons confirmed, each surviving in just one small forest block, the Hainan gibbon and eastern black gibbon are among the most critically endangered primates in the world. It is important to gain full support from the surrounding community for conservation of the gibbons and their habitat, possibly by ensuring benefits linked to their compliance with conservation goals, and ensuring longer-term commitment from the government and outside partners. Efforts are underway to contribute to the conservation of the eastern black gibbon in Vietnam with the establishment of community-based protection activities. Since there are unconfirmed reports of gibbon occurrences from other forests, additional surveys need to be conducted in both Guangxi and Hainan (Hainan Daily Online 2007b). There is an urgent need to secure and expand suitable forest for the survival of the few remaining gibbons and their habitats, which will require continued effort and cooperation among all parties.

Alan R. Mootnick, Xiaoming Wang, Pierre Moisson, Bosco P. L. Chan, John R. Fellowes \& Tilo Nadler 


\section{Western Hoolock Gibbon}

Hoolock hoolock (Harlan, 1831)

Bangladesh, India, Myanmar

(2006)

The hoolock gibbon was formerly in the genus Bunopithecus with just one species and two subspecies: $B$. hoolock hoolock, the western hoolock gibbon, and $B$. hoolock leuconedys Groves, 1967, the eastern hoolock gibbon from Myanmar and China. Mootnick and Groves (2005) informed that the name Bunopithecus was not valid, and placed it in a new genus, Hoolock, and at the same time argued that the two forms were distinct species (but see Mootnick 2006). The western hoolock gibbon (Hoolock hoolock) occurs in Bangladesh, northeastern India and western Myanmar, west of the Chindwin River. Its range in Myanmar, known from just a few field studies and mostly informal sightings, is restricted to the western parts, delineated from the populations of Hoolock leuconedys by the Chindwin River as far as the head waters in the north. In India and Bangladesh its range is strongly associated with the occurrence of contiguous canopy, broad-leaved, wet evergreen and semi-evergreen forests. The species is an important seed disperser; its diet includes mostly ripe fruits, with some flowers, leaves and shoots.

Western hoolock gibbons face numerous threats in the wild, and are now entirely dependent on human action for their survival. The debilitating threats include habitat encroachment to accommodate ever-growing human populations and immigration, forest clearance for tea cultivation, the practice of jhuming (slash-and-burn cultivation), hunting for food and "medicine", capture for trade, and the degradation and decline in quality of their forests that impacts fruiting trees, canopy cover and the viability of their home ranges. Isolated populations face the additional threats arising from the intrinsic effects of small populations. Some populations surviving in just a few remaining trees are subjected to harassment by locals and to lack of food, and are attacked by dogs while attempting to cross clearings between forest patches.

Based on habitat loss over the last 30-40 years, western hoolock gibbons are estimated to have declined from more than 100,000 (Assam state alone was estimated to have around 80,000 in the early 1970 s) to less than 5,000 individuals (a decline of more than 90\%). The species was known to occur in good numbers in contiguous forests, which have borne the brunt of persistent human impacts. Isolated forest fragments hold just some few families - numbers insufficient for survival in the mid- to long-term. Apart from some border forests between India and Myanmar, the remaining habitat is fragmented, holding minimal populations of this sort. We have documented the extirpation of western hoolock gibbons from 18 locations over the last 3-5 years; eight in Bangladesh and 10 in India. Bangladesh has about 200 western hoolock gibbons in 22 separate locations, twenty of which have less than 20 individuals each: 17 of these have less than 15 individuals, and 14 have less than 10 individuals. About 100 locations with hoolock gibbons have been recorded in India; 77 have less than 20 individuals, and 47 of these have less than
10 individuals. The Population Viability Analysis (PVA) predicts a $95 \%$ decline in the population in Bangladesh and a $75 \%$ decline in the population in India over the next two decades based on the current effects of human impacts and the intrinsic factors acting on very small and isolated populations.

The population of the western hoolock gibbon in Myanmar has not been surveyed. West of the Ayeyarwaddy-Chindwin River, there is about $50,000 \mathrm{~km}^{2}$ of forest in the Rakhine Yoma region, but much of it is degraded and hunted. The area includes the Rakhine Yoma Elephant Range (about 175,500 ha), managed by the Nature and Wildlife Conservation Division of the Forest Department of Myanmar, in Rakhine State, in the lower part of the country (about $17^{\circ} \mathrm{N}$ ). There are other forested areas farther to the north, including the Chin Hills Complex and the Naga Hills area, but they are considered unsafe for travelers. No published information is available on the current range and status of the western hoolock in Myanmar. Warren Brockelman has been carrying out surveys of the eastern hoolock, Hoolock leuconedys Groves, 1967, in accessible protected areas east of the Chindwin River in Myanmar since 2005, and preliminary results indicate that the situation there is considerably more encouraging, with relatively large populations still surviving. The population trends for the western hoolock observed over recent years in Bangladesh and northeast India indicate a very rapid decline in numbers and immediate measures are required by their governments, forest departments, local communities and NGOs.

Sally Walker, Sanjay Molur \& Warren Y. Brockelman

\section{Sumatran Orangutan}

Pongo abelii Lesson, 1827

Indonesia (Sumatra)

(2000, 2002, 2004, 2006)

Sumatran and Bornean (Pongo pygmaeus Linnaeus, 1760 ) orangutans, now recognized as two distinct species, comprise the genus Pongo. While there are considered to be three subspecies of $P$. pygmaeus, the Sumatran orangutan is regarded as a single taxonomic unit. The viability of all taxa is in question, but the Sumatran orangutan faces a more immediate extinction risk than the Bornean, and is considered Critically Endangered.

The species is endemic to Sumatra, Indonesia, and is now entirely restricted to remaining lowland forests in Nanggroe Aceh Darussalam (NAD) and North Sumatra Provinces. About 7,000 individuals remain (based largely on 2002 satellite imagery), surviving in 13 fragmented habitat units stretching from northern NAD, south to the Batang Toru River in North Sumatra, with a notable gap in their distribution immediately west of Lake Toba. The southernmost populations may be genetically and culturally distinct from their more northern relatives. The largest populations live within NAD province, where until recently, a separatist conflict made monitoring and conservation work problematic.

By far the most significant populations, totaling about 5,600 animals, are found within the Leuser Ecosystem, a $26,000 \mathrm{~km}^{2}$ conservation area established by presidential 
decree that encompasses the smaller Gunung Leuser National Park (10,950 km²; itself part of the Sumatran Rainforest World Heritage Site) and the $1,025 \mathrm{~km}^{2}$ Singkil Swamps Wildlife Reserve within its boundaries. The Ecosystem and the national park within it form the only conservation area of note where viable wild populations of the Sumatran orangutan, Sumatran tiger, Sumatran rhinoceros and Sumatran elephant, each of which is endangered in itself, still occur living side by side. The National Park, however, is predominantly high mountains, and as the orangutan is a predominantly lowland creature, rarely being found above $1,000 \mathrm{~m}$ asl, the majority occur within the larger Ecosystem but outside the National Park. For example, the Ecosystem harbors $c .75 \%$ of the remaining 7,000 Sumatran orangutans whilst only $24 \%$ are found within the National Park and 20\% within the Singkil Swamps Wildlife Reserve.

Throughout its range, the primary threat to Sumatran orangutans is logging, both legal and illegal, which often leads to total conversion of forests for agriculture or oil palm plantations. Although exact figures are still unavailable, primary lowland forests in Sumatra have been devastated over the last 20 years. One analysis of satellite imagery concluded that habitat supporting around 1,000 orangutans was being lost each year in the Leuser Ecosystem alone during the late 90's (van Schaik et al. 2001). This was largely due to legal logging concessions and conversion of lowland forests to palm oil estates, but also illegal logging and encroachment in some places. Fortunately, however, the rate of habitat loss decreased markedly in many areas during the Aceh civil conflict, as activities in the forests became unsafe, and as a result of a moratorium imposed on logging in the province by the Aceh government. Orangutan populations have nevertheless plummeted in regions that have been affected by logging. Even small scale illegal logging can reduce local orangutan densities by as much as $60 \%$ in Sumatra (Rao and van Schaik 1997). At least six of the remaining seven populations containing over 250 individuals have experienced between 10 and $15 \%$ annual habitat loss due to logging. Encroachment and conversion, especially by settlers fleeing the conflict in NAD and migrants from Nias Island, have accelerated habitat loss in some parts. Relocation of people from coastal areas and an increase in demand for timber after the 2004 tsunami poses a significant new threat. Several proposed new roads (known as the Ladia Galaska project) will lead to a major increase in fragmentation of remaining orangutan populations. Throughout their range orangutans are sometimes killed as pests along forest edges as they raid agricultural crops, and in the far south of their range they are occasionally still hunted as food. A small but significant pet trade in young Sumatran orangutans also persists.

Key conservation interventions rely heavily on a dramatic and rapid improvement in enforcement of wildlife and forest laws and far greater consideration for environmental issues in spatial planning decisions. Implementing patrols, improving law enforcement, stopping illegal logging, halting legal logging and forest conversion to plantations, promoting forest restoration, halting road construction, addressing human-orangutan conflict, and providing connectivity in the landscape to allow for genetic exchange are all seen as pre-requisites for the species' survival. If current rates of habitat loss persist a further $50 \%$ of Sumatran orangutans will vanish within a decade. However, there is as much reason to believe the rate of decline will actually increase due to higher demand for timber, fragmentation by roads, expansion of plantations and general population pressure, as there is for mitigation of these threats. Solutions to conserve the remaining lowland primary forests are urgently needed.

Ian Singleton, Susie Ellis \& Mark Leighton

\section{Neotropical Region}

\section{Variegated or Brown Spider Monkey}

Ateles hybridus I. Geoffroy, 1829

Colombia, Venezuela

(2006)

There are two recognized subspecies of the variegated or brown spider monkey. Ateles hybridus brunneus Gray, 1870 is restricted to Colombia, occurring between the lower Ríos Cauca and Magdalena in the Departments of Bolívar, Antioquia and Caldas. Ateles h. hybridus occurs east from the right bank of the Río Magdalena extending into western Venezuela. Both subspecies are Critically Endangered due to habitat loss, hunting and the pet trade.

The large size, slow reproductive rate (single offspring at 3-4 year intervals) and generally low population densities of spider monkeys make them especially vulnerable to hunting. Historically, A. hybridus has suffered from habitat destruction, and only $0.67 \%$ of the current remaining $A$. hybridus distribution is protected. Most of its range has been converted to farms for agriculture and cattle.

Ateles $h$. brunneus has a small geographic range in a region where forest loss, degradation and fragmentation is widespread. Currently the remaining populations are surrounded by human populations, compounding the already high level of threat. Only $9 \%$ of their potential range remains as continuous forest. Surveys have been conducted to determine the density of this subspecies in Maceo and Puerto Berrio (Antioquia). To date just one group of eight individuals has been found in an area of 1,000 ha. A refuge remains, however, in the Serranía San Lucas in southern Bolívar, identified as an important site for the establishment of a national park. A protected area is highly necessary for this subspecies, that also would include two other threatened endemic primates, the whitefooted tamarin, Saguinus leucopus, and the woolly monkey, Lagothrix lugens.

Ateles $h$. hybridus is extremely endangered due to habitat destruction in both Colombia and Venezuela. This subspecies can be found in three protected areas in Venezuela, 
but little is known about the population densities and local threats there.

Ateles hybridus can be found in at least six zoos in Colombia, presenting problems of surplus animals and consanguinity. This species is suffering also from the pet trade; about 20 confiscated individuals are currently in residence in four rescue centers and need to be relocated. There is an urgent need for surveys to establish areas with populations of this species and to propose conservation measures. An ex situ breeding program is also necessary to maintain healthy and viable captive populations.

Erwin Palacios \& Alba Lucia Morales-Jiménez

\section{Brown-headed Spider Monkey}

Ateles fusciceps fusciceps Gray, 1866

Ecuador, Colombia

(2006)

Ateles fusciceps lives in Central and South America, from southeast Panama to Ecuador, west of the Andes along the Chocó Ecoregion. It is a diurnal species that inhabits mostly evergreen humid tropical forest. It is strictly arboreal and prefers the uppermost levels of the canopy. The species lives in groups of up to 35 individuals and its diet comprises mainly ripe fruits, but also flowers and leaves of a number of different species. The subspecies Ateles fusciceps fusciceps inhabits the Pacific coast of Ecuador and possibly southern Colombia, in an altitudinal range between 100 and $1,700 \mathrm{~m}$ above sea level. This subspecies is listed as Critically Endangered (CR) in the Red List of the IUCN as well as the Red Book of Mammals of Ecuador (Tirira 2001b), due to its restricted distribution and the small size of its natural populations. Strong hunting pressure and high deforestation rates are the most critical threats for the species; destruction of the humid tropical forest in western Ecuador has surpassed $80 \%$ of its original area. Tirira $(2003,2004)$ presented information on the historical and current distribution of the species, reporting several localities where it is locally extinct, including the type locality (Hacienda Chinipamba, west of Ibarra, Intag sector, Imbabura Province), the whole central coast of Ecuador and the forests of the Ríos Cayapas, San Miguel, Ónzole and Santiago, in the Esmeraldas Province. Currently there are only two areas known where populations of Ateles fusciceps fusciceps remain, but their ecological characteristics and conservation status are unknown. One population is found north of the Río Mira, within the protected area "Reserva Etnica Awá" close to the Colombian border; the other, to the south, is largely within the limits of another protected area: the "Reserva Ecológica Cotacachi-Cayapas" and neighboring forest (mainly in a private reserve: "Reserva Biológica Los Cedros"). There is little information on the numbers and population densities of this species in the wild. Gavilanes-Endara (2006) reported 1.2 individuals $/ \mathrm{km}^{2}$ in the Reserva Biológica Los Cedros. Its presence in Colombia is uncertain, but there is a record of A. fusciceps for Barbacoas, Nariño Department, that needs to be confirmed.

Diego Tirira \& Alba Lucia Morales-Jiménez
Peruvian Yellow-tailed Woolly Monkey

Oreonax flavicauda (Humboldt, 1812)

Peru

$(2000,2006)$

The Peruvian yellow-tailed woolly monkey, Oreonax flavicauda, is endemic to Peru, and is found only in a small area in the Tropical Andes. Oreonax flavicauda is known to persist only in primary premontane, montane and cloud forest between 1,500 to 2,700 m asl (Leo Luna 1982; Butchart et al. 1995; DeLuycker 2007). When O. flavicauda was first rediscovered in 1974, populations existed in the Departments of Loreto and La Libertad (Leo Luna 1980), but they have now been restricted to irregular, scattered parts of only two Departments, Amazonas and San Martín. There are no current estimates of remaining population numbers. Indiscriminate clearcutting of primary cloud forest is the principal threat to this species, and its habitat has been largely deforested, resulting in a greatly fragmented landscape.

Very little is known about the ecology and behavior of the yellow-tailed woolly monkey. Results from studies in the early 1980s indicated that the sizes of its multi-male/multi-female groups ranged from 5 to 18 individuals. Oreonax flavicauda has been seen to eat a variety of fruits, flowers, leaves, lichens, leaf bases of bromeliads, epiphyte roots and bulbs, and possibly insects (Leo Luna 1982; DeLuycker 2007). In a recent field survey, an unusually large group (17-20 individuals) was encountered in areas relatively close to agricultural plots, which may indicate that due to recent and on-going loss of habitat they are finding less suitable habitat areas. The species appears to be highly sensitive to alterations in its habitat (Leo Luna 1987; DeLuycker 2007). Due to the forest disturbance resulting from illegal logging, O. flavicauda decreases its use of the area (Leo Luna 1984), often retreating further into high-altitude forests far away from human settlement in order to use large tracts of forest. In 1981, it was estimated that O. flavicauda occurred in low densities, from 0.25 to 1 group per $\mathrm{km}^{2}$ (Leo Luna 1987). It is also suspected to have a large home range (DeLuycker 2007). The species is known to be present in the Río Abiseo National Park $\left(2,745 \mathrm{~km}^{2}\right)$, the Alto Mayo Protected Forest $\left(1,820 \mathrm{~km}^{2}\right)$, and the Reserved Zone Cordillera de Colán $\left(641 \mathrm{~km}^{2}\right)$, which was established in 2002 with assistance from the Asociación Peruana para la Conservación de la Naturaleza (APECO).

The current area occupied by $O$. flavicauda is unknown. In 1981, it was estimated that its potential forested habitat was at least $11,240 \mathrm{~km}^{2}$ (Leo Luna 1984). It was predicted that at least $1,600 \mathrm{~km}^{2}$ would be deforested for agriculture by 1991 (Leo Luna 1984). Projecting this value for 15 additional years, and using a very conservative similar rate of deforestation, this leaves an estimated $7,240 \mathrm{~km}^{2}$ of potential habitat area. This estimate is probably much lower, due to a high rate of migration to the area combined with unregulated land use. In addition, much or most of this forest is now highly fragmented or isolated from other tracts of forest. Oreonax flavicauda has likely declined drastically in numbers due to a big reduction in their area of occupancy and a decrease in the quality of their habitat. 
Clearing the forest for agriculture continues at an alarming rate, even in the Protected Forest of Alto Mayo (BPAM). It has been estimated that between 2,300 and 2,500 ha of forest have been destroyed in BPAM (ParksWatch, Peru). The forest of the BPAM is now considerably fragmented, a result of lack of enforcement and a substantial human population living in the Protected Forest itself. The BPAM also suffers from illegal selective logging. Members of several botanical expeditions conducted within the BPAM over the last ten years reported having never seen nor heard O. flavicauda there (M. Dillon, personal comm.). Towns that were previously connected only by footpaths are now more accessible due to road construction. For example, Vista Alegre, a town in the Department of Amazonas, and where $O$. flavicauda has been reported, has plans to build a road in the near future; the first in the region. Additionally, O. flavicauda has been extirpated from all but the most distant and isolated forests on the eastern side of the Río Alto Mayo. Illegal hunting still occurs, and if the monkeys are encountered, they are likely shot, because of their large size, conspicuousness, and trusting behavior toward humans. The species' velvety, thick, long fur, its skin and skull, and yellow genital hair-tuft are sought after as trophy items, and make this species a target for hunters even when they do not hunt it for subsistence. Infants taken when their mothers are shot are sold in markets as pets.

There is very little information on the biology and natural history of this species, resulting mainly from the difficulties imposed by the mountainous and precipitous terrain where it lives. A complete, range-wide survey of its cloud forest habitat is urgently needed to develop plans to protect the remaining populations of Oreonax flavicauda. These surveys should also include population genetic studies, to examine genetic variability and the viability of existing populations. Urgent conservation initiatives necessary for the yellow-tailed woolly monkey's survival include: increased protection within designated parks, reserves, and protected forests, which currently lack enforcement; the establishment of a contiguous area of protected forest, to create a biological corridor; the establishment of a national park or reserve in the semi-isolated Valle de los Chilchos area; control of illegal logging; purchase of land; the provision of alternative economic models for local communities living along buffer zones, in order to prevent further migration into the primary cloud forests; and the implementation of a strong conservation education plan.

Anneke M. DeLuycker \& Eckhard W. Heymann

\section{Bibliography}

\section{Greater Bamboo Lemur}

Prolemur simus

Albrecht, G. H., P. D. Jenkins and L. R. Godfrey. 1990. Ecogeographic size variation among the living and subfossil prosimians of Madagascar. Am. J. Primatol. 22: 1-50.

Arrigo-Nelson, S. J. and P. C. Wright. 2004. Survey results from Ranomafana National Park: New evidence for the effects of habitat preference and disturbance on the distribution of Hapalemur. Folia Primatol. 75: 331-334.

Dolch, R., R. D. Hilgartner, J.-N. Ndriamiary and H. Randriamahazo. 2004. "The grandmother of all bamboo lemurs": evidence for the occurrence of Hapalemur simus in fragmented rainforest surrounding the Torotorofotsy marshes, Central Eastern Madagascar. Lemur News 9: 24-26.

Godfrey, L. R. and M. Vuillaume-Randriamanantena. 1986. Hapalemur simus: Endangered lemur once widespread. Primate Conserv. (7): 92-96.

Godfrey, L. R., W. L. Jungers, E. L. Simons, P. S. Chatrath and B. Rakotosaminana. 1999. Past and present distributions of lemurs in Madagascar. In: New Directions in Lemur Studies, B. Rakotosaminana, H. Rasimanana, J. U. Ganzhorn and S. M. Goodman (eds.), pp.19-53. Kluwer Academic/ Plenum Publishers, New York.

Godfrey, L. R., E. L. Simons, W. L. Jungers, D. D. DeBlieux and P. S. Chatrath. 2004. New discovery of subfossil Hapalemur simus, the greater bamboo lemur, in western Madagascar. Lemur News 9: 9-11.

Goodman, S. M., V. R. Razafindratsia, V. Schütz and R. Ratsimbazafy. 2001b. Les lémuriens. In: Inventaire biologique du Parc National de Ranomafana et du couloir forestier qui la relie au Parc National d'Andringitra, S. M. Goodman and V. R. Razafindratsia (eds.). Centre d'Information et du Documentation Scientifique et Technique, Antananarivo 17: 231-243.

Irwin, M. T., S. E. Johnson and P. C. Wright. In press. The state of lemur conservation in southeastern Madagascar: Population and habitat assessments for diurnal lemurs using surveys, satellite imagery and GIS. Oryx 39.

Macedonia, J. M. and K. F. Stanger. 1994. Phylogeny of the Lemuridae revisited: Evidence from communication signals. Folia Primatologica 63: 1-43.

Meier, B. 1987. Preliminary report of a field study on Lemur rubriventer and Hapalemur simus (nov. species) in Ranomafana-Ifanadiana 312 Faritany Fianarantsoa, Madagascar, July 1986-January 1987 . Unpublished report to Ministry of Scientific Research, Antananarivo.

Meier, B. and Y. Rumpler. 1987. Preliminary survey of Hapalemur simus and of a new species of Hapalemur in eastern Betsileo, Madagascar. Primate Conserv.(8): 40-43.

Rakotosamimanana, B., R. R. Ralaiarison, R. C. Ralisoamalala, T. M. Rasolofoharivelo, V. Raharimanantsoa, R. M. Randrianarison, J. G. Rakotondratsimba, D. R. W. Rasolofoson, E. O. Rakotonirainy and T. M. Randriamboavonjy. 2004. Comment et pourquoi les lémuriens 
diurnes disparaissent peu à peu dans les forêts d'Ambato et de Moramanga (région de Moramanga) Madagascar? Lemur News 9: 19-24.

Rumpler, Y., S. Warter, B. Ishak and B. Dutrillaux. 1989. Chromosomal evolution in primates. Hum. Evol. 4: 157-170.

Schwarz, E. 1931. A revision of the genera and species of Madagascar Lemuridae. Proc. Zool. Soc. Lond. 1931: $399-428$.

Stanger-Hall, K. F. 1997. Phylogenetic affinities among the extant Malagasy lemurs (Lemuriformes) based on morphology and behavior. J. Mammal. Evol. 4: 163-194.

Sterling, E. J. and M. G. Ramaroson. 1996. Rapid assessment of the primate fauna of the eastern slopes of the Rèserve Naturelle Intégrale d'Andringitra, Madagascar. In: A Floral and Faunal Inventory of the Eastern Slopes of the Rèserve Naturelle Intégrale d'Andringitra, Madagascar, with Reference to Elevational Variation, S. M. Goodman (ed.). Fieldiana: Zool., new series 85: 293-305.

Tan, C. L. 1999. Group composition, home range size, and diet in three sympatric bamboo lemur species (genus Hapalemur) in Ranomafana National Park, Madagascar. Int.J. Primatol. 20: 547-566.

Tan, C. L. 2000. Behavior and ecology of three sympatric bamboo lemur species (genus Hapalemur) in Ranomafana National Park, Madagascar. Ph. D. thesis, State University of New York, Stony Brook.

Vuillaume-Randriamanantena, M., L. R. Godfrey and M. R. Sutherland. 1985. Revision of Hapalemur (Prohapalemur) gallieni (Standing 1905). Folia Primatol. 45: 89-116.

Wilson, J. M., P. D. Stewart and S. V. Fowler. 1988. Ankarana-a rediscovered nature reserve in northern Madagascar. Oryx 22: 163-171.

Wright, P. C., P. S. Daniels, D. M. Meyers, D. J. Overdorff and J. Rabesoa. 1987. A census and study of Hapalemur and Propithecus in southeastern Madagascar. Primate Conserv. (8): 84-87.

\section{White-collared Lemur}

\section{Eulemur albocollaris}

CBSG. 2002. Evaluation et Plans de Gestion pour la Conservation (CAMP) de la Faune Madagascar: Lémuriens, Autres Mammifères, Reptiles et Amphibiens, Poissons d'eau douce et Evaluation de la Viabilité des Populations et des Habitats des Hypogeomys antimena (Vositse). IUCN/SSC Conservation Breeding Specialist Group (CBSG), Apple Valley, Minnesota.

Djletati, R., B. Brun and Y. Rumpler. 1997. Meiotic study of hybrids in the genus Eulemur and taxonomic considerations. Am. J. Primatol. 42: 235-245.

Groves, C. P. 2001. Primate Taxonomy. Smithsonian Institution Press, Washington, DC.

Irwin, M. T., S. E. Johnson and P. C. Wright. In press. The state of lemur conservation in southeastern Madagascar: Population and habitat assessments for diurnal lemurs using surveys, satellite imagery and GIS. Oryx 39.
Johnson, S. E. 2002. Ecology and speciation in brown lemurs: white-collared lemurs (Eulemur albocollaris) and hybrids (Eulemur albocollaris $\mathrm{x}$ Eulemur fulvus rufus) in southeastern Madagascar. Ph. D. thesis, University of Texas, Austin.

Johnson, S. E. 2006. Evolutionary divergence in the brown lemur species complex. In: Lemurs: Ecology and Adaptation, L. Gould and M. L. Sauther (eds.), pp.187-210. Springer, New York.

Johnson, S. E. and D. J. Overdorff. 1999. Census of brown lemurs (Eulemur fulvus spp.) in southeastern Madagascar: Methods testing and conservation implications. Am. J. Primatol. 47: 51-60.

Johnson, S. and Y. Wyner. 2000. Notes on the biogeography of Eulemur fulvus albocollaris. Lemur News 5: 25-28.

Mittermeier, R. A., W. R. Konstant, F. Hawkins, E. E. Louis Jr., O. Langrand, J. Ratsimbazafy, R. Rasoloarison, J. U. Ganzhorn, S. Rajaobelina, I. Tattersall and D. M. Meyers. 2006. Lemurs of Madagascar, 2nd Ed., Conservation International, Washington, DC.

Pastorini, J., M. R. J. Forstner and R. D. Martin. 2000. Relationships among brown lemurs (Eulemur fulvus) based on mitochondrial DNA sequences. Molec. Phylogenet. Evol. 16: $418-429$.

Petter, J.-J. and A. Petter-Rousseaux. 1979. Classification of the prosimians. In: The Study of Prosimian Behavior, G. A. Doyle and R. D. Martin (eds.), pp.359-409. Academic Press, London.

Rumpler, Y. 1975. The significance of chromosomal studies in the systematics of the Malagasy lemurs. In Lemur Biology, Vol. 1, I. Tattersall and R. W. Sussman (eds.), pp.25-40. Plenum Press, New York.

Sterling, E. J. and M. G. Ramaroson. 1996. Rapid assessment of the primate fauna of the eastern slopes of the Rèserve Naturelle Intégrale d'Andringitra, Madagascar. In: A Floral and Faunal Inventory of the Eastern Slopes of the Rèserve Naturelle Intégrale d'Andringitra, Madagascar: With Reference to Elevational Variation, S. M. Goodman (ed.). Fieldiana: Zool., new series 85: 293-305.

Tattersall, I. 1982. The Primates of Madagascar. Columbia University Press, New York.

Wyner, Y., R. Absher, G. Amato, E. Sterling, R. Stumpf, Y. Rumpler and R. DeSalle. 1999. Species concepts and the determination of historic gene flow patterns in the Eulemur fulvus (brown lemur) complex. Biol. J. Linn. Soc. 65:39-56.

Wyner, Y. M., S. E. Johnson, R. M. Stumpf and R. DeSalle. 2002. Genetic assessment of a white-collared $\mathrm{x}$ red-fronted lemur hybrid zone at Andringitra, Madagascar. Am. J. Primatol. 57: 51-66.

\section{Silky Sifaka}

\section{Propithecus candidus}

Duckworth, J. W., M. I. Evans, A. F. A. Hawkins, B. J. Stafford and R. J. Wilkinson. 1995. The lemurs of Marojejy Strict Reserve, Madagascar: a status overview with notes on ecology and threats. Int. J. Primatol. 16: 545-559. 
Garbutt, N. 1999. Mammals of Madagascar. Yale University Press, New Haven.

Garbutt, N. 2007. Mammals of Madagascar: A Complete Guide. A\&C Black Publishers Ltd., London.

Goodman, S.M. 2000. Description of the Parc National de Marojejy, Madagascar, and the 1996 Biological Inventory of the Reserve. Fieldiana Zool., new series 97: 1-18.

Goodman, S. M., M. J. Raherilalao, D. Rakotomalala, D., A. Raselimanana, H. Schütz and V. Soarimalala. 2003. Les Lémuriens. In: Nouveaux Résultats d'Inventaires Biologiques Faisant Référence à l'Altitude dans la Région des Massifs Montagneux de Marojejy et d'AnjanaharibeSud, S. M. Goodman and L. Wilmé (eds.), pp.279-286. Recherches pour le Développement, série sciences biologiques no. 19, Centre d'Information et de Documentation Scientifique et Technique, Antananarivo.

Kelley, E. and Mayor, M. I. 2002. Preliminary study of the silky sifaka (Propithecus diadema candidus) in northeast Madagascar. Lemur News (7): 16-18.

Mittermeier, R. A., W. R. Konstant, F. Hawkins, E. E. Louis Jr., O. Langrand, J. Ratsimbazafy, R. Rasoloarison, J. U. Ganzhorn, S. Rajaobelina., I. Tattersall, I. and D. M. Meyers. 2006. Lemurs of Madagascar. 2nd edition. Tropical Field Guide Series, Conservation International, Washington DC.

Patel, E. R., J. J. Marshall and H. Parathian. 2005. Silky sifaka (Propithecus candidus) conservation education in northeastern Madagascar. Lab. Prim. Newsl. 44(3): 8-11.

Patel, E. R. 2005. Silky sifaka (Propithecus candidus) predation by a fossa (Cryptoprocta ferox). Lemur News (10): $25-27$.

Patel, E. R. 2006. Activity budget, ranging, and group size in silky sifakas (Propithecus candidus). Lemur News (11): 42 -45 .

Patel, E. R. 2007. Non-maternal infant care in wild silky sifakas (Propithecus candidus). Lemur News (12). In press.

Patel, E. R. Submitted. Logging of rare rosewood and palisandre (Dalbergia spp.) within Marojejy National Park, Madagascar.

Rakotondratsimba, J. G., D. Rasolofoson, O. Rakotonirainy and J. Ratsimbazafy. 2007. Le bloc forestier de Makira charnière de lémuriens. Lemur News (12). In press.

Schmid, J. and R. Smolker. 1998. Lemurs of the Reserve Special d'Anjanaharibe-Sud, Madagascar. Fieldiana Zool., new series 90: 227-240.

Sterling, E. and K. McFadden. 2000. Rapid census of lemur populations in Parc National de Marojejy, Madagascar. Fieldiana Zool., new series 97: 265-274.

Tattersall, I. 1982. The Primates of Madagascar. Columbia University Press, New York.

\section{Sahamalaza Sportive Lemur}

Lepilemur sahamalazensis

Andriaholinirina, N., J.-L. Fausser, C. Roos., D. Zinner, U. Thalmann, C. Rabarivola, I. Ravoarimanana, J. U. Ganzhorn, B. Meier, R. Hilgartner, L. Walter., A. Zaramody,
C. Langer, T. Hahn, E. Zimmermann, E., U. Radespiel, M. Craul, J. Tomiuk, I. Tattersall and Y. Rumpler. 2006. Molecular phylogeny and taxonomic revision of the sportive lemurs (Lepilemur, Primates). BMC Evol. Biol. 6, 17.

Birkinshaw, C. R. 2004. Priority Areas for Plant Conservation. Ravintsara 2(1):14-15.

Lernould, J.-M. 2006. AEECL zoos involved in the discovery of four new lemur species. EAZA News (55): 14-15.

MAB. 2001. Biosphere Reserve Information, Madagascar: Sahamalaza - Iles Radama. [Online]. Retrieved on 11 December 2006 from http://www2.unesco.org/mab/br/ brdir/directory/biores.asp? code $=\mathrm{MAG}+02 \& \operatorname{mode}=$ all .

Olivieri, G. L., M. Craul and U. Radespiel. 2005. Inventaire des lémuriens dans 15 fragments de forêt de la province de Mahajanga. Lemur News 10: 11-16.

Rabarivola, C., A. Zaramody, J.-L. Fausser, N. Andriaholinirina, C. Roos, D. Zinner, M. Hauwy and Y. Rumpler Y. 2006. Cytogenetic and molecular characteristics of a new species of sportive lemur from northern Madagascar. Lemur News 11, 45-49.

Schwitzer, C., N. Schwitzer, G. H. Randriatahina, C. Rabarivola and W. Kaumanns. 2006. "Programme Sahamalaza": New perspectives for the in situ and ex situ study and conservation of the blue-eyed black lemur (Eulemur macaco flavifrons) in a fragmented habitat. In Proceedings of the German-Malagasy Research Cooperation in Life and Earth Sciences, C. Schwitzer, S. Brandt, O. Ramilijaona, M. Rakotomalala Razanahoera, D. Ackermand, T. Razakamanana \& J. U. Ganzhorn (eds.), pp.135-149. Concept Verlag, Berlin.

\section{Rondo dwarf galago}

Galagoides rondoensis

Ahrends, A. 2005. Pugu Forest: going, going The Arc Journal 17: 23.

Bearder, S. K., L. Ambrose, C. Harcourt, P. Honess, A. Perkin, S. Pullen, E. Pimley and N. Svoboda. 2003. Speciestypical patterns of infant care, sleeping site use and social cohesion among nocturnal primates in Africa. Folia Primatol. 74: 337-354.

Burgess, N. D. and G. P. Clarke. 2000. Coastal Forests of Eastern Africa. IUCN - The World Conservation Union, Gland, Switzerland, and Cambridge, UK.

Doggart, N. (ed.). 2003. Pande Game Reserve: A Biodiversity Survey. Tanzania Forest Conservation Group, Technical Paper 7. Dar es Salaam, Tanzania.

Honess, P. E. 1996a. New primatological discoveries in Tanzania: a discussion about speciation. Social Biology and Human Affairs 61 (1): 7-18.

Honess, P. E. 1996b. Speciation among galagos (Primates, Galagidae) in Tanzanian forests. PhD thesis, Oxford Brookes University, Oxford, UK.

Honess, P. E. and S. K. Bearder. 1996. Descriptions of the dwarf galago species of Tanzania. African Primates 2: 75-79.

IUCN. 2006. 2006 IUCN Red List of Threatened Species. IUCN - The World Conservation Union, Species Survival 
Commission (SSC), Gland, Switzerland, and Cambridge, UK. Website: <www.iucnredlist.org > . Accessed: 5 March 2007.

Kingdon, J. 1997. The Kingdon Field Guide to African Mammals. Academic Press, London.

Perkin, A. 2000. A Field Study of the Conservation Status and Diversity of Galagos in Zareninge Forest, Coast Region, Tanzania. Report of WWF-Tanzania, Dar-es-Salaam.

Perkin, A. 2003. Mammals. In: Pande Game Reserve: A Biodiversity Survey, N. Doggart (ed.) pp.95. Tanzania Forest Conservation Group, Technical Paper 7. Dar es Salaam, Tanzania.

Perkin, A. 2004. Galagos of the Coastal Forests and Eastern Arc Mtns. of Tanzania -Notes and Records. Tanzania Forest Conservation Group, Technical Paper 8. Dar es Salaam, Tanzania.

\section{Roloway Guenon}

\section{Cercopithecus diana roloway}

Groves, C. P. 2001. Primate Taxonomy. Smithsonian Institution Press, Washington, DC.

Grubb, P., T. M. Butynski, J. F. Oates, S. K. Bearder, T. R. Disotell, C. P. Groves and T. T. Struhsaker. 2003. An assessment of the diversity of African primates. Int. J. Primatol. 24: $1301-1357$.

Kone. I. 2004. Report on recent primate surveys in the southeast of Ivory Coast. Report, Conservation des Espèces et des Populations Animales (CEPA), Schlierbach, France.

Kone, I. and K. B. Akpatou.2005. Recherche en Cote d'Ivoire de trios singes gravement menaces d'extinction. CEPA Magazine 12: 11-13.

Magnuson, L. 2003. Final Brief: Ecology and Conservation of the Roloway Monkey in Ghana. Unpublished report to the Wildlife Division of Ghana, Forestry Commission, Ghana.

McGraw, W. S. 1998a. Three monkeys nearing extinction in the forest reserves of eastern Cote d'Ivoire. Oryx 32: $233-236$.

McGraw, W. S. 1998b. Surveys of endangered primates in the forest reserves of eastern Cote d'Ivoire. African Primates 3(1-2): $22-25$.

McGraw, W. S. 2005. Update on the search for Miss Waldron's red colobus monkey (Procolobus badius waldroni). Int. J. Primatol.26(3): 605-619.

Oates, J. F. 1996. African Primates: Status Survey and Conservation Action Plan. Revised Edition. IUCN/SSC Primate Specialist Group, Gland, Switzerland. 80pp.

Oates, J. F. 2006. Primate Conservation in the Forests of Western Ghana: Field Survey Results, 2005-2006. Report to the Wildlife Division, Forestry Commission, Ghana.

Oates, J. F., T. T. Struhsaker and G. H. Whitesides. 1996/1997. Extinction faces Ghana's red colobus and other locally endemic subspecies. Primate Conserv. (17): 138-144.

Struhsaker, T. T. and J. F. Oates. 1995. The biodiversity crisis in southwestern Ghana. African Primates 1: 5-6.

\section{Bioko Red Colobus}

Procolobus pennantii pennantii

Butynski, T. M. and S. H. Koster. 1994. Distribution and conservation status of primates in Bioko Island, Equatorial Guinea. Biodiv. Conserv. 3: 893-909.

Gautier-Hion, A., M. Colyn. and J.-P. Gautier. 1999. Histoire Naturelle des Primates d'Afrique Centrale. ECOFAC, Libreville.

Hearn, G., W. A. Morra and T. M. Butynski. 2006. Monkeys in trouble: The rapidly deteriorating conservation status of the monkeys on Bioko Island, Equatorial Guinea. Report, Bioko Biodiversity Protection Program, Glenside, Pennsylvania. Website: $<$ http://www.bioko.org $>$.

Kone, I. 2004. Report on recent primate surveys in the southeast of Ivory Coast. Unpublished report to Conservation des Espèces et des Populations Animales (CEPA), Schlierbach, France.

McGraw, W. S. 1998. Three monkeys nearing extinction in the forest reserves of eastern Côte d'Ivoire. Oryx 32: $233-236$.

McGraw, W. S. 2005. Update on the search for Miss Waldron's red colobus monkey (Procolobus badius waldroni). Int. J. Primatol. 26: 605-619.

McGraw, W. S. and J. F. Oates. 2002. Evidence for a surviving population of Miss Waldron's red colobus. Oryx 36: $223-226$

Oates, J. F. 1994. The natural history of African colobines. In: Colobine Monkeys: Their Ecology, Behaviour and Evolution, A. G. Davies and J. F. Oates (eds.), pp.75-128. Cambridge University Press, Cambridge.

Oates, J. F. 1996. African Primates: Status Survey and Conservation Action Plan. Revised edition. IUCN, Gland, Switzerland.

Oates, J. F., T. T. Struhsaker and G. H. Whitesides. 1996/1997. Extinction faces Ghana's red colobus and other locally endemic subspecies. Primate Conserv. (17): 138-144.

Oates J. F., M. Abedi-Lartey, W. S. McGraw, T. T. Struhsaker and G. H. Whitesides. 2000. Extinction of a West African red colobus monkey. Conserv. Biol. 14: 1526-1532.

Oates, J. F., R. A. Bergl and J. M. Linder. 2004. Africa's Gulf of Guinea forests: Biodiversity patterns and conservation priorities. Advances in Applied Biodiversity Science 6: 1-90. Center for Applied Biodiversity Science, Conservation International, Washington, DC.

Struhsaker, T. T. 1999. Primate communities in Africa: The consequence of long-term evolution or the artifact of recent hunting? In: Primate Communities, J. G. Fleagle, C. Janson and K. E. Reed (eds.), pp.289-294. Cambridge University Press, Cambridge.

Struhsaker, T. T. 2005. The conservation of red colobus and their habitats. Int. J. Primatol. 26: 525-538.

Waltert, M., Lien, K. Faber and M. Muhlenberg, M. 2002. Further declines of threatened primates in the Korup Project Area, south-west Cameroon. Oryx 36: $257-265$ 


\section{Tana River Red Colobus}

\section{Procolobus rufomitratus}

Butynski, T. M. and G. Mwangi. 1995. Census of Kenya's endangered red colobus and crested mangabey. African Primates 1: 8-10.

Butynski, T. M. and G. Mwangi. 1994. Conservation status and distribution of the Tana River red colobus and crested mangabey. Report to Zoo Atlanta, Georgia, Kenya Wildlife Service, National Museums of Kenya, Institute of Primate Research, and East African Wildlife Society, Nairobi, Kenya. 68pp.

Luke, Q., R. Hatfield and P. Cunneyworth. 2005. Rehabilitation of the Tana Delta Irrigation Project Kenya: An Environemtal Assessment. Report to Critical Ecosystem Partnership Fund (CEPF), Conservation International, Arlington, VA. Website: <http://www.cepf.net/ ImageCache/cepf/content/pdfs/final_2etdip_5fenvironm ental_5fassessment_2epdf $/ \mathrm{v} 1 /$ final.tdip_5fenvironmental 5fassessment.pdf $>$. Accessed 23 February, 2007.

Marsh, C. W. 1985. A survey of Tana River primates. Unpublished report to the Institute of Primate Research, Nairobi, Kenya.

Mbora, D. N. M. and W. C. McGrew. 2002. Extra-group sexual consortship in the Tana River red colobus (Procolobus rufomitratus)? Folia Primatol. 73: 210-213.

Mbora, D. N. M. and D. B. Meikle. 2004. Forest fragmentation and the distribution, abundance and conservation of the Tana River red colobus (Procolobus rufomitratus). Biol. Conserv. 118: 67-77.

Mbora, D. N. M. and D. B. Meikle. 2004. The value of unprotected habitat in conserving endangered species: Case study of the Tana River red colobus in eastern Kenya. Biol. Conserv. 120: 91-99.

Mbora, D. N. M. and E. Munene. 2006. Gastrointestinal parasites of critically endangered primates endemic to Tana River Kenya; the Tana River red colobus (Procolobus rufomitratus) and the crested mangabey (Cercocebus galeritus). J. Parasitol. 92: 928-932.

Wieczkowski, J. and D. N. M. Mbora. 2000. Increasing threats to the conservation of endemic endangered primates and forests of the lower Tana River, Kenya. African Primates $4(1-2): 32-40$.

Wieczkowski, J., D. N. M. Mbora, A. Kariuki, A. and S. Strum. 2001. Tana River Primate and Habitat Monitoring Project. Report to Margot Marsh Biodiversity Foundation, Great Falls, Virginia. 13pp.

\section{Miss Waldron's Red Colobus}

Procolobus badius waldroni

Groves, C. P. 2001. Primate Taxonomy. Smithsonian Institution Press, Washington, DC.

Grubb, P., T. M. Butynski, J. F. Oates, S. K. Bearder, T. R. Disotell, C. P. Groves and T. T. Struhsaker. 2003. An assessment of the diversity of African primates. Int. J. Primatol. 24: $1301-1357$
Grubb, P. and C. B. Powell. 1999. Discovery of red colobus monkeys (Procolobus badius) in the Niger Delta with the description of a new and geographically isolated subspecies. J. Zool., Lond. 248: 67-73.

Kone, I. 2004. Report on recent primate surveys in the southeast of Ivory Coast. Report, Conservation des Espèces et des Populations Animales (CEPA), Schlierbach, France.

Kone, I. and K. B. Akpatou. 2005. Identification des sites abritant encore les singes Cercopithecus diana roloway, Cercocebus atys lunulatus et Piliocolobus badius waldroni en Cote d'Ivoire. Report, Conservation des Espèces et Populations Animales (CEPA), Schlierbach, France.

Kone, I., D. Coulibaly, K. Bene, A. Bitty, A. Koffi, A. Boko and R. Kouadio. 2007. Initiation of a community based conservation system in southeastern Cote d'Ivoire for the probable last refuge for the Miss Waldron's red colobus. Report, West African Primates Conservation Action, Abidjan, Côte d'Ivoire.

McGraw, W. S. 1998. Three monkeys nearing extinction in the forest reserves of eastern Cote d'Ivoire. Oryx 32: $233-236$

McGraw, W. S. 2005. Update on the search for Miss Waldron's red colobus monkey (Procolobus badius waldroni). Int. J. Primatol. 26(3): 605-619.

McGraw, W. S. and J. F. Oates. 2002. Evidence for a surviving population of Miss Waldron's red colobus. Oryx 36: $223-226$

Oates, J. F. 1996. African Primates: Status Survey and Conservation Action Plan. Revised Edition. IUCN/SSC Primate Specialist Group, Gland, Switzerland. 80pp.

Oates, J. F. 2006. Primate Conservation in the Forests of Western Ghana: Field Survey Results, 2005-2006. Report to the Wildlife Division, Forestry Commission, Ghana.

Oates, J. F., T. T. Struhsaker and G. H. Whitesides. 1996/1997. Extinction faces Ghana's red colobus and other locally endemic subspecies. Primate Conserv. (17): $138-144$.

Oates, J. F., M. Abedi-Lartey, W. S. McGraw, T. T. Struhsaker and G. H. Whitesides. 2000. Extinction of a West African red colobus monkey. Conserv. Biol. 14: 1526-1532.

Struhsaker, T. T. 1999. Primate communities in Africa: The consequence of long-term evolution or the artifact of recent hunting? In: Primate Communities, J. G. Fleagle, C. Janson and K. E. Reed (eds.), pp.289-294. Cambridge University Press, Cambridge, UK.

Struhsaker, T. T. 2005. The conservation of red colobus monkeys (Procolobus) and their habitats. Int. J. Primatol. 26(3): 525-538.

Struhsaker, T. T. and J. F. Oates. 1995. The biodiversity crisis in southwestern Ghana. African Primates 1: 5-6.

Wolfheim, J. H. 1983. Primates of the World. University of Washington Press, Seattle. 


\section{Kipunji}

Rungwecebus kipunji

Davenport, T. R. B. 2005. Finding kipunji. Africa Geographic 13(7): $56-61$.

Davenport, T. R. B. 2006. Plants, primates and people. Conservation in the Southern Highlands of Tanzania. Miombo (28):7-8.

Davenport, T. R. B. and T. Jones. 2005. The highland mangabey - Africa's first new monkey for 20 years further illustrates the exceptional value of Tanzania's forests. Arc Journal 20: 1-6.

Davenport, T. R. B., T. Jones, N, E. Mpunga, S. J. Machaga, D. W. De Luca, R. Laizzer, A. Mndeme and W. S. Mwakilema. 2005. The highland mangabey Lophocebus kipunji, Africa's 'newest' monkey. Unpublished Proceedings of the Fifth Annual Scientific Conference, Tanzania Wildlife Research Institute, Arusha.

Davenport, T. R. B., W. T. Stanley, E. J. Sargis, D. W. De Luca, N. E. Mpunga, S. J. Machaga, and L. E. Olson. 2006. A new genus of African monkey, Rungwecebus: morphology, ecology, and molecular phylogenetics. Science 312: $1378-1381$.

Davenport, T. R. B., D. W. De Luca, T. Jones., N. E. Mpunga, S. J. Machaga and G. Picton Phillipps. Submitted. The kipunji Rungwecebus kipunji of southern Tanzania: first census and assessments of distribution and conservation status.

Davenport, T. R. B., D. W. De Luca, S. J. Machaga and N. E. Mpunga. In preparation. Diet and feeding behaviour in the kipunji Rungwecebus kipunji.

De Luca, D.W., T. R. B. Davenport, G. Picton Phillipps, S. J. Machaga and N. E. Mpunga. Submitted. Home range and activity patterns in the kipunji Rungwecebus kipunji.

Ehardt, C. L. and T. M. Butynski. 2006a. Sanje River mangabey. In: Primates in Peril: The World's 25 Most Endangered Primates 2004-2006, R. A. Mittermeier, C. Valladares-Pádua, A. B. Rylands, A. A. Eudey, T. M. Butynski, J. U. Ganzhorn, R. Kormos, J. M. Aguiar and S. Walker (eds.), Primate Conserv. (20): 7-8.

Ehardt, C. L. and T. M. Butynski. 2006b. The recently described highland mangabey Lophocebus kipunji (Cercopithecoidea, Cercopithicinae): current knowledge and conservation assessment. Primate Conserv. (21): 81-88.

Ehardt, C. L., T. P. Jones and T. M. Butynski. 2005. Protective status, ecology and strategies for improving conservation of Cercocebus sanjei in the Udzungwa Mountains, Tanzania. International Journal of Primatology 26: 557-582.

Hoffmann, M. 2006. African Primate Red List Workshop: assessing the conservation status of African primates. Report, Conservation International, Washington, DC, and Margot Marsh Biodiversity Foundation, Virginia. 10pp.

Homewood, K. M. and W. A. Rodgers. 1981. A previously undescribed mangabey from southern Tanzania. Int. J. Primatol. 2: 47-55.

IUCN. 2006. 2006 IUCN Red List of Threatened Species. Website: <www.iucnredlist.org>. IUCN - The World
Conservation Union, Species Survival Commission (SSC), Gland, Switzerland, and Cambridge, UK. Accessed 20 March 2007.

Jones, T. P., C. L. Ehardt, T. M. Butynski, T. R. B. Davenport, N. E. Mpunga, S. J. Machaga and D. W. De Luca. 2005. The highland mangabey Lophocebus kipunji: a new species of African monkey. Science 308: 1161-1164.

Olson, L. E., W. T. Stanley, K. Hildebrandt, E. Sargis and T. R. B. Davenport. Submitted. Additional molecular data support the phylogenetic position and taxonomic status of Rungwecebus kipunji (Primates: Cercopithecidae).

\section{Cross River Gorilla}

Gorilla gorilla diehli

Bassey, A. E. and J. F. Oates (eds.). 2001. Proceedings of the International Workshop And Conference on the Conservation of the Cross River Gorillas, Calabar, Nigeria, April $6-9,2001$.

Bergl, R. A. 2006. Conservation Biology of the Cross River Gorilla (Gorilla gorilla diehli). PhD thesis, Graduate Center, City University of New York, New York.

Bergl, R. A. and L. Vigilant. 2007. Genetic analysis reveals population structure and recent migration within the highly fragmented range of the Cross River gorilla (Gorilla gorilla diehlii). Molec. Ecol. 16: 501-516.

Groves, C. P. 2005. A note on the affinities of the Ebo Forest gorilla. Gorilla Journal (31): 19-21.

Groves, J. L. 1999. Gorillas in the Takamanda Forest Reserve. Gorilla Journal. (18): 17-18.

Groves, J. L. 2001. Gorillas of Takamanda, Mone and Mbulu forest, Cameroon. Gorilla Journal (22): 27-29.

McFarland, K. L. 2007. Ecology of Cross River Gorillas (Gorilla gorilla diehli) on Afi Mountain, Cross River State, Nigeria. PhD thesis, Graduate Center, City University of New York, New York.

Morgan, B. J. 2004. The gorillas of the Ebo Forest, Cameroon. Gorilla Journal (28): 12-14.

Morgan, B. J. and J. L. Sunderland-Groves. 2006. The CrossSanaga gorillas: The northernmost gorilla populations. Gorilla Journal (32): 16-18.

Morgan, B. J., C. Wild and A. Ekobo. 2003. Newly discovered gorilla population in the Ebo Forest, Littoral Province, Cameroon. Int. J. Primatol. 24(5): 1129-1137.

Oates, J. F., D. White, E. L. Gadsby and P. O. Bisong. 1990. Conservation of gorillas and other species. Appendix 1 to Cross River National Park (Okwangwo Division): Plan for Developing the Park and Its Support Zone. World Wide Fund for Nature, Godalming, UK.

Oates, J. F., K. L. McFarland, J. L. Groves, R. A. Bergl, J. M. Linder and T. R. Disotell. 2003. The Cross River gorilla: Natural history and status of a neglected and critically endangered subspecies. In: Gorilla Biology: A Multidisciplinary Perspective, A. B. Taylor and M. L. Goldsmith (eds.), pp.472-497. Cambridge University Press, Cambridge, UK. 
Oates, J. F., R. A. Bergl and J. M. Linder. 2004. Africa's Gulf of Guinea Forests: Biodiversity Patterns and Conservation Priorities. Advances in Applied Biodiversity Science (6): 1-90. Center for Applied Biodiversity Science, Conservation International, Washington, DC.

Oates, J. F., J. Sunderland-Groves, R. Bergl, A. Dunn, A. Nicholas, E. Takang, F. Omeni, I. Imong, R. Fotso, L. Nkembi and L. Williamson (eds.). 2007. Regional Action Plan for the Conservation of the Cross River Gorilla (Gorilla gorilla diehli). Wildlife Conservation Society, New York, and IUCN/SSC Primate Specialist Group, Arlington, VA.

Sarmiento, E. E. 2003. The Cross River gorilla: The most endangered gorilla subspecies. Primate Conserv. (19): $65-72$.

Sarmiento, E. E. and J. F. Oates. 2000. Cross River gorillas: A distinct subspecies, Gorilla gorilla diehli Matschie, 1904. Am. Mus. Nov. (3304): 1-55.

Sunderland-Groves, J. L. and J. F. Oates 2003. Priority conservation actions for Cross River gorillas in Cameroon and Nigeria. Report, Wildlife Conservation Society, New York.

Sunderland-Groves, J. L. and B. Jaff. (eds.). 2004. Developing a Conservation Strategy for the Cross River Gorilla. Proceedings of the $2^{\text {nd }}$ International Workshop and Conference on the Conservation of the Cross River Gorilla. Wildlife Conservation Society.

Sunderland-Groves, J. L., F. Maisels and A. Ekinde. 2003. Surveys of the Cross River gorilla and chimpanzee populations in Takamanda Forest Reserve, Cameroon. In: Takamanda: the Biodiversity of an African Rainforest. J. A. Comiskey, T. C. H. Sunderland and J. L. Sunderland-Groves (eds.), pp. 129-140. Smithsonian Institution Monitoring and Assessment of Biodiversity Program Series 8. Smithsonian Institution, Washington DC.

\section{Siau Island Tarsier}

Tarsius sp.

Brandon-Jones, D., A. A. Eudey, T. Geissmann, C. P. Groves, D. J. Melnick. J. C, Morales, M. Shekelle and C.-B. Stewart. 2004. Asian primate classification. Int. J. Primatol. 25(1): $97-164$.

Fitch-Snyder, H. 2003. History of captive tarsier conservation. In: Tarsiers: Past, Present, and Future, P. C. Wright, E. L. Simons and S. Gursky (eds.), pp.277-295. Rutgers University Press, New Brunswick, NJ.

Meyer, A. B. 1897. Säugethiere vom Celebes- und Philippinen-Archipel, I. Abhandlungen und Berichte der Kaiserlich Zoologische und Anthropologische-Ethnologische Museum zu Dresden 6(I-VIII): 1-36.

Riley, J. 2002. Mammals on the Sangihe and Taluad Islands, Indonesia, and the impact of hunting and habitat loss. Oryx 36(3): 288-296.

Shekelle, M. and S. M. Leksono. 2004. Rencana Konservasi di Pulau Sulawesi: Dengan Menggunakan Tarsius Sebagai 'Flagship Taxon'. Biota IX(1): 1-10.
Shekelle, M., M. Meier, M. Indrawan, I. Maryanto, A. Salim, J. Supriatna, N. Andayani and Wirdateti. 2007. When 'not extinct' is not good news: Conservation in the Sangihe Islands. Conserv. Biol. 21(1): 4-6.

Shekelle M. and A. Salim. In press. An acute conservation threat to two tarsier species in the Sangihe Island Chain (North Sulawesi, Indonesia). Oryx.

Shekelle, M. et al. In preparation. Tarsius xxxxxxx: a new tarsier species from Siau Island, North Sulawesi [species name withheld prior to publication].

Whitten, T. 2006. Cerulean Paradise-Flycatcher not extinct: Subject of the first cover lives. Conserv. Biol. 20(3): 918-920.

Whitten, T., S. D. Nash and K. D. Bishop. 1987. One or more extinctions from Sulawesi? Conserv. Biol. 1: 42-48.

\section{Horton Plains Slender Loris, Ceylon Mountain Slender Loris}

Loris tardigradus nycticeboides

Bernede, L. In preparation. A Radio-Tracking Study of the Social and Behavioural Ecology of the Red Slender Loris (Loris tardigradus tardigradus) in Masmullah Proposed Forest Reserve, Sri Lanka. Phd Thesis, Oxford Brookes University, Oxford, UK.

Hill, W. C. O. 1942. The slender loris of the Horton Plains, Ceylon. J. Bombay Nat. Hist. Soc. 43: 73-78.

Nekaris, K. A. I. 2003. Rediscovery of the slender loris in Horton Plains National Park, Sri Lanka. Asian Primates 8(03): $1-7$.

Nekaris, K. A. I. and J. Jayewardene. 2003. Pilot study and conservation status of the slender loris (Loris tardigradus and L. lydekkerianus) in Sri Lanka, Primate Conservation (19): 83-90.

Nekaris, K. A. I. and J. Jayewardene. 2004. Survey of the slender loris (Primates, Lorisidae Gray, 1821: Loris tardigradus (Linnaeus, 1758) and Loris lydekkerianus Cabrera, 1908 in Sri Lanka. J. Zool., Lond. 262: 1-12.

Nekaris, K. A. I., S. N. Gamage and B. V. P. Perera. In press. Loris tardigradus nycticeboides. In: Conservation International's Field Guide to the Primates of South Asia.

Phillips, W. W. A. 1980. Manual of the Mammals of Sri Lanka. $2^{\text {nd }}$ ed. Wildlife and Nature Protection Society, Sri Lanka.

Werner, W. L. 1984. Die Höhen- und Nebelwälder auf der Insel Ceylon (Sri Lanka). Tropische und subtropische Pflanzenwelt 46. Steiner, Wiesbaden.

\section{Simakobu or Pig-Tailed Snub-Nose Langur, Pagai}

Simias concolor

Chasen, F. N. and C. B. Kloss. 1927. Spolia MentawiensiaMammals. Proc. Zool. Soc. Lond. 53: 797-840.

Fuentes, A. 1996/1997. Current status and future viability for the Mentawai primates. Primate Conserv. (17): $111-116$.

Fuentes, A. 2002. Monkeys, humans and politics in the Mentawai Islands: No simple solutions in a complex world. 
In: Primates Face to Face: Conservation Implications of Human-Nonhuman Primate Interactions, A. Fuentes and L. D. Wolfe (eds.), pp.187-207. Cambridge University Press, Cambridge.

Kobold, S., T. Ziegler and R. Maennel. 2003. The primates of Mentawai and the Siberut Conservation Project. ZGAP Mitteilungen 19: 7-9.

Miller, G. S. 1903. Seventy new Malayan mammals. Smithsonian Miscellaneous Collection (45): 1-73.

Mitchell, A. H. and R. L. Tilson. 1986. Restoring the balance: traditional hunting and primate conservation in the Mentawai Islands, Indonesia. In: Primate Ecology and Conservation, J. G. Else and P. C. Lee (eds.), pp.249-260. Cambridge University Press, Cambridge, UK.

Paciulli, L. M. 2004. The Effects of Logging, Hunting, and Vegetation on the Densities of the Pagai, Mentawai Island Primates. State University of New York at Stony Brook.

PHPA. 1995. Siberut National Park Integrated Conservation and Development Management Plan (1995-2020). Volume I: Current Conditions and Evaluation; Volume II: Action Plan for Conservation and Development; Volume III: Appendices. Chemonics International in association with PT. Indeco Duta Utama and PT. Nadya Karsa Amerta, for Ditjen Perlindungan Hutan dan Pelestarian Alam, Departemen Kehutanan, Republik Indonesia, Jakarta.

Tenaza, R. R. and A. Fuentes. 1995. Monandrous social organization of pigtailed langurs (Simias concolor) in the Pagai Islands, Indonesia. International Journal of Primatology 16: 29-310.

Ting, N., D. J. Whittaker and D. J. Melnick. 2005. The phylogenetic position of the simakobu monkey (Simias concolor) based on mitochondrial sequence data. Am. J. Phys. Anthropol. Suppl. 40: 206. (Abstract)

Waltert, M., C. Abegg, T. Ziegler, S. Hadi, D. Priata and K. Hodges, K. Submitted. Abundance and community structure of Mentawai primates in the Peleonan Forest, North Siberu.

Watanabe, K. 1981. Variations in group composition and population density of the two sympatric Mentawaian leafmonkeys. Primates 22: 145-160.

Whittaker, D. J. 2006. A conservation action plan for the Mentawai primates. Primate Conserv. (20): 95-105.

Yanuar, A., A. Fuentes and K. Studd. 1999. A short report on the current status of the Mentawai snub-nosed langur (Simias concolor concolor) on Simalegu Island, South Pagai, Mentawai, Indonesia. Trop. Biodiv. 5(3): 299-305.

\section{Delacour's Langur}

Trachypithecus delacouri

Nadler, T. 1996. Report on the distribution and status of Delacour's langur (Trachypithecus delacouri). Asian Primates 6: $1-4$.

Nadler, T. 2004. Distribution and status of the Delacour's langur (Trachypithecus delacouri) and recommendations for its long-term conservation. In: Conservation of Primates in Vietnam, T. Nadler, U. Streicher and Ha Thang Long (eds.), pp.63-71.Frankfurt Zoological Society, Hanoi.

Nadler, T., F. Momberg, Nguyen Xuan Dang and N. Lormee. 2003. Vietnam Primate Conservation Status Review 2002. Part 2: Leaf Monkeys. Fauna and Flora International and Frankfurt Zoological Society, Hanoi. pp. 145-164.

Ratajszczak, R., R. Cox and Ha Dinh Duc. 1990. A Preliminary Survey of Primates in North Vietnam. Report to World Wide Fund for Nature - WWF, Project 3869, Gland.

\section{Golden-headed Langur or Cat Ba Langur}

Trachypithecus poliocephalus poliocephalus

Groves, C. P. 2001. Primate Taxonomy. Smithsonian Institution Press, Washington, DC.

Nadler, T. and Ha Thang Long. 2000. The Cat Ba Langur: Past, Present and Future. The Definitive Report on Trachypithecus poliocephalus - the World's Rarest Primate. Frankfurt Zoological Society, Hanoi. 104pp.

Nadler, T., F. Momberg, Nguyen Xuan Dang and N. Lormee. 2003. Vietnam Primate Conservation Status Review 2002. Part 2: Leaf Monkeys, pp.55-67. Fauna and Flora International - Vietnam Program and Frankfurt Zoological Society, Hanoi.

Roos, C., T. Nadler, Y. P. Zhang and H. Zischler. 2001. Molecular evolution and distribution of the superspecies Trachypithecus [francoisi]. Folia Primatol. 72: 181-182.

Stenke, R. 2005. Conservation of the Golden-headed Langur (Trachypithecus poliocephalus poliocephalus) on Cat $\mathrm{Ba}$ Island, Vietnam. Status of the Golden-headed Langur and of Human Impact in Langur Areas. Report to the People's Committee of Hai Phong (Provincial Government). Cat Ba, Hai Phong (in Vietnamese).

Stenke, R. and Chu Xuan Canh. 2004. The golden-headed langur (Trachypithecus poliocephalus poliocephalus) on Cat Ba Island-status, threat factors, and recovery options. In: Conservation of Primates in Vietnam, T. Nadler, U. Streicher and Ha Thang Long (eds.), pp.72-77. Frankfurt Zoological Society, Hanoi.

\section{Western Purple-faced Langur}

Semnopithecus vetulus nestor

Dela, J. D. S. 1998. The ecology and social biology of a selected population of the western purple-faced leaf monkey (Trachypithecus vetulus nestor $=$ Presbytis senex nestor). $\mathrm{PhD}$ thesis, University of Peradeniya, Peradeniya.

Hill, W. C. O. 1934. A monograph on the purple-faced leaf monkeys (Pithecus vetulus). Ceylon J. Sci. (B) 19 (Pt.1): $23-88$.

Molur, S., Brandon-Jones, D., Dittus, W., Eudey, A., Kumar, A., Singh, M., Feeroz, M. M., Chalise, M., Priya, P. and Walker, S. (eds.). 2003. Status of South Asian Primates: Conservation Assessment and Management Plan (CAMP) Workshop Report, 2003. Zoo Outreach Organisation, IUCN/SCC Conservation Breeding Specialist Group South Asia, Coimbatore, India. viii + 432pp. 
Grey-shanked Douc

Pygathrix cinerea

Ha Thang Long. 2000. Records of grey-shanked douc langur (Pygathrix cinerea) in the Central Highlands of Vietnam. Report to Frankfurt Zoological Society, Hanoi.

Ha Thang Long. 2004. Distribution and status of the greyshanked douc langur (Pygathrix cinerea) in Vietnam. In: Conservation of Primates in Vietnam, T. Nadler, U. Streicher and Ha Thang Long (eds.), pp. 52-57. Frankfurt Zoological Society, Hanoi.

Lippold, L. K. and Vu Ngoc Thanh. 2000. The grey-shanked douc langur: Survey results from Tien Phuoc, Quang Nam, Vietnam. Asian Primates 7(1-2): 1-3.

Nadler, T. 1997. A new subspecies of Douc langur, Pygathrix nemaeus cinereus ssp.nov. Zool. Garten (NF) 67(4): $165-176$.

Nadler, T., Momberg, F., Nguyen Xuan Dang and Lormee, N. 2003. Vietnam Primate Conservation Status Review 2002. Part 2: Leaf Monkeys, pp.113-143. Fauna \& Flora International and Frankfurt Zoological Society, Hanoi.

Pham Nhat. 1993. The distribution and status of the douc langur (Pygathrix nemaeus) in Vietnam. Asian Primates 3(1-2): $2-3$.

Roos, C. and Nadler, T. 2001. Molecular evolution of the douc langurs. Zool. Garten (NF) 71: 1-6.

\section{Tonkin Snub-nosed Monkey}

Rhinopithecus avunculus

Boonratana, R. and Le Xuan Canh. 1998. Conservation of Tonkin snub-nosed monkeys (Rhinopithecus [Presbyticus] avunculus) in Vietnam. In: The Natural History of the Doucs and Snub-nosed Monkeys, N. G. Jablonsky (ed.), pp.207-215. World Scientific Publishing, Singapore.

Dong Thanh Hai, Do Quang Huy, Lu Quang Vinh, Nguyen Duc Manh, Nguyen Hai Ha, Ngo Duy Bach and Vu Duc Kham. 2006. A survey of distribution and population status of Tonkin snub-nosed monkey (Rhinopithecus avunculus) in Cham Chu Nature Reserve. Report, Forestry University of Vietnam, Department of Wildlife Manangement, Xuan Mai.

Le Khac Quyet. 2004. Distribution and conservation of the Tonkin snub-nosed monkey (Rhinopithecus avunculus) in Du Gia Nature Reserve, Ha Giang Province, northeast Vietnam. In: Conservation of Primates in Vietnam, T. Nadler, U. Streicher and Ha Thang Long (eds.), pp.58-62. Frankfurt Zoological Society, Hanoi.

Le Khac Quyet and S. P. Simmons. 2002. Results of surveys on Tonkin snub-nosed monkey (Rhinopithecus avunculus) in the Northeastern Vietnam. Report to Singapore Zoo and Fauna and Flora International, Hanoi.

Nadler, T., F. Momberg, Nguyen Xuan Dang and N. Lormee. 2003. Vietnam Primate Conservation Status Review 2002. Part 2: Leaf Monkeys, pp.145-164. Fauna and Flora International and Frankfurt Zoological Society, Hanoi.

\section{Hainan Gibbon}

Nomascus hainanus

Bleisch, W. V. and N. Chen. 1991. Ecology and behavior of wild black-crested gibbons in China with a reconsideration of evidence of polygyny. Primates 32: 539-548.

Chan, B. P. L., J. R. Fellowes, T. Geissmann and J. F. Zhang (eds.). 2005. Hainan Gibbon Status Survey and Conservation Action Plan - Version I (Last updated November 2005). Kadoorie Farm and Botanic Garden Technical Report No. 3. KFBG, Hong Kong SAR, iii + 33 pp. <www. gibbons.de/main/books/2005hainan-gibbon-status.pdf $>$.

Chan, B. P. L., X. F. Tan and W. J. Tan. In preparation. Rediscovery of the Critically Endangered Eastern Black Crested Gibbon Nomascus nasutus nasutus (Hylobatidae) in China; with preliminary notes on population size, ecology and conservation status.

Fan P. F., X. L. Jiang, C. M. Liu and W. S. Luo. 2006. Polygynous mating system and behavioural reason of Black Crested Gibbon (Nomascus concolor jingdongensis) at Dazhaizi, Mt. Wuliang, Yunnan, China. Zool. Res. 27(2): 216-220.

Fellowes, J. R. and B. Chan. 2004. Hainan Gibbon: concerted action for the world's most endangered ape. Living Forests 7: 22-24

Geissmann, T., Dang X. Nguyen, N. Lormée and F. Momberg. 2000. Vietnam Primate Conservation Status Review 2000.

Part 1: Gibbons. Fauna and Flora International, Indochina Programe, Hanoi.

Geissmann, T., Trung Q. La, Hoang D. Trinh, Thong D. Vu, Dang, N. Can and Pham, D. Tien. 2003. Rarest ape rediscovered in Vietnam. Asian Primates 8(3/4): 8-10.

Geissmann, T. 2003. Symposium on Gibbon Diversity and Conservation: Concluding resolution. Asian Primates 8(3/4): $28-29$.

Geissmann, T. and B. Chan. 2004. The Hainan black crested gibbon: Most critically endangered ape. Folia Primatol. 75 (Suppl. 1): 116. (Abstract.)

Hainan Daily Online, 2007a. Website: $<$ http://hnrb.hinews.cn/ php/20070326/162705.php>.

Hainan Daily Online, 2007b. Website: $<$ http://hnrb.hinews.cn/ php/20070326/162706.php>.

Kadoorie Farm \& Botanic Garden. 2001. Report of Rapid Biodiversity Assessments at Bawangling National Nature Reserve and Wangxia Limestone Forest, Western Hainan, 3 to 8 April 1998. South China Forest Biodiversity Report Series: No. 2. KFBG, Hong Kong SAR, ii + 33pp.

La Q. Trung and Hoang D. Trinh. 2004. Status review of the Cao Vit black crested gibbon (Nomascus nasutus nasutus) in Vietnam. In: Conservation of Primates in Vietnam, T. Nadler, U. Streicher, and Long T. Ha (eds.), pp.90-94. Frankfurt Zoological Society, Hanoi.

Liu, Z. H. and C. F. Tan. 1990. An analysis of habitat structure of the Hainan gibbon. Acta Theriologica Sinica 10: 163-169. In Chinese with English summary. 
Liu, Z. H., S. M. Yu and X. C. Yuan 1984. Resources of the Hainan black gibbon and its present situation. Chinese Wildlife 6: 1-4. In Chinese.

Liu, Z. H., Y. Z. Zhang, H. S. Jiang and C. H. Southwick. 1989. Population structure of Hylobates concolor in Bawanglin Nature Reserve, Hainan, China. Am. J. Primatol. 19: 247-254.

Mootnick, A. R. 2006. Gibbon (Hylobatidae) species identification recommended for rescue and breeding centers. Primate Conserv. (21): 103-138.

Nadler, T. 2003. Rediscovery of the Eastern black crested gibbon Nomascus nasutus in Vietnam. The Gibbon's Voice 6(1): $1-3$.

People's Daily Online, 2006. Website: $<$ http://english.people. com.cn/200611/15/print20061115 321610.html.>.

Roos, C. 2004. Molecular evolution and systematics of Vietnamese primates. In: Conservation of Primates in Vietnam, T. Nadler, U. Streicher and Ha Thang Long (eds.), pp.23-28. Frankfurt Zoological Society, Hanoi.

Roos, C. and T. Nadler 2005. Molecular evolution and systematics of Indochinese primates. Primate Rep. 72(1): $38-39$.

Roos, C., V. N. Thanh, L. Walter, and T. Nadler. 2007. Molecular systematics of Indochinese primates. Vietnamese $J$. Primatol. 1: 41-53.

VNA. 2004. Endangered gibbon and rare flora species found. Report on web site of Sci/Tech-Environment, Vietnam News Agency (VNA), Hanoi. <http://www.vnagency. com.vn>. Accessed: 17 November 2004.

Wang, S. and G. Quan. 1986. Primate status and conservation in China. In: Primates: The Road to Self-sustaining Populations, K. Benirschke (ed.), pp.213-220. Springer Verlag, New York.

Wu, W., X. M. Wang, F. Claro, Y. Z. Ding, A. C. Souris, C. D. Wang, C. H. Wang and R. Berzins. 2004. The current status of the Hainan black-crested gibbon Nomascus sp. cf. nasutus hainanus in Bawangling National Nature Reserve, Hainan, China. Oryx 38(4): 452-456.

Zhou, J., F. W. Wei, M. Li, J. F. Zhang, D. L. Wang and R. L. Pan. 2005. Hainan Black-crested Gibbon is headed for extinction. Int. J. Primatol. 26(2): 453-465.

\section{Western Hoolock Gibbon}

Hoolock hoolock

Choudhury, A. 2001. Primates in northeast India: An overview of their distribution and conservation. ENVIS Bulletin: Wildlife and Protected Areas 1(1): 92-101.

Das, J., M. M. Feeroz, M. A. Islam, J. Biswas, P. Bujarborua, D. Chetry, R. Medhi and J. Bose. 2003. Distribution of hoolock gibbon (Bunopithecus hoolock hoolock) in India and Bangladesh. Zoos' Print Journal 18(1): 969-976.

Das, J., J. Biswas, R. Medhi, J. Bose, D. Chetry, P. Bujorborua and F. Begum. 2003. Distributional status of hoolock gibbon (Bunopithecus hoolock) and their conservation in southern Assam, India. Tigerpaper 30(4): 26-29.
Das, J., P. C. Bhattacherjee, J. Biswas and D. Chetry. 2005. Western Hoolock Gibbon: Socioecology, Threats and Conservation Action Plan. Department of Zoology, Gauhati University, and Primate Research Centre, Northeast Centre, Guwahati, India. 70pp.

Das, J., J. Biswas, P. C. Bhattacharjee and S. M. Mohnot, S.M. 2006. First distribution records of the eastern hoolock gibbon (Hoolock hoolock leuconedys) from India. Zoos ' Print Journal 21(7): 2316-2320.

Islam, A. and M. M. Feeroz. 1992. Ecology of the hoolock gibbon of Bangladesh. Primates 33(4): 451-464.

Kakati, K. 2006. Fragment-living - a study of hoolock gibbons in Assam, India. Gibbon's Voice 8(1): 1-4.

Kakati, K. and S. Sathyakumar. 1999. The effect of habitat loss on feeding and ranging behavior of hoolock gibbons (Hylobates hoolock) in a small forest fragment in north east India. In: Fourth International Anthropological Congress of Ales Hrdlicka: Abstracts, D. Sabik, J. Vigner and M. Vigner (eds.), p.73. World Anthropology at the turn of the Century, Set Out, Prague.

MacKinnon, J. and K. MacKinnon. 1987. Conservation status of the primates of the Indo-Chinese subregion. Primate Conserv. (8): 187-195.

Molur, S., D. Brandon-Jones, W. Dittus, A. Eudey, A. Kumar, M. Singh, M. M. Feeroz, M. Chalise, P. Priya and S. Walker. 2003. Status of South Asian Primates: Conservation Assessment and Management Plan (C.A.M.P.) Workshop Report, 2003. Zoo Outreach Organisation/CBSGSouth Asia, Coimbatore, India. 432pp.

Molur, S., S. Walker, A. Islam, P. Miller, C. Srinivasulu, P. O. Nameer, B. A. Daniel and L. Ravikumar, L. (eds.). 2005. Conservation of Western Hoolock Gibbon (Hoolock hoolock hoolock) in India and Bangladesh: Population and Habitat Viability Assessment (P.H.V.A.) Workshop Report, 2005. Zoo Outreach Organisation/CBSG South Asia, Coimbatore, India. 132pp.

Mootnick, A. R. 2006. Gibbon (Hylobatidae) species identification recommended for rescue or breeding centers. Primate Conserv. (21): 103-138.

Mootnick, A. R. and C. P. Groves. 2005. A new generic name for the hoolock gibbon (Hylobatidae). Int. J. Primatol. 26: $971-976$.

\section{Sumatran Orangutan}

Pongo abelii

Ellis, S., Singleton, I., Andayani, N., Traylor-Holzer, K. and Supriatna, J. (eds.). 2006. Sumatran Orangutan Conservation Action Plan. Conservation International, Jakarta, Indonesia, and Washington, DC.

IUCN. 2004. 2004 IUCN Red List of Threatened Species. IUCN: The World Conservation Union, Gland.

Rao, M. and van Schaik, C.P. 1997. The Behavioural ecology of Sumatran orangutans in logged and unlogged Forest. Trop. Biodiv. 4(2): 173-185.

Rijksen, H. D. 2001. The orangutan and the conservation battle in Indonesia. In: Great Apes and Humans: The Ethics 
of Co-existence, B. B. Beck, T. S. Stoinski, M. Hutchins, T. L. Maple, B. Norton, A. Rowan, E. F. Stevens and A. Arluke (eds.), pp.57-70. Smithsonian Institution Press, Washington, DC.

Rijksen, H. D. and E. Meijaard. 1999. Our Vanishing Relative: The Status of Wild Orangutans at The Close of The Twentieth Century. Kluwer Academic Publishers, Dordrecht.

Singleton, I., S. Wich, S. Husson, S. Stephens, S. Utami Atmoko, M. Leighton, N. Rosen, K. Traylor-Holzer, R. Lacy and O. Byers (eds.). 2004. Orangutan Population and Habitat Viability Assessment: Final Report. IUCN/ SSC Conservation Breeding Specialist Group (CSG), Apple Valley, MN.

Van Schaik, C. P., K. A. Monk and J. M. Y. Robertson. 2001. Dramatic decline in orangutan numbers in the Leuser Ecosystem, northern Sumatra. Oryx 35(1): 14-25.

Wich, S. A. and M. L. Geurts. 2001. Orangutan Surveys in Sumatra Utara, Riau and Sumatra Barat. Survey Report to the Golden Ark Foundation, The Netherlands.

\section{Brown Spider Monkey}

Ateles hybridus

Cordero-Rodriguez, G. A. and F. Biord. 2001. Distribution and conservation of the spider monkey (Ateles hybridus) in the coastal range of northern Venezuela. Neotrop. Primates 9: 8-11.

Defler, T. R. 2003. Primates de Colombia. Conservación Internacional, Serie de Guías Tropicales de Campo, Conservación Internacional Colombia, Bogota, Colombia.

Kellogg, R. and E. A. Goldman. 1944. Review of the spider monkeys. Proc. U. S. Natl. Mus. 96: 1-45.

Konstant, W. R., R. A. Mittermeier and S. D. Nash. 1985. Spider monkeys in captivity and in the wild. Primate Conserv. (5): 82-109.

Mondolfi, E. and J. F. Eisenberg. 1979. New records for Ateles belzebuth hybridus in northern Venezuela. In: Vertebrate Ecology in the Northern Neotropics, J. F. Eisenberg (ed.), pp.93-96. Smithsonian Institution Press, Washington, DC.

Morales-Jiménez, A. L. 2004. Modeling distributions for Colombian spider monkeys (Ateles sp.) using GARP and GIS to find priority areas for conservation. Master's thesis, Social Sciences and Law, Oxford Brookes University, Oxford, UK.

\section{Brown-Headed Spider Monkey}

Ateles fusciceps fusciceps

Albuja, L. 1983. Mamíferos ecuatorianos considerados raros o en peligro de extinción. In: Programa Nacional Forestal, pp.35-67. Ministerio de Agricultura y Ganadería, Quito.

Albuja, L. 1991. Lista de vertebrados del Ecuador: Mamíferos. Rev. Politécnica 16(3):163-203.

Albuja, L., M. Ibarra, J. Urgilés and R. Barriga. 1980. Estudio preliminar de los vertebrados ecuatorianos. Report,
Departamento de Ciencias Biológicas, Escuela Politécnica Nacional, Quito. 143pp.

Albuja, L. and P. Mena-Valenzuela. 1990. Mamíferos del noroccidente de Ecuador. Report, Departamento de Ciencias Biológicas, Escuela Politécnica Nacional, Quito. $148 p p$.

Baker, R. H. 1974. Records of mammals from Ecuador. Michigan State Univ. Mus. Publ., Biol. Ser. 5(2): 131-146.

Eisenberg, J. F. 1976. Communication mechanisms and social integration in the black spider monkey, Ateles fusciceps and A. geoffroyi. J. Mammal. 54: 955-957.

Eisenberg, J. F. and K. H. Redford. 1999. Mammals of the Neotropics. Vol. 3. The Central Neotropics: Ecuador, Peru, Bolivia, Brazil. The University of Chicago Press, Chicago.

Emmons, L. H. and L. Albuja. 1992. Mammal fauna. In: Status of Forest Remnants in the Cordillera de la Costa and Adjacent Areas of Southwestern Ecuador. Rapid Assessment Program (RAP). Working Papers 2, T. A. Parker, III and J. L. Carr (eds.), pp.60-62. Conservation International, Washington, DC.

Emmons, L. H. and F. Feer. 1999. Mamíferos de los Bosques Húmedos de América Tropical, una Guía de Campo. Editorial FAN, Santa Cruz de la Sierra, Bolivia.

Gavilanez-Endara, M. M. 2006. Demografía, actividad y preferencia de hábitat de tres especies de primates (Alouatta palliata, Ateles fusciceps y Cebus capucinus) en un bosque nublado del noroccidente ecuatoriano. Tesis de licenciatura, Pontificia Universidad Católica del Ecuador, Quito.

Groves, C. P. 2001. Primate Taxonomy. Smithsonian Institution Press, Washington, DC.

Hilton-Taylor, C. 2000. 2000 IUCN Red List of Threatened Species. The World Conservation Union (IUCN), Gland, Switzerland, and Cambridge, UK.

Kellogg, R. and E. A. Goldman. 1944. Review of the spider monkeys. Proc. U. S. Natl. Mus. 96(3186): 1-45.

Madden, R. H. and L. Albuja. 1986. The conservation status of Ateles fusciceps fusciceps in the Reserva Ecológica Cotacachi-Cayapas, northwestern Pacific lowlands, Ecuador, South America. Report, Duke University, Durham and Escuela Politécnica Nacional, Quito. 86pp.

Madden, R. H. and L. Albuja. 1989. Estado actual de Ateles fusciceps fusciceps en el noroccidente ecuatoriano. Rev. Politécnica 14(3): 113-157.

Mena-Valenzuela, P. and A. Ruiz. 1997. Diversidad y abundancia relativa de los mamíferos de río Negro (Lita, El Cristal), zona de amortiguamiento de la Reserva Ecológica Cotacachi-Cayapas, Esmeraldas, Ecuador. In: Estudios Biológicos para la Conservación: Diversidad, Ecología y Etnobiología, P. A. Mena, A. Soldi, R. Alarcón, C. Chiriboga and L. Suárez (eds.), pp.181-194. EcoCiencia. Quito.

Ministerio del Ambiente. 2000. Regúlase el Control de Cacería y Vedas de Especies de Fauna silvestre en el Territo- 
rio Nacional. Registro Oficial No. 5 del 28 de enero del 2000, Ministerio del Ambiente, Quito.

Ministerio del Ambiente. 2002. Reconocer como los Libros Rojos Oficiales de Especies Amenazadas del Ecuador. Registro Oficial No. 50 del 8 de octubre del 2002, Ministerio del Ambiente, Quito.

Rowe, N. 1996. The Pictorial Guide to the Living Primates. Pogonias Press, East Hampton, NY.

Sierra, R. 1996. La Deforestación en el Noroccidente del Ecuador 1983-1993. EcoCiencia, Quito.

Suárez, L. and M. García. 1986. Extinción de Animales en el Ecuador, Descripción de 60 Especies Amenazadas. Fundación Natura, Quito.

Tirira, D. 1999a. Mamíferos del Ecuador. Museo de Zoología, Pontificia Universidad Católica del Ecuador y SIMBIOE, Publicación Especial sobre los mamíferos del Ecuador 1. Quito.

Tirira, D. 2000. Listado Bibliográfico Sobre los Mamíferos del Ecuador. Boletines Bibliográficos Sobre la Biodiversidad del Ecuador No. 2. Publicación Especial sobre los Mamíferos del Ecuador 3, EcoCiencia and SIMBIOE, Quito.

Tirira, D. 2001a. Mono araña de cabeza café (Ateles fusciceps). In: Libro Rojo de los Mamíferos del Ecuador, D. Tirira (ed.), pp.105-106. Serie Libros Rojos del Ecuador 1. Publicación Especial sobre los Mamíferos del Ecuador 4, SIMBIOE, EcoCiencia, Ministerio del Ambiente y UICN, Quito.

Tirira, D. 2001b. Libro Rojo de los Mamíferos del Ecuador. Serie Libros Rojos del Ecuador 1. Publicación Especial sobre los mamíferos del Ecuador 4, SIMBIOE, EcoCiencia, Ministerio del Ambiente y UICN, Quito.

Tirira, D. 2003. Estado actual del mono araña de cabeza café (Ateles fusciceps) (Primates: Cebidae) en el Ecuador. Website: <http://spidermonkey.zoodoue.fr/Estudio-Ateles-fusciceps.htm>, Accessed 3 January 2007.

Tirira, D. 2004. Estado actual del mono araña de cabeza café (Ateles fusciceps Gray, 1866) (Primates: Atelidae) en el Ecuador. Lyonia 6(2): 17-24.

Tirira, D. 2007. Guía de Campo de los Mamíferos del Ecuador. Publicación Especial sobre los Mamíferos del Ecuador 6. Ediciones Murciélago Blanco, Quito. 576pp.

\section{Peruvian Yellow-tailed Woolly Monkey}

Oreonax flavicauda

Aquino, R. and F. Encarnación. 1994. Primates of Peru-Los Primates del Perú. Primate Rep. 40: 1-127.

Butchart, S. H. M., R. Barnes, C. W. N. Davies, M. Fernandez and N. Seddon. 1995. Observations of two threatened primate species in the Peruvian Andes. Primate Conserv. 16: $15-19$.

DeLuycker, A. M. 2007. Notes on the yellow-tailed woolly monkey (Oreonax flavicauda) and its status in the Protected Forest of Alto Mayo, northern Peru. Primate Conserv. (22). In press. Website: < http://www.primate-sg. org/pc.htm>.
Graves, G. R. and J. P. O’Neill. 1980. Notes on the yellowtailed woolly monkey (Lagothrix flavicauda) of Peru. $J$. Mammal. 61: 345-347.

Leo Luna, M. 1980. First field study of the yellow-tailed woolly monkey. Oryx 15: 386-389.

Leo Luna, M. 1982. Estudio preliminar sobre la biología y ecológica del mono choro de cola amarilla Lagothrix flavicauda (Humboldt, 1812). Tesis, Universidad Nacional Agraria La Molina, Lima.

Leo Luna, M. 1984. The effect of hunting, selective logging, and clear-cutting on the conservation of the yellow-tailed woolly monkey (Lagothrix flavicauda). Master's thesis. University of Florida, Gainesville.

Leo Luna, M. 1987. Primate conservation in Peru: a case study of the yellow-tailed woolly monkey. Primate Conservation (8): 122-123.

Groves, C. 2001. Primate Taxonomy. Smithsonian Institution Press, Washington, DC.

Mittermeier, R. A., H. de Macedo Ruiz and A. Luscombe. 1975. A woolly monkey rediscovered in Peru. Oryx 13: 41-46.

Paredes Esquivel, Ú. M. [online] 2003. Relaciones filogenéticas dentro del género Lagothrix "mono choro" (Primates: Atelidae). Tesis para optar el título profesional de Biólogo con Mención en Zoología. Universidad Nacional Mayor de San Marcos, Lima, Perú. http://www.cybertesis.edu.pe/sisbib/2003/paredes_eu/ html/index-frames.html [last checked: 27 February 2007].

Parker, T. A. and L. J. Barkley. 1981. New locality for the yellow-tailed woolly monkey. Oryx 16: 71-72.

ParksWatch, Peru, 2007. Alto Mayo Protected Forest. Website: $<$ http://www.parkswatch.org/parkprofile.php?l=eng\&co untry $=$ per\&park $=$ ampf\&page $=$ thr $>$ Accessed: 5 March, 2007.

\section{Authors' addresses}

Aguiar, John M. Center for Applied Biodiversity Science, Conservation International, 2011 Crystal Drive, Suite 500, Arlington, VA 22202, USA, e-mail: <j.aguiar@conservation. org $>$.

Bearder, Simon K. Nocturnal Primate Research Group, Department of Anthropology, School of Social Science and Law, Oxford Brookes University, Oxford OX3 0BP, UK, e-mail: <skbearder@brookes.ac.uk>.

Brockelman, Warren Y. Center for Conservation Biology, Institute of Science and Technology for Research and Development, Mahidol University, Salaya, Phuttthamonthon 4 Road, Nakhon Pathom 73170, Thailand, e-mail: <wybrock@, cscoms.com>.

Butynski, Thomas M. Senior Conservation Biologist, Bioko Biodiversity Protection Program, Arcadia University, P. O. Box 149, 10400 Nanyuki, Kenya, e-mail: <TButynski@aol. com>.

Chan, Pui Lok Bosco. Species Protection Coordinator, China Programme, Kadoorie Farm \& Botanic Garden, Lam Kam 
Rd, Tai Po, New Territories, Hong Kong SAR, China, email: $<$ boscokf@kfbg.org $>$.

Craul, Mathias. Institute of Zoology, University of Veterinary Medicine Hannover, Bünteweg 17, 30559 Hannover, Germany, e-mail: <mathias.craul@tiho-hannover.de>.

Davenport, Tim R. B. Country Director, Tanzania Programme, Wildlife Conservation Society, P. O. Box 1475, Mbeya, Tanzania, e-mail:<tdavenport@wcs.org>.

Dela, Jinie. 45/1 Gunatilleke Mawatha, Etambogada, Panadua, Sri Lanka, e-mail: <jini@sltnet.lk>.

DeLuycker, Anneke M. Department of Anthropology, Washington University, St. Louis, Missouri, 63130, U.S.A., e-mail: $<$ amdeluyc@artsci.wustl.edu>.

Ehardt, Carolyn L. Department of Anthropology, University of Texas at San Antonio, San Antonio, TX 78249, USA, e-mail: <Carolyn.Ehardt@utsa.edu>.

Ellis, Susie. Executive Director, International Rhino Foundation, c/o 138 Strasburg Reservoir Road, Strasburg, VA 22657, USA, e-mail: <sellis@shentel.net>.

Fellowes, John R. China Programme, Kadoorie Farm \& Botanic Garden, Lam Kam Rd, Tai Po, New Territories, Hong Kong SAR, China, e-mail: <jrfellowes@yahoo.com>.

Ganzhorn, Jörg U. Institute of Zoology, Ecology and Conservation, Martin Luther King Platz 3, 20146 Hamburg, Germany, e-mail: <ganzhorn@zoologie.uni-hamburg.de>.

Heymann, Eckhard W. Abteilung Verhaltensforschung \& Ökologie, Deutsches Primatenzentrum, Kellnerweg 4, D-37077 Göttingen, Germany, e-mail: <eheyman@gwdg.de>.

Honess, Paul E. Department of Veterinary Services, University of Oxford, Parks Road, Oxford OX1 3PT, UK, e-mail: <paul.honess@vet.ox.ac.uk>.

Johnson, Steig. Department of Anthropology, 2500 University Drive, University of Calgary, Calgary, Canada AB T2N 1N4, e-mail: <steig.johnson@ucalgary.ca>.

Ha Thang Long. Frankfurt Zoological Society, Endangered Primate Rescue Center, Cuc Phuong National Park, Nho Quan District, Ninh Binh Province, Vietnam, e-mail: <thg_long@ yahoo.com>.

Hawkins, Frank. Africa Program, Conservation International, 2011 Crystal Drive, Suite 500, Arlington, VA 22202, USA, e-mail: <f.hawkins@conservation.org>.

Kierulff, M. Cecilia M. Fundação Parque Zoológico de São Paulo, Av. Miguel Stefano 4241, Água Funda, São Paulo 04301-905, São Paulo, Brazil, e-mail: <kierulff@uol.com.br>. Konstant, William R. 403 Poplar Road, Flourtown, Pennsylvania 19031, USA, e-mail: <bkonstant@houstonzoo.org>. Leighton, Mark. Harvard University, Peabody Museum, 11 Divinity Avenue, Cambridge, MA 02138, USA, e-mail: $<$ leighton@fas.harvard.edu>.

Le Khac Quyet. Fauna and Flora International - Vietnam Programme, IPO Box 78, 55 To Hien Thanh, Hanoi, Vietnam, e-mail: <quyet.khac.le@fff.rg.vn>.

Long, Yongcheng. The Nature Conservancy, China Program, 8th floor, Building of theYunnan Provincial Meteorological Bureau, 77 Xichang Rd, Kunming Yunnan 650034, China, e-mail: <ylong@tnc.org.cn>.
Mbora, David. Department of Biological Sciences, Dartmouth College, Hanover, NH 03755, USA, e-mail: $<$ David.N.M.Mbora@dartmouth.edu $>$.

McGraw, W. Scott. Department of Anthropology, The Ohio State University, 124 West 17th Avenue, Columbus, Ohio 43210-1364, USA, e-mail: <mcgraw.43@osu.edu>.

Meyers, David M. Wildlife Conservation Society, BP 8500, Antananarivo 101, Madagascar, e-mail: <meyersconsult@ yahoo.com>.

Mittermeier, Russell A. Conservation International, 2011 Crystal Drive, Suite 500, Arlington, VA 22202, USA, e-mail: $<$ r.mittermeier@conservation.org>.

Moisson, Pierre. Directeur, Parc Zoologique et Botanique, 51 rue du jardin zoologique, 68100 Mulhouse, France, e-mail: <pierre.moisson@agglo-mulhouse.fr>.

Molur, Sanjay. Wildlife Information Liaison Development 29-1, Bharathi Colony, Peelamedu, Coimbatore, Tamil Nadu 641004, India, e-mail: <herpinvert@gmail.com>.

Mootnick, Alan R. Director, Gibbon Conservation Center, P.O. Box 800249, Santa Clarita, CA 91380-0249 USA, e-mail: <gibboncenter@earthlink.net>.

Morales-Jiménez, Alba Lucia. Fundación BioDiversa, Colombia and New York Consortium in Evolutionary Primatology (NYCEP), Department of Anthropology, New York University, New York, NY 10003, USA, e-mail: <albalucia@, fundacionbiodiversa.org $>$.

Morgan, Bethan. Principal Investigator, Conservation and Research for Endangered Species (CRES), Zoological Society of San Diego, BP 3055 Messa, Yaoundé, Cameroon, e-mail: $<$ BMorgan@SanDiegoZoo.org>.

Nadler, Tilo. Frankfurt Zoological Society, Endangered Primate Rescue Center, Cuc Phuong National Park, Nho Quan District, Ninh Binh Province, Vietnam, e-mail: <t.nadler@, mail.hut.edu.vn>.

Nekaris, K. Anna I. Nocturnal Primate Research Group, Department of Anthropology, School of Social Science and Law, Oxford Brookes University, Oxford OX3 0BP, UK, e-mail: <anekaris@brookes.ac.uk>.

Oates, John F. Department of Anthropology, Hunter College, City University of New York (CUNY), 695 Park Avenue, New York, NY 10021, USA, e-mail: <john.oates@ hunter.cuny.edu>.

Olivieri, Gillian L. Institute of Zoology, University of Veterinary Medicine Hannover, Bünteweg 17, 30559 Hannover, Germany, e-mail: <gillian.olivieri@tiho-hannover.de>.

Paciulli, Lisa M. Department of Anthropology, 117 Gannett Center, Ithaca College, Ithaca 14850, NY, USA, e-mail: $<$ lpaciulli@ithaca.edu>.

Palacios, Erwin. Conservation International Colombia, Carrera 13 \# 71-41, Bogotá DC, Colombia, e-mail: <epalacios@ conservation.org $>$.

Patel, Erik R. Behavioral and Evolutionary Neuroscience Division, Department of Psychology, Cornell University, Ithaca, NY 14853, USA, e-mail: <erp8@cornell.edu>. 
Perkin, Andrew. C/o Tanzania Forest Conservation Group (TFCG), P.O. Box 23410, Dar es Salaam, Tanzania, e-mail: $<$ bwanakomba@yahoo.co.uk>.

Phan Duy Thuc. 'Cat Ba Langur Conservation Project', Cat Ba National Park; Cat Hai, Hai Phong, Vietnam, e-mail: $<$ pduythuc@yahoo.com>.

Randriatahina, Guy H. Département de Biologie Animale, Faculté des Sciences, Université d'Antananarivo, Madagascar, e-mail: <sahamalaza@aeecl.org>.

Ratsimbazafy, Jonah. Durrell Wildlife Conservation Trust - Madagascar Programme, B.P. 8511, 101 Antananarivo, Madagascar, e-mail: <jonah.ratsimbazafy@durrell.org>.

Rodríguez-Luna, Ernesto. Instituto de Neuroetología, Universidad Veracruzana, Apartado Postal 566, Xalapa, 91000 Veracruz, México, e-mail: <errodriguez@uv.mx>.

Roos, Christian. Gene Bank of Primates, Primate Genetics, German Primate Center, Kellnerweg 4, 37077 Goettingen, Germany, e-mail: <croos@dpz.gwdg.de>.

Rowe, Noel. Primate Conservation, Inc., 1411 Shannock Road, Charlestown, RI 02813-3726, USA, e-mail: <nrowe@ primate.org>.

Rylands, Anthony B. Center for Applied Biodiversity Science, Conservation International, 2011 Crystal Drive, Suite 500, Arlington, VA 22202, USA, e-mail: <a.rylands@conservation.org $>$.

Salim, Agus. The Nature Conservancy in Indonesia, Ecoregional and GIS Manager, Jalan Wijaya XIII No.9, Jakarta 12160, Indonesia. Current address: Jl. Palem Putri VIII No.5-7, Taman Yasmin V, Bogor 16113, Indonesia, e-mail: <asalim@cbn.net.id>.

Schwitzer, Christoph. Bristol Zoo Gardens, Clifton, Bristol BS8 3HA, UK, e-mail: <cschwitzer@bristolzoo.org.uk>, and Association Européenne pour l'Etude et la Conservation des Lémuriens (AEECL), Mulhouse, France, e-mail: <pd@aeecl. org $>$.

Schwitzer, Nora. WG Primatology, Zoologischer Garten Koeln, Cologne, Germany, e-mail: <nora.schwitzer@hotmail. de>.

Shekelle, Myron. Center for Biodiversity and Conservation Studies, Faculty of Mathematics and Science, University of Indonesia, Depok 16424, Indonesia. Current address: Department of Biological Sciences, National University of Singapore, 14 Science Drive 4, Singapore 117543, e-mails: <dbssm@nus.edu.sg>, <shekelle@tarsier.org>.

Singleton, Ian. Sumatran Orangutan Conservation Programme, P.O. Box 1472, Medan 20000, North Sumatra, Indonesia, e-mail: <mokko@indo.net.id>.

Stenke, Roswitha. 'Cat Ba Langur Conservation Project', Cat Ba National Park; Cat Hai, Hai Phong, Vietnam, e-mail: $<$ Rosi.Stenke@fpt.vn>.

Sunderland-Groves, Jacqui L. Wildlife Conservation Society, Cross River Gorilla Project, c/o Limbe Botanic Garden, P.O. Box 437, Limbe, South West Province, Cameroon, e-mail: <Takamanda@aol.com>.
Supriatna, Jatna. Conservation International Indonesia, J1. Pejaten Barat 16A, Kemang, Jakarta 12550, Indonesia, e-mail: $<j$.supriatna@conservation.org $>$.

Tirira, Diego. Museo Ecuatoriano de Ciencias Naturales. Murciélago Blanco, Apdo. 17-17-761, Quito, Ecuador, e-mail: $<$ diego_tirira@yahoo.com>.

Walker, Sally. Zoo Outreach Organisation, Post Box 1063, 29-1, Bharathi Colony, Peelamedu, Coimbatore, Tamil Nadu 641004, India, e-mail: <sallyrwalker@aol.com>.

Wang, Xiaoming. Shanghai Key Laboratory of Urbanization and Ecological Restoration, East China Normal University, 3663 Zhongshan Rd, Shanghai 200062 China, e-mail: $<$ xmwang@ecnu.edu.cn>.

Williamson, Liz. Department of Psychology, University of Stirling, Stirling FK9 4LA, Scotland. UK, E-mail: <e.a.williamson@stir.ac.uk>, <sga_coordinator@ conservation.org $>$.

Received for publication: May 2007

Revised: June 2007 


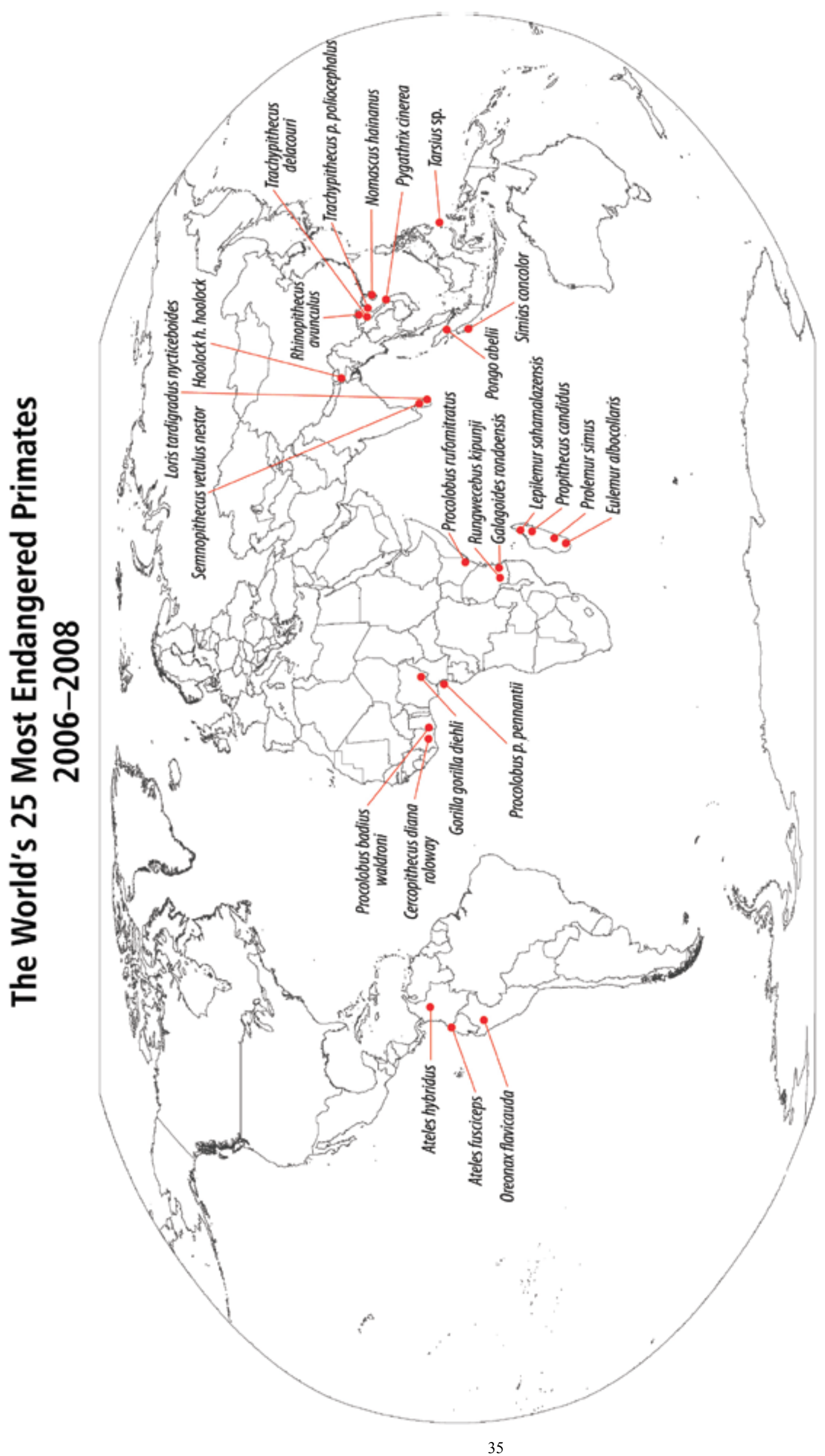




\section{Madagascar}

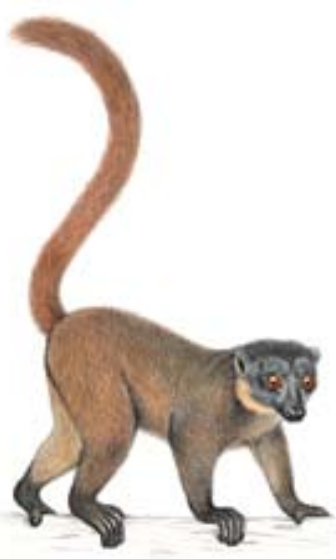

Greater Bamboo Lemur Prolemur simus

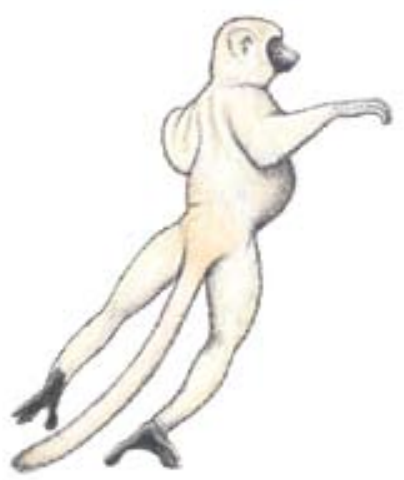

Silky Sifaka

Propithecus candidus
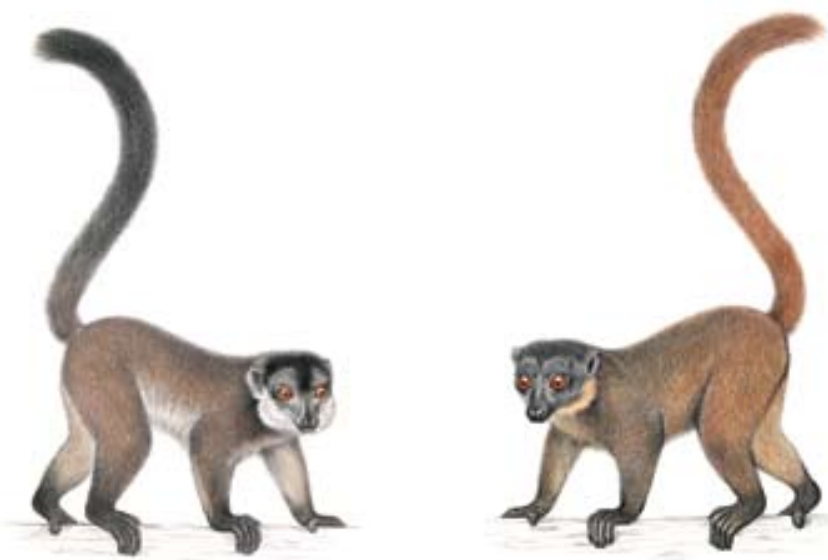

White-collared Lemur Male (left), Female (right)

Eulemur albocollaris

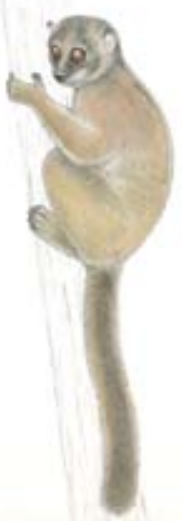

Sahamalaza Peninsula Sportive Lemur Lepilemur sahamalazensis

\section{Africa}

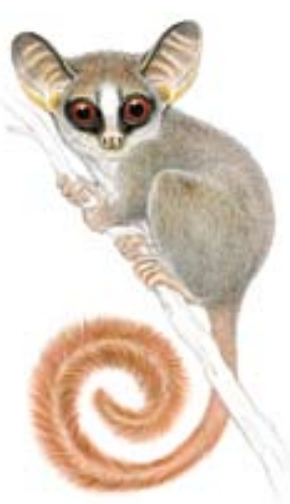

Rondo Dwarf Galago

Galagoides rondoensis

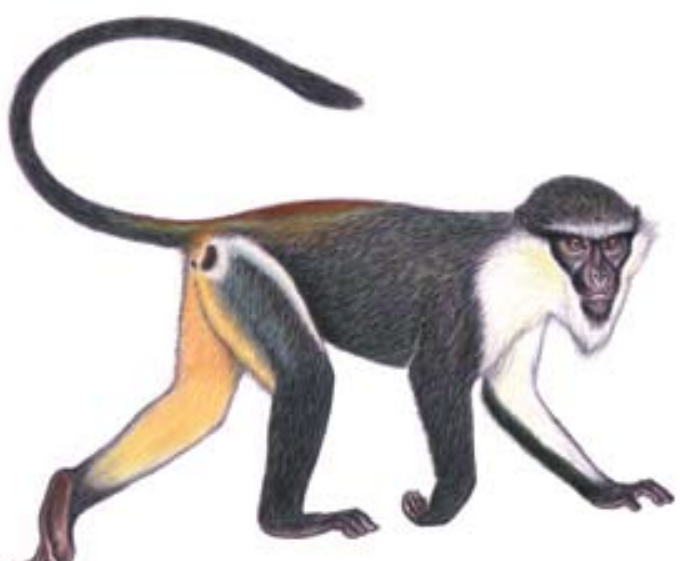

Roloway Monkey

Cercopithecus diana roloway 


\section{Africa, continued}

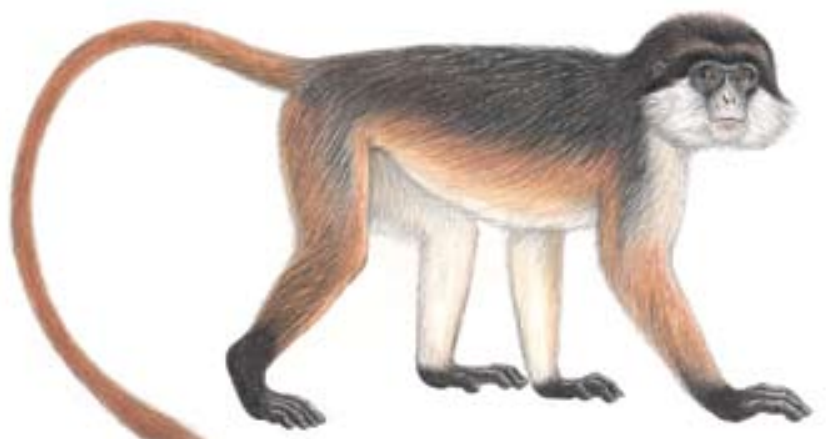

Pennant's Red Colobus

Procolobus p. pennantii

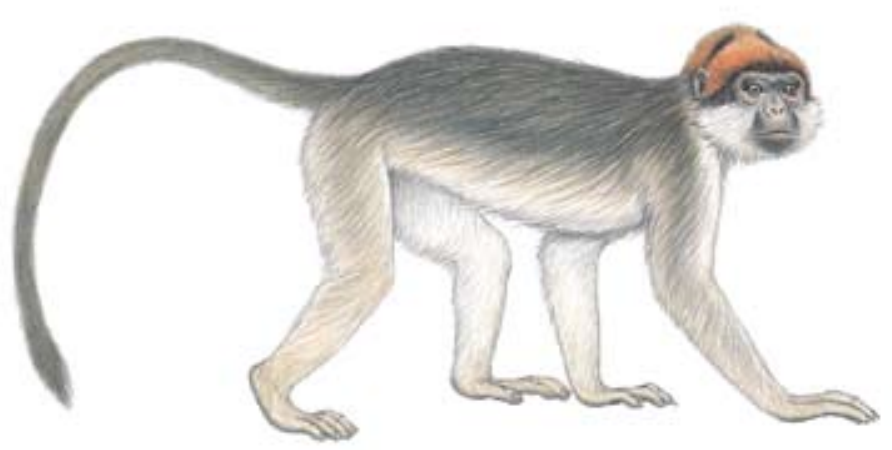

Tana River Red Colobus

Procolobus rufomitratus

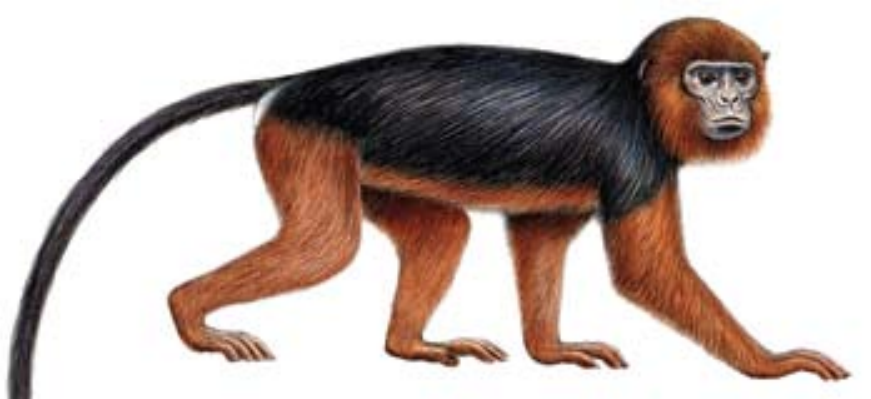

Miss Waldron's Red Colobus

Procolobus badius waldroni

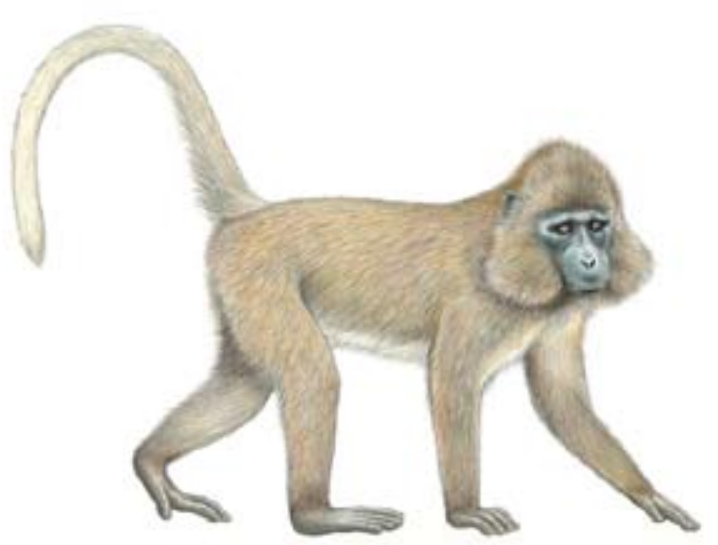

Kipunji or Highland Mangabey Rungwecebus kipunji

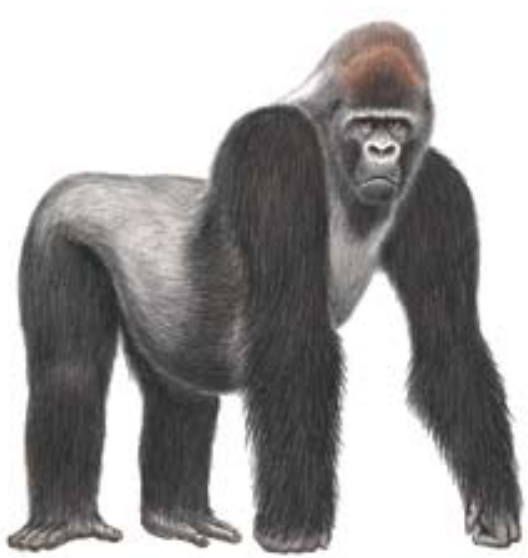

Cross River Gorilla

Gorilla gorilla diehli 


\section{Neotropical Region}

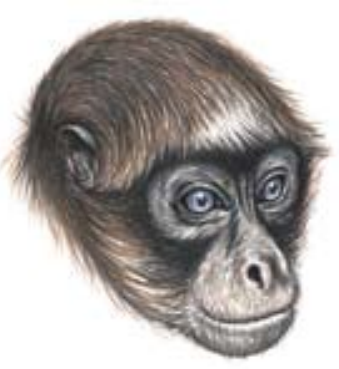

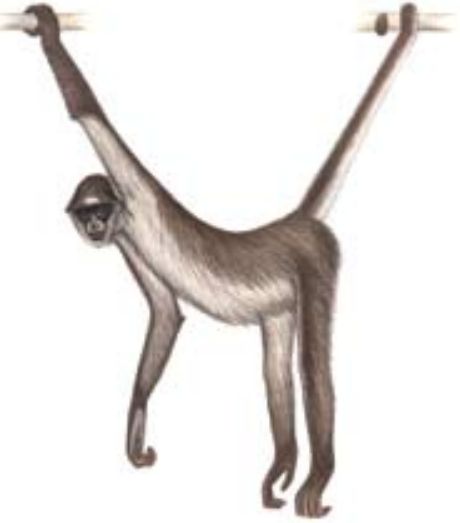

Variegated Spider Monkey

Ateles hybridus
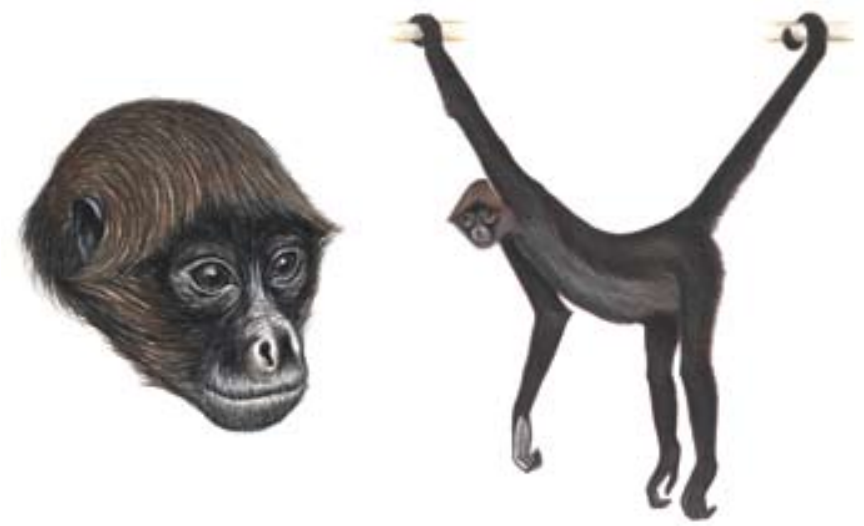

Brown-headed Spider Monkey

Ateles fusciceps

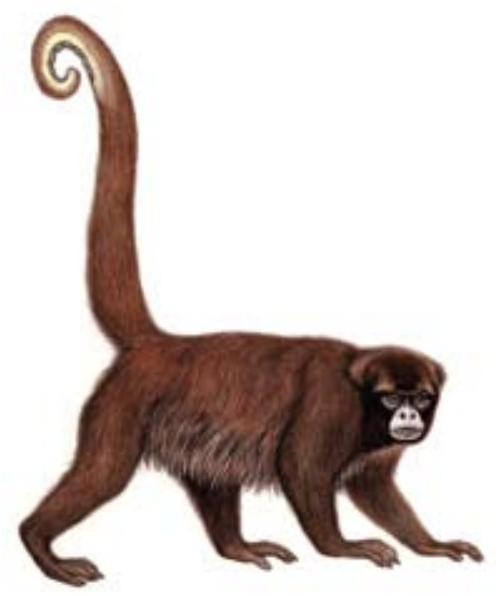

Peruvian Yellow-tailed Woolly Monkey

Oreonax flavicauda

\section{Asia}

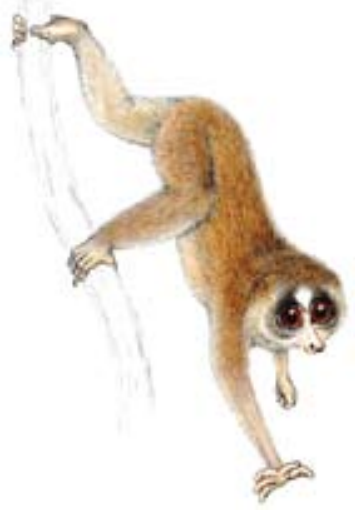

Horton Plains Slender Loris, Ceylon Mountain Slender Loris Loris tardigradus nycticeboides

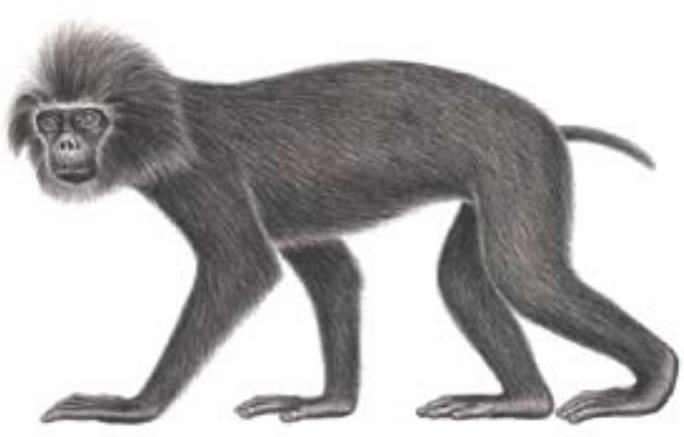

Pagai Pig-tailed Snub-nosed Monkey or Simakobu Simias concolor 


\section{Asia, continued}

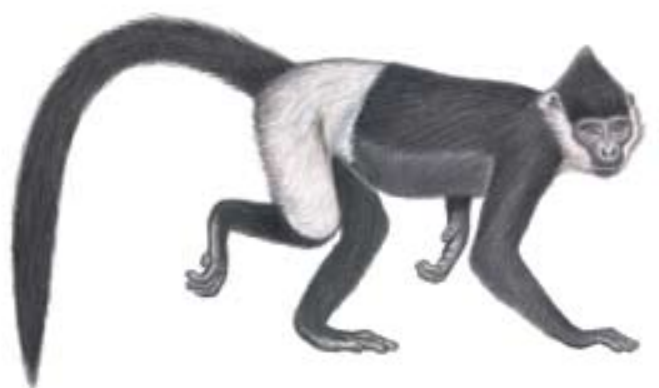

Delacour's Langur

Trachypithecus delacouri

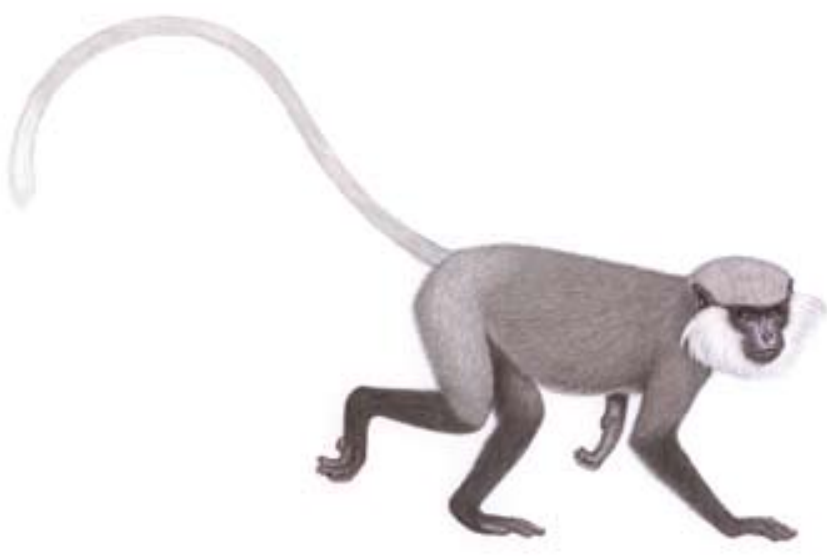

Western Purple-faced Langur

Semnopithecus vetulus nestor

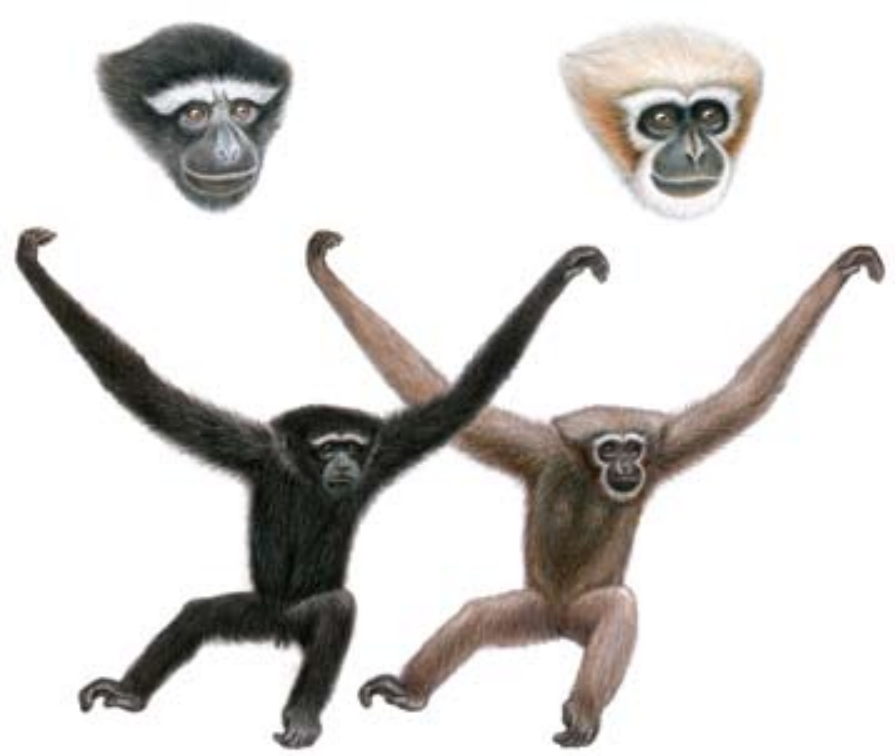

Western Hoolock Gibbon

Hoolock hoolock

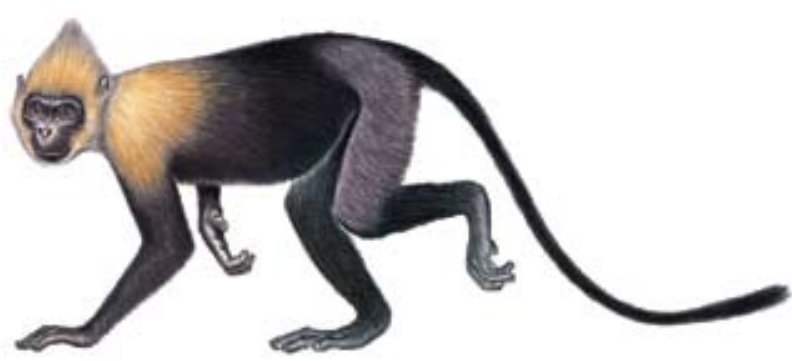

Golden-headed Langur or Cat Ba Langur

Trachypithecus poliocephalus poliocephalus

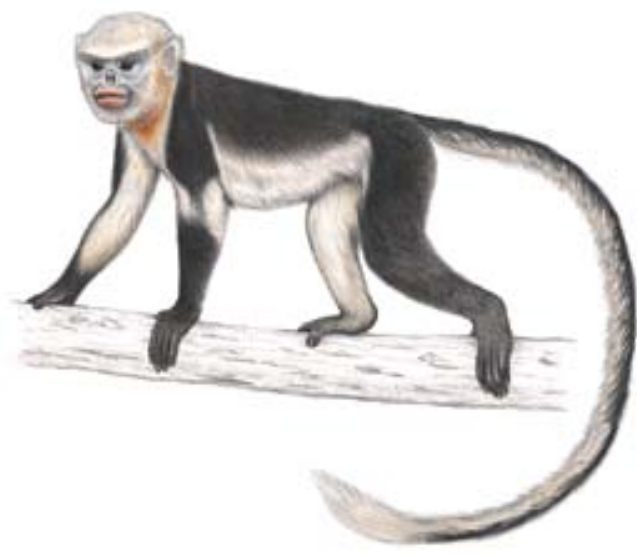

Tonkin Snub-nosed Monkey

Rhinopithecus avunculus

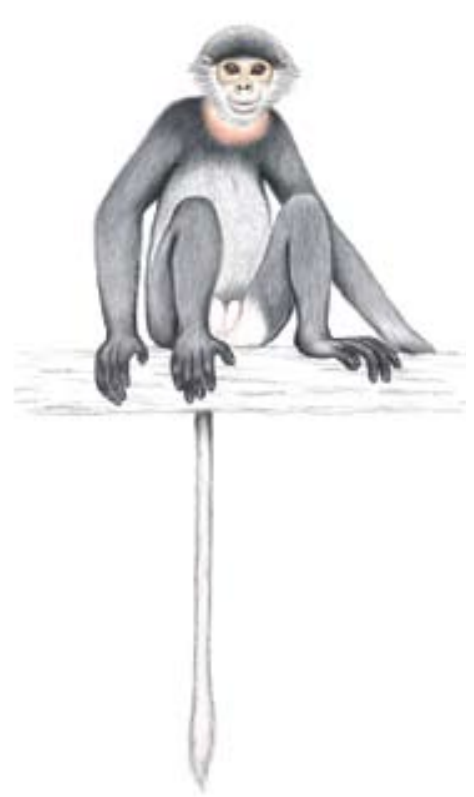

Grey-shanked Douc

Pygathrix cinerea

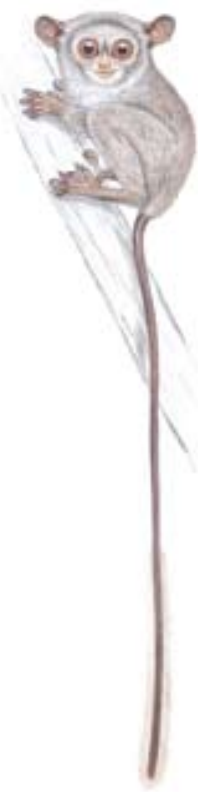

Siau Island Tarsier

Tarsius sp. 


\section{Asia, continued}

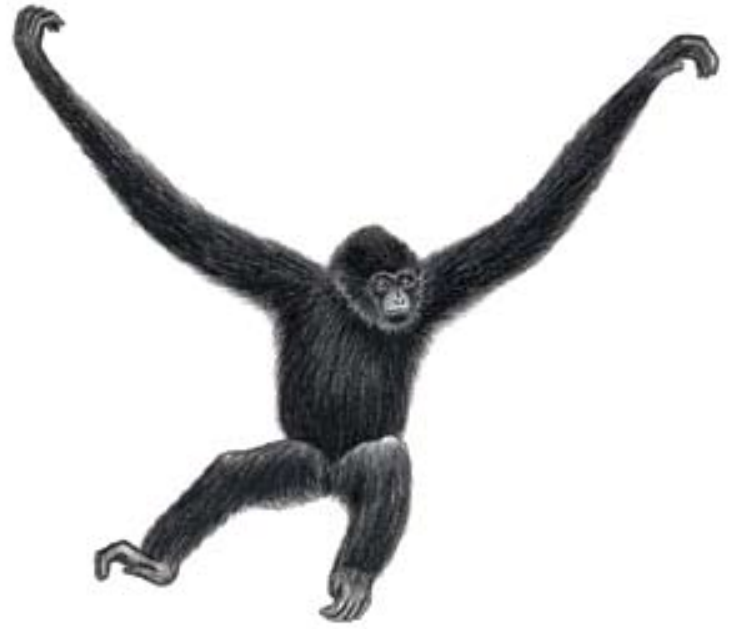

Hainan Black-crested Gibbon

Nomascus hainanus

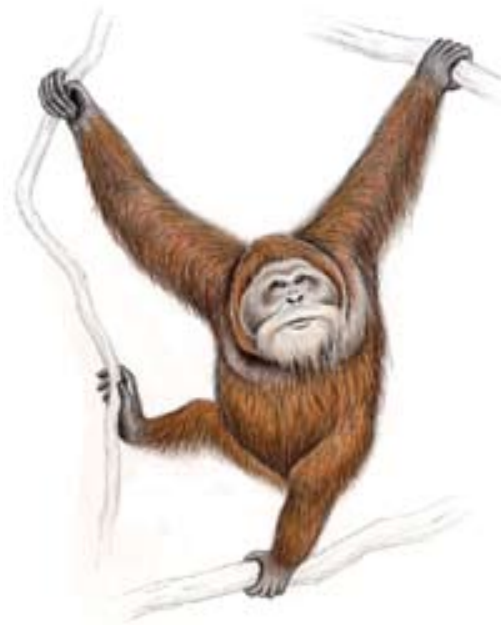

Sumatran Orangutan

Pongo abelii

All illustrations ${ }^{\circ}$ Conservation International/Stephen D. Nash. 